\title{
LOWER COLUMBIA RIVER SALMON BUSINESS PLAN FOR TERMINAL FISHERIES
}

Final Report

Prepared by:

Salmon For All

Astoria, OR

Prepared for:

\section{U. S. Department of Energy}

Bonneville Power Administration

Environment, Fish and Wildlife

P.O. Box 3621

Portland, OR 97208-362 1

Project Number 93-028

Contract Number DE-AC79-93BP39254 


\section{TABLE OF CONTENTS}

Section 1 - Introduction

Cover letter

Statement of Purpose

Glossary

Section 2 - Background

History/Overview of the Columbia River Salmon Fishery

Current Industry Product/Market Overview

Economic Profile

Section 3 - The Product

Unique Features of the Fishery and Product

Product Protection

Section 4 - Operations

Location and Geographic Issues

Quality Control Standards

Production/Harvest Control

Performance Audits

Section 5 - Organization

Management Options/Recommendations

Policy Issues

Section 6 - Marketing and Economics

Source of Funds

Executive Summary: Lower Columbia River/Youngs Bay Terminal Eisheries

Expansion Project Study for an Expanded Salmon Smolt Acclimation and

Release Program in the Lowe Columbia River/You PS Bav Area,

A Hans Radtke Report for Safmon for All, January \%!\%.

Market Potential

Financing Plan

Economic Contribution 
Section 1

\section{Introduction}

- Cover letter

- Statement of Purpose

- Glossary 


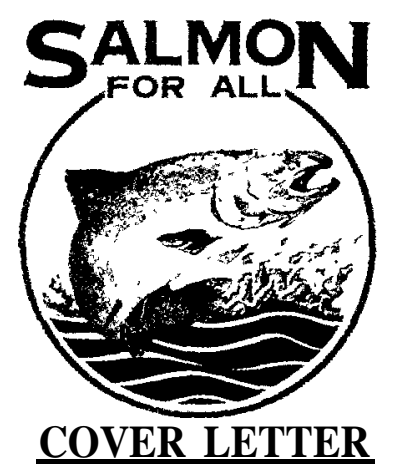

"Things are more like they are now than they have ever been." Anonymous

This confusing statement comes as close as any to summing up the current state of affairs with salmon, salmon recovery, and the ability of a once-vital commercial fishing industry to maintain its infrastructure. It has become increasingly difficult to fashion a future while looking through a kaleidoscope in which diverse, oft-changing biological, political, environmental, regulatory and business interests randomly tumble.

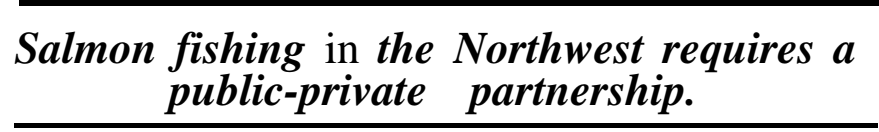

Salmon fishing in the Northwest requires a public-private partnership. The public through its decision-makers, agencies and laws states it will do all necessary to protect and preserve the valuable salmon resource. Based on that public commitment, many small private business men and women, and families, put together their own business plans for investing in boats, gear, and state-issued licenses and permits. All this is designed to return to the consuming public their salmon resource.

The public side of the partnership is broken. 60 years of promises, many well-intentioned but the most critical among them unkept, have taken their toll. Continuation of existing policies and procedures, some quite contradictory, most certainly mean the demise of both the salmon and the salmon harvest industry.

This Columbia River commercial gillnet salmon fishing industry, with over 140 years of documented history, is at a crossroads. Like a deer frozen in the headlights, the industry finds itself in the middle of a multiple intersection.

Flying by on all sides are the harvest impacts dictated by protection of Endangered Species Act (ESA) listed salmon, uncertainty about federal commitment to Mitchell Act funding, uncertainty about the political will to require fish passage improvements associated with the primarily federal operation of the Columbia/Snake River hydro-system, and uncertainty about the US/Canada negotiations and their ability to protect Columbia basin salmon. Add to these other speeding issues like uncertainty about continued natural ocean and drought conditions which do not support salmon, uncertainty about State Fish and Wildlife Agency funding, uncertainty about the politics of hatcheries and the role they may play in salmon recovery, and uncertainty about the role certain authorized federal agencies are to be allowed in protection and restoration of salmon. The reader may gain a sense of the frustration found in designing a future when there exists so many factors over which you have no control, and little input.

\section{The public side of the partnership is broken.}

What you are about to read is an effort by an industry to work within existing management and economic frameworks to gain more control over its destiny. 
The premises for this plan are seven-fold:

1) The Columbia region salmon fishing infrastructure is in delicate financial balance following years of little or no fishing. Help is needed.

2) A review of poll findings and public documents finds there is significant interest and commitment among the public and its agencies to recover salmon runs to harvestable levels. This implies that those who take salmon for economic sustenance are to be the beneficiaries, along with the recreational fishing community and the salmon consuming public whose tax dollars support salmon protection and production programs.

3) There is no overwhelming interest in closing down the productive Columbia basin salmon fisheries and unnecessarily eliminating the positive economic impacts these salmon harvest industries provide to families, communities and regions.

4) The salmon recovery plans of both the Northwest Power Planning Council (NPPC) and National Marine Fisheries Service (NMFS) call for the development of terminal fisheries as mitigation for lost harvest opportunity associated with protecting Snake River fish listed under the federal ESA.

5) Both plans lead the lower river fishing industry to believe it can co-exist with ESA constraints as long as it faces its future responsibly, with tenacity, with integrity, and with support for their own business and cultural heritage.

6) There will exist state and federal support of a plan that can show short and long range economic benefits to regional economies, while meeting the legal and biological demands surrounding current salmon harvest.

7) That federal and state support will be given to a plan which can demonstrate, uiing accepted economic indicators and factored using biological, environmental and pricing variables, that public financial participation represents an investment rather than a subsidy.

\section{....public financial participation represents an investment rather than a subsidy.}

The scope of this plan is to explore a variety of issues, concerns and ideas related to terminal fishery development. In some cases recommendations are made. In others, options are explored with an understanding that those designated as decision makers must make decisions following considerable discussion and reflection.

There are two specific recommendations designed to ensure the stability needed to get the program up and running.

1) Immediately establish an administrative structure through which implementation of this plan can be accomplished. The Columbia River Estuary and Study Task Force (CREST) is a viable solution for administrative oversight of this bi-state salmon production/harvest program. It is a "council of governments" organization made up of Oregon and Washington counties, cities, and ports of the lower river. It has a distinguished record for task accomplishment and research. It has been aggressive in pursuing funding and grants, while keeping its overhead low and its staffing lean. It could handle all the administrative and bureaucratic liaison work, while contracting with the Clatsop Economic Development Councils (CEDC) Salmon Enhancement Project for on-site, fish rearing leadership and expertise.

Clatsop County is also a strong candidate to administer Plan implementation. It is clear the County, because of its unflagging interest and support of the Youngs Bay Enhancement Project, will play a vital role no matter where administrative responsibility settles.

(For complete discussion, see "Organizations: Management Options", this report))

2) A five year funding commitment must be provided. This will provide staff stability for implementation of this plan. It also allows a full cycle of salmon production and return during which refinements can be made in the plan in order to reach maximum production and utilization of the salmon resource. From that will come an understanding of the continuing financial needs, if 
any, beyond that which the program will generate through fishing contributions and other sources. (For complete discussion, see Section 6.)

While this plan attempts to review all pertinent issues and concerns, it is acknowledged that additional, uncontemplated questions will arise. To that extent, this should be viewed as a living document subject to modifications as needed for program success.

No effort of this magnitude happens without significant work and input. A note of thanks is provided to the following individuals whose support and encouragement made this possible.

Steve Snith - Formerly of the Bonneville Power Administration, and currently with NMFS, Steve's interest in a future for the lower river fishery, and his knowledge of BPA priorities and funding made the contract that funded this effort possible.

Hobe Kytr - Formerly of the Columbia River Maritime Museum and currently with the Ilwaco Heritage Foundation, Hobe researched and authored the historical information found in the History Overview section, which provides a rich background against which to measure the importance of this plan's success. Regionally, Hobe has touched the lives of many in his capacity as educator, folklorist, musician, artist, historian, writer, spouse and father. He received his B.A. and Masters degrees at Reed College,

Hans Radtke and Shannon Davis - As distinguished and well known consultants, they created the myriad tables, graphs and options found in the marketing and economic section. Their analysis found here will be instrumental in gathering support for this project. It will also undoubtedly be used to support other programs encouraged by the success we expect to be associated with this project.

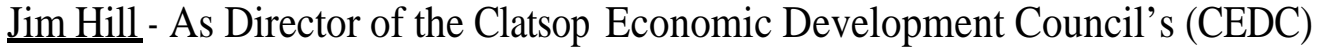
Salmon Enhancement Project in Youngs Bay, he has built a program used nationally as an example for cost-effective and biologically responsive production. Jim's expertise was invaluable in assigning costs for staffing, and net pen capital construction and maintenance. He also assisted instrumentally in developing a cost per smolt per net pen location.

Paul Hirose - A fisheries management specialist with the Oregon Department of Fish and Wildlife (ODF\&W), Paul has worked over two years gathering, evaluating and refining the biological data gathered to understand better the potential for terminal fisheries on the lower River. His work has been instrumental is determining the potential sites.

Marc Miller - As Hirose's counterpart with the Washington Department of Fish and Wildlife (WDF\&W), Marc has provided additional valuable information from both his personal experiences and the data gathered by and available through his agency.

Irene Martin - A noted historian and published author, Irene brought to this project much insight and editorial integrity. In addition, she brings her experience as a member of a fourth-generation Columbia River gillnet fishing family, from which she is recognized as an eloquent champion of the culture and heritage found in fishing families and their communities. 
Brenda Wall - Wife of a third-generation fisherman, a mother who home schools her children, and sought-after grant writer, Brenda poignantly provides the human side of the salmon story. She has produced some of the most riveting testimony provided before state and federal hearings/meetings in recent years. It came from her personal experience, and that of her neighbors, as they dealt with the stress brought on by reduced fishing income and difficult decision-making necessary to survive. She produced among others the Geographic Issues section.

Lisa Sudar - Spouse in a family fishing and fish buying business on the River, Lisa is a published writer. At the University of Washington she was an English and Linguistics major, graduating Cum Laude and Phi Beta Kappa. She directs the handbell choir at her church. Lisa's interest in research and writing produced several parts of this plan including the Unique Features section.

Doug Heater - As President of Salmon for All (SFA), Doug provided significant leadership in developing the atmosphere in which the grant was conceived and implemented. As Manager of Astoria's Bornstein Seafood Plant, he assisted in development of marketing section concepts and information.

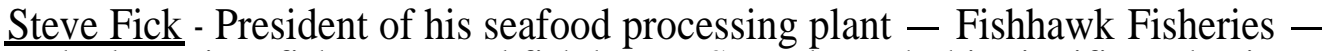
and a long time fisherman and fish buyer, Steve brought his significant business knowledge and acumen to the project. He, too, assisted in developing marketing strategies.

To all these fine folks, I extend my undying gratitude. Through this process they have become valued friends, an additional, unexpected and welcome blessing.

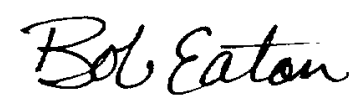

Bob Eaton

Project Coordinator

Bob Eaton - As Executive Director of Salmon for All, Bob was asked to coordinate this project. His background is in public administration and economic development. His experience dealing with salmon strategies, politics and regulations over the last eight years proved invaluable in overseeing the many facets of this diverse project. It was that diversity that led to the project taking several months longer than was originally projected. Bob is a published writer, soughtafter speaker whose leadership and advice is sought on a regional, national and international level. In partnership, he and the Salmon for All Board of Directors developed an organization that is used as an example of how to construct an effective fishing trade association. 


\section{STATEMENT OF PURPOSE}

Mission Statement: Sustain an economically viable commercial salmon fishery in the lower Columbia River, based on hatchery/net pen production and terminal area harvests, as a complement to feasible mainstem Columbia harvest opportunities.

Goal One: Maximize use of existing local, regional, state and federal resources through implementation of a coordinated, comprehensive lower Columbia River salmon production and harvest plan, creatively and effectively implemented by a cooperative administrative structure.

Goal Two: Demonstrate the economic viability of lower Columbia River net pen production and terminal fisheries through modeling and analysis of ranges for production, harvest, price, species, and other variables.

Goal Three: Maintain and enhance the economic benefits of commercial salmon harvest to families, communities and related businesses of the lower river region, the states of Oregon and Washington, and the Pacific Northwest.

Goal Four: Develop a harvest plan which makes lower river commercial fishing families, using their traditional vessels, the primary harvest beneficiaries of salmon produced under this business plan.

Goal Five: Develop commercial salmon harvest areas and techniques within the lower Columbia region that allow commercial salmon harvest with minimal impact on weak stocks.

Goal Six: Develop a fee structure, assessing those who participate in the harvest benefits of this plan, which could, over time, contribute to financial selfsustainability.

Goal Seven: Develop marketing philosophies, attitudes and strategies which uniquely place the salmon products of this plan in the highest strategic position within the market place. 


\section{GLOSSARY OF TERMS}

There may be terms found in this plan with which the reader is unfamiliar. To avoid confusion, the following definitions are provided. These may not follow the textbook definition, but do explain, in layman's terms, how they are used in this Plan.

Commercial fishery Those who harvest salmon using net (gillnette, in-river) or hook and line (troller, in-ocean) and whose catch goes through distribution to the consuming public.

Fingerling Small salmon still in the fresh water phase, traditionally defined as 15-269 days old.

Fisher The older, more traditional, expression for "fisherman". Because it is gender neutral, it is also currently the politically correct term.

Fishery An identifiable unit of harvesters. It may be quite large and generic - such as the "recreational saimon fishery" - or small and provincial such as the "Youngs Bay gillnet fishery".

Fishing industry Includes all who have some identified level of economic dependence on a fishery, and relates to both commercial and recreational fishing.

Fny Small salmon still in the fresh water phase which have begun to feed, traditionally defined as from 0-14 days old.

Harvest The catching of fish by recreational and commercial fishers.

Harvester One who catches fish.

Net pen A $20^{\prime} \times 20^{\prime} \times 10^{\prime}$ floating device made of plastic pipe from which tight mesh netting is attached and suspended into the water. Fish are confined within the net where they can be fed and cared for before being released.

Product For the purposes of this report, net pen raised salmon returning as adult fish.

Recreational fishery Those who catch, or those who guide others to catch, salmon on hook and line for personal enjoyment and use.

Release The process of freeing the salmon from their net pens so they can begin their journey to the ocean.

Salmon for All A non-profit trade association representing the lower Columbia River commercial gillnet salmon fishing families and the seafood processors. Including associate members, the Astoria-based organization has a membership list of 850 , about equally distributed between Oregon and Washington. It was formed in 1958 to provide educational and legislative work on behalf of the industry.

Smolt A fingerling or yearling salmon beginning the physiological changes preparing it for salt water.

Terminal fishery The rearing of smolts and harvesting of adult fish confined to an area at or near the end of the fish's return migration (see next page for greater detail).

Yearling Small salmon still in the fresh water phase, traditionally defined as 270 or more days old. 


\section{TERMINAL FISHERY}

Since "terminal fishery" is a central part of this Business Plan, it is important the reader have an understanding of the concept, its principles and applications.

\section{RAISING FISH}

On an experimental basis over the last fifteen years, some juvenile salmon raised in conventional hatcheries have been transferred to other locations before being released to go to the sea. Youngs Bay, located off the Columbia River in Astoria, has been a successful site for this kind of transfer adn release. Net pens located in the Bay's waters become the home for these hatchery-raised fish which are transported from hatcheries using specially equipped trucks.

Depending on the species, these fish may remain in their net pen homes for as long as six months, or as little as two weeks. Research has shown that net pens offer an aquatic environment more closely resembling "natural"than a hatchery. In fact, raising salmon in net pens is the most cost effective way. There are no pumps to operate and no expensive facilities to maintain. Staffing is lean and effective. And it is food efficient since the marine environment naturally provides some feed.

\section{HARVESTING FISH}

In order to protect Snake River salmon listed under the federal Endangered Species Act (ESA), sport and commercial fishing on the Columbia River has been curtailed dramatically in recent years. Even though there are harvestable numbers of salmon, mostly hatchery raised, returning to the river system, conservative management plans provide little or no fishing time to catch them. Fish raised in and returning to hatcheries could be harvested if they went to areas where their catch would not have significant impact on the ESA listed salmon.

Studies have shown that fish residing in a location for a minimum of two weeks just before release (called acclimation) will return to that location rather than to the waters where they were hatched and reared.

By locating net pens in waters where fish may be safely harvested as returning adults, advantage can be taken of this homing instinct. These adult fish mill around the area in which their net pens are located creating unique and beneficial harvest opportunities for commercial and recreational fishing. 


\section{Section 2}

\section{Background}

- History/Overview of the Columbia River Salmon Fishery

- Current Industry

Product/Market

Overview

- Economic Profile 


\section{HISTORY AND OVERVIEW OF THE COLUMBIA RIVER SALMON FISHERY}

"Yet it seems to me it may be more helpful to the salmon to say straight out that the fish have allies, that they matter to someone, and they matter because we have so much at stake in terms of our fishing grounds and communities, our families, and our identities. Without them, we cease to exist. Without us, will they cease to exist?" (1)

Salmon fishing is the Pacific Northwest's oldest continuing industry, having origins which reach back well before the United States took possession of the old Oregon Country. As might be expected from the extent and longevity of the region's salmon fisheries, particularly those of the Columbia River, they have been extensively studied in the past. Several such studies are worthy of note at the outset of this discussion, providing the basis for a thorough grounding in the subject and eliminating the need for duplicating efforts better found in original sources.

Craig and Hacker on The History and Development of the Fisheries of the Columbia River, published in Bulletin 32 of the U.S. Bureau of Fisheries, 1940, (2) has long been acknowledged as the classic work in this field. The report was the result of scientific investigations financed by fees from leasing the Sand Island seining grounds from 1922 through 193 1. Craig and Hacker thoroughly cover all aspects of the river's fisheries from pre-history until 1938. Complete with numerous tables of catch statistics and analyses, the Craig and Hacker report frequently is cited as a primary source for information on the salmon fisheries of the Columbia River, sometimes, unfortunately, taken out of context from the meaning and intent of the original study. However, the original report by Joseph Craig and Robert Hacker as published in 1940 is a model of clarity and brevity, comprising a total of only 83 pages in length, and being remarkably free of jargon for a technical study. It is well worth reading in its entirety for the sense of the impending challenges facing the salmon fisheries at the outset of the dam-building era on the Columbia River. Craig and Hacker outline with considerable accuracy the major issues that continue to affect the river's salmonid species and the fisheries dependent on them to this day.

Our primary concern in this discussion is to place the in-river, non-treaty commercial fishery of the Columbia River in such context that it may be properly understood as part of a rational management plan for the Columbia River system. No better overview of the subject is likely to be found than in Irene Martin's recent book on the gillnet fishery of the Columbia River, Legacy and

Testament: The Story of the Columbia River Gillnetters. With the happy combination of advanced credentials as a researcher and archivist, and unlimited access afforded by being a member of a fourth-generation Columbia River fishing family, Irene Martin possesses unusual qualifications for the task set forth in this remarkable book. Legacy and Testament goes beyond historical development to explore philosophical and natural resource issues at the heart of whether the gillnet fishery has a legitimate place for the future under a regimen of weak stock management on the Columbia River system.

"Work Is 0 ur Joy: The Story of the Columbia River Gillnetter"(3) is a half-hour audio-visual production available on VHS which provides a brief social history of the commercial salmon fishery of the Columbia River. The production is based on an extensive series of oral history interviews conducted under the auspices of Oregon Sea Grant and housed in the Columbia River Maritime Museum, Astoria. "Work Is $\mathbf{O}$ ur Joy" has been honored with awards from the American Association for State and Local History and the National Federation of Independent Broadcasters, and is used as part of the program in marine anthropology at Rutgers University. Finally, cultural anthropologist Courtland Smith of Oregon State University is the author of several works on the Columbia River salmon fishery, including Fish or Cut Bait, O regon Fish Fights, and Salmon Fishers of the Columbia. (4) The last of these, in particular, is widely available in library collections, though it has been received with mixed reviews by other scholars of the fishery and by the fishermen themselves. 


\section{The World's Greatest Salmon Stream}

The historic viability of the salmon fishery on the Columbia River may be seen from the fact that the river's native salmon runs supported an ancient and intensive Indian fishery for thousands of years prior to contact with Euro-Americans. The Long Narrows of the Columbia was the oldest continuously inhabited site in North America before being flooded by The Dalles Dam.

Archaeological evidence of human habitation at The Dalles goes back nearly 10,000 years. The evidence further suggests the Early stage culture at this site was dependent on fish by 7,500 years before the present. The Late stage, believed to be a salmon-fishing culture with continuity into the historical period, began more than 6,000 years ago. (5)

It is important in understanding the extent of the native fishery on the Columbia River to realize that it had strong commercial as well as ritual and sustenance components. Lewis and Clark and other early observers in the region noted an extensive trade in dried and pounded salmon, packed in baskets lined with fish skin. Dried-pounded salmon was a standard item in the regional trade network, which provided winter sustenance to peoples far removed from the Columbia River, both up and down the coast, and as far away as the Great Plains.

Craig and Hacker's study cites population figures for the Indians of the Columbia basin during the nineteenth century derived from Charles Henry Carey, History of O regon, 1922. Carey acknowledged the rapid decrease in the region's native populations following the introduction of European diseases. However, his figures are largely based on Lewis and Clark, who came to the region after the population declines had begun. There is good reason to suspect that 50,000 people in the region prior to contact may in fact be considerably low. . Based on ethnographic observations of dietary habits in the region, Craig and Hacker reach the following conclusion:

Therefore it appears to be well within the realms of possibility that these Indians had an average per capita consumption of salmon of 1 pound per day during the entire year. If such were the case, and the population were 50,000 people, their annual salmon catch would have been about 18,000,000 pounds per year. During 1933, the commercial catch of all species of salmon and steelhead trout on the Columbia River was approximately 26,000,000 pounds; therefore, it is evident that in primitive times the Indians may well have taken an annual catch that was a very significant proportion of the commercial catch today.

Even though the primitive Indian catch might have been of some such magnitude as that estimated above, it did not represent as great a proportional strain on the spawning population as its relationship to the present catch would indicate. That is because it must be remembered that under present conditions many miles of spawning streams have been cut off by dams so that they are no longer available to the migratory fish, that irrigation diversions take an enormous toll of the young migrants when they are on their way to the sea, and that pollution and other changed conditions have made many streams less suitable for salmon. (6)

In the context of their discussion, the meaning of Craig and Hacker's conclusions about the precontact Indian fishery are quite clear: that the salmon runs of the Columbia were fished intensively by Native Americans for centuries at levels approaching the catch of the post-contact industrial fishery, and that this intensive fishery was prosecuted without apparent damage to the river's salmon runs because such intensive harvest was not accompanied by environmental degradation. This is a conclusion that is often overlooked in reviews of the Columbia River fishery. Further, there is a certain probability that the rapid drop in post-contact native populations in portions of the Columbia basin during the nineteenth century (7) may well have resulted in elevated salmon populations by the time of the early non-native commercial and industrial fishery. Though it does not justify the excesses and waste characteristic of the early non-native commercial fishery, the salmon canning boom of the 1860s through the 1880s was very possibly coincidental with rebounding salmonid populations due to the dramatic reduction in the Indian fishery during the preceding decades. The salmon runs of the Columbia River during this period were not boundless, but they probably were larger than normal. 
That the Indian fishery also had a vital and important ritual aspect is well known, and, of course, continues into the present in the spiritual relationship with the salmon practiced by Indian peoples today and recognized under treaty obligations. The ethno-historical record is filled with numerous accounts of elaborate first salmon ceremonies throughout the Northwest Coast. Specified rituals varied not only from village to village and among language and ethnic groups, but often by specific runs fished within a given locale as well. Ability to make clear distinction between separate subspecies among salmon populations was also reflected in the multiplicity of names for different salmon runs in native languages of the Columbia basin.

The period identified by Craig and Hacker as transitional between the pre-contact Indian fishery and the modern commercial and industrial fishery, which supplanted it in the second half of the nineteenth century, is in many ways more closely associated with the earlier period than with thelater. For several decades, beginning with the Hudson's Bay Company saltery at Pillar Rock, which was in place by the early 1830s, and later joined by such operations as P. J. McGowan near Chinook Point, salted salmon was introduced with mixed results to world markets. The salted product was favorably received, but had a tendency to spoil on shipboard on the way to market. Harvest operations during this transitional period were largely limited to native fishers, in part because of the widespread fear among Indian peoples that taking salmon without proper attention to taboos and rituals handed down over the generations would have disastrous results. Early efforts by American entrepreneurs to introduce non-native fishers to the region, notably Nathaniel Wyeth in 1834, were successfully resisted by the Hudson's Bay Company and their Indian suppliers. It was only after the lower Columbia region's Indian populations were decimated by European diseases and American settlers began pouring into the region across the Oregon Trail that non-native fishers entered the nascent commercial fishery of the Columbia River. The first documented use of a drift gillnet by white fishers on the Columbia River was by Hodgkins and Sanders at Oak Point in 1853, using a net brought to the Columbia from New England.

\section{The Modern Commercial Fishery}

The "modern" era of the commercial salmon fishery on the Columbia River really begins with the introduction of the canning process to the region by Hapgood and Hume in 1866. Founders of the first salmon cannery in the United States, Hapgood and Hume first located on the Sacramento River in 1864, but soon decided to relocate to the Columbia, where they judged the supply of prime quality salmon for the new canning process would be more reliable. Modern conjecture has associated siltation of spawning grounds on tributaries of the Sacramento due to hydraulic mining in the Sierras during this period as the likely cause of the pioneer canners' decision to come north. Settling on a location at Eagle Cliff, Washington Territory, in 1866, Hapgood and Hume employed two boats and nets and put up a pack of 4,000 cases, each containing 48 tall one-pound cans. From this humble beginning there ensued what literally amounted to a salmon rush on the Columbia River. By 1883, there were no less than 39 canneries on the Columbia River, 22 of which were in Astoria alone. During that year, the Columbia River canneries employed 3,400 fishermen and 1,700 boats, and put up a pack of nearly 630,000 cases.

This early period of the salmon canning industry is often characterized as one of greed and waste, of overharvest of the resource accompanied by rapidly diminishing runs. While there is some truth to this view, it can be overstated to the point of obscuring other valuable lessons to be learned from the record of this era. It would probably be more accurate to view the early boom-and-bust period of the salmon canning industry as over-capitalized and under-regulated. Immense fortunes were won and lost during these years by capital investment in the canning industry. New canneries went up almost overnight, and passed out of use just as quickly. There were too many canneries and too many boats to sustain a viable fishery. Even so, competition to get rich on marginal investments was so intense that many canneries employed more fishermen to catch more fish than could reasonably be processed before they began to spoil. Waste was the order of the day, but it is more properly attributable to the canneries than to the fishermen.

During the early period of the commercial fishery on the Columbia River, the canneries owned the boats and nets, and the majority of fishermen were transient workers from California and other 
parts of the West, often with little or no fishing experience before being employed on the Columbia. As time progressed, however, these seasonal workers increasingly tended to be emigrants from the fishing districts of Finland, Scandinavia, and the Mediterranean countries. As soon as they could afford it, emigrant fishermen sent for their families and began the basis for the communities with strong ethnic identities which still exist on the lower Columbia. This change to stable, permanent communities of fishing families had important influences on how the fishery changed and developed over the decades following the 1880s. Not the least of these changes were the beginnings of fishermen's benevolent societies and the Columbia River Fishermen's Protective Union, which had its origins in the 1870s and was formally organized under the American Federation of Labor in 1886. (8) The focus of early efforts to organize gillnet fishermen on the Columbia River seems to have been threefold: to clear the fishing grounds and to make it easier and safer to fish on the Columbia River; to be a bargaining agent with the canneries; and to provide a positive influence for the improvement of moral character in the community at large. The C.R.F.P.U. confined its activities to organizing on the Columbia River and only among gillnet fishermen, but did so in both Oregon and Washington and without regard to ethnic background. Thus the river itself and the fishery it supported became the basis for the forging of a uniquely traditional American community with a strong regional identity.

One development characteristic of an evolving ethic among the fishermen of the Columbia River was the founding of the Union Fishermans Co-operative Packing Company in the latter part of the 1890s. Following the Panic of 1893 and the general economic downturn which followed, fishermen had gone on strike in 1896 over the price paid by canneries for fish delivered at the dock. The National Guard was called in, and fishermen were forced to go back to work, whereupon the price per pound was cut and a limit placed on each boat.

After we patiently and faithfully endured the struggle of the strike, we ran out of food. Then we were forced to go fishing at the price the canneries offered - $4 \varnothing$ a pound. But when the canneries had got us fishing - there was a lot of fish in the river - they lowered the price almost immediately to $2 \notin$ a pound and set a limit of 500 pounds per boat. Some gave up fishing, and others fished at the set price. After deliberations among fishermen, the unanimous decision was: "Let's build our own cannery!"

In our family there is a saying, "Beginning is always difficult; work is our joy; and industry overcomes bad luck." (9)

Compared to the giants of the industry, such as the Columbia River Packers Association, organized in 1899, which dominated the salmon canning business on the Columbia River for decades, Union Fisher-mans Co-operative Packing Company was not a large player in the game, but it did have a strong influence on attitudes within the community. Among the conditions of the "private" canneries that gillnet fishermen on the Columbia found most objectionable were the greed and waste of the early decades of the packing industry.

In the early years, the private canneries, a lot of them, had built up their own fleet of boats and their own nets, and they loaned them - they were just loaded with free boats and gear. Everybody wanted to get enough fish to be ahead of the other packers.... And the time came when that was so disorganized over there that they contracted with more fishermen than they could handle during a big run.

And Jon Bell told of times, too, when the fishermen came in there, honestly expecting to make a nice little delivery, and they couldn't even deliver their fish. God, that was just murderous, practically.

- Bill Puustinen, longtime Columbia River gillnetter, who fished for Union Fishermans Co-operative Packing Company (10)

One of the clear conclusions which appears from the record of catch statistics during latter decades 
of the nineteenth century is that an industrial fishery regulated only by the desire for profit quickly began to deplete the resource upon which the industry depended. At first only the premium spring and summer chinook were packed, but as returns diminished, coho, blueback, chum and other species were targeted. Thus, while the catch and resulting pack remained high through the beginning decades of the twentieth century, the numbers reflect a much broader sampling of the salmonid populations native to the river. Recognition of diminishing returns caused some packers to leave the business, others to relocate, typified by Robert Hume's move to the Rogue River in the 1890s, and still others to buy out the competition. The formation of the Columbia River Packers Association in 1899 is the primary example of this last strategy, in which the major packers on the river consolidated, shutting down numerous smaller competitors in the process. Diminishing returns also were the primary motivation behind the first attempts at hatchery supplementation, which began as early as the 1870s, though no particular degree of success was shown in these programs until some twenty years later. The oldest established canneries on the Columbia River date from the 1890s, at Bonneville and Chinook, respectively. Another clear and important conclusion from the records of this era is often overlooked - that the specter of diminishing salmon runs very early on elicited efforts to regulate the fishery so as to provide for adequate spawning escapement. Washington Territory established the first gear regulation in 1866, the same year Hapgood and Hume's cannery was founded at Eagle Cliff. Eleven years later, closed fishing periods were instituted. In 1878, the Oregon Fish Commission was established and passed its first gear regulations. The Washington Department of Fisheries and Game was established in 1890. (11) These were the beginnings of a new era on the Columbia River; one in which the salmon fishery was increasingly managed by public agencies for the stated purpose of conservation of the resource. This particularly has been the case during the twentieth century. However, as the present century progressed, it began to be clear that the pressures of intensive harvest were not the only factors affecting survival of salmon populations on the Columbia River. But given the complexity of dealing with the multiplicity of other issues involved, regulation of the fishery remained the only tool available for dealing with the problem of declining salmon runs.

\section{A Regulated Fishery}

Formation of state fish authorities was only the beginning of agency management of the fishery. Joint management of the fishery by Oregon and Washington began in 1899. The two state legislatures acted together to form the Columbia River Compact in 1915. Added to agency regulation in the decades that followed were legislative and initiative petition efforts to limit the types of gear used in the fishery. At the turn of the century, salmon runs were intercepted not only with drift gillnets, but also with set nets, pound traps, haul seines (used with horses after about 1895), whip seines, and, on the upper Columbia, fish wheels. For a brief period during the teens, purse seiners from Puget Sound fished the Columbia. Theirs was the first gear to be eliminated by legislation, in 1917. Whip seines followed in 1923, which was also the first year that fish buyers in Oregon had to report directly to the state.

Regulations imposed on fishing in the river were viewed by some fishermen as heavy handed. In 1912, a troll fishery off the coast was initiated. The rationale for the troll fishery has often been associated with technological advances, particularly the introduction of the marine gas engine to the Columbia River fishing fleet, which was occurring at about this same time. While there is no question that troll fishing was made possible by the gas engine, dissatisfaction with fishing restrictions on the river was also a prime motivation for some fishermen to take their boats beyond the jurisdictions of the state regulatory agencies. Xenophobic attitudes fostered by the First World War accelerated this trend towards an offshore fishery. Alien exclusion acts in Oregon and Washington during the Twenties required immigrant fishermen to acquire citizenship papers to participate in the fishery. Many immigrant fishermen reacted by rigging their gillnet boats with trolling gear and fishing beyond the three-mile limit.

Perhaps the most dramatic changes in the commercial fishery of the Columbia River occurred in the political arena. Initiative petition efforts to restrict and/or eliminate certain types of gear began in the early part of the twentieth century and have continued into the present. Fish wheels were 
prohibited in Oregon in 1927. A more sweeping restriction was passed in Washington in 1934, eliminating haul seines, pound traps and set nets. A similar measure passed in Oregon in 1949. Steelhead were restricted from commercial catch or sale in Washington in 1934, but not in Oregon until four decades later. Though arguments for these various restrictions usually claimed they were conservation measures, viewed objectively, each clearly was motivated by user groups wanting increased allocations from a fishery that was under heavy pressure not just from harvest but also from development throughout the Columbia basin. This trend has continued into the present, with repeated efforts by sports fishing groups to eliminate competition from commercial gear, primarily gillnets, despite the fact that catch statistics show that neither the non-native commercial or sports fishery in recent years have met allowed allocations. (12)

Methods used to regulate the fishery have taken a number of forms over the years. As previously mentioned, limits on seasons and restrictions on allowable gear began quite as early as the 1870s. Recognition that certain runs were being impacted prompted the agencies to close certain seasons and to shift the timing of others. The failure of these management techniques on the Columbia River to protect weakened stocks has been evident for a number of years, but the fundamental reason for that failure has been considerably muddied in the process.

One view of the difficulties encountered by the agencies charged with regulating the Columbia River fishery is that their essential failure to protect salmon has as much do with what was not being regulated as what was. This point was clearly made in the Craig and Hacker report nearly sixty years ago. While fully recognizing the impact of the development of an industrial fishery on the Columbia River, Craig and Hacker repeatedly point out that harvest is but one of a number of factors affecting fish populations, and that regulating harvest alone would do little to protect spawning populations. Their conclusions were made quite pointedly in the summary which follows the main body of the report (emphasis added):

19. Adequate spawning escapements and favorable conditions on the spawning grounds are necessary for the continued productiveness of the salmon fisheries. Originally the Columbia Basin provided a highly suitable habitat, but settlement and development of the area have greatly modified this condition.

\begin{abstract}
20. Settlement of the Columbia Basin began early in the nineteenth century. The arrival of missionaries, fur traders, farmers, and miners, taking place in the early part of the century, was the beginning of the movement. Later, construction of the transcontinental railroads and the development of the lumber industry caused large additions. Lumbering, mining, hydroelectric power developments, irrigation, and flood-control projects have all been undertaken in the Columbia Basin and have all adversely affected the spawning and rearing habitats of the salmon to some extent.
\end{abstract}

21. The fish populations of the Columbia River have been decimated by the development of the commercial fisheries, the deleterious effects of the various industries which have developed in the basin, and by the direct loss of spawning areas.

An adequate number of spawners can be provided by regulating the fishery. The problem of providing a suitable habitat for the adult spawners, the eggs, and the young is more complex and can be solved only by coordinated planning and adequate fish protection at projects which interfere with proper conditions in regard to fish life. (13)

The irony of the Craig and Hacker report, of course, is that it was published concurrently with the construction of the first federal hydropower projects on the Columbia River system. Bonneville Dam, completed in 1938, included adult fish passage facilities only after public outcry which included a petition drive initiated by members of the Columbia River Fishermen's Protective Union. Grand Coulee Dam, completed in 1941, was built without fish passage, effectively eliminating the upper third of the Columbia River as spawning habitat. Despite well-intended efforts by fishery biologists to transfer the upper river runs to tributaries of the Columbia below 
Grand Coulee, and to substitute hatchery rearing for natural spawning habitat, little was known at the time about the life cycles of some of the species that once spawned in the upper reaches of the river. Most notably, the completion of Grand Coulee Dam doomed the magnificent run of giant Royal chinook which for thousand of years had spawned above upper Arrow Lake in British Columbia. Known colloquially as "June Hogs", these fish averaged over fifty pounds, and had been the mainstay of the Columbia River commercial fishery for many years. The June Hogs disappeared forever in the late 1940s.

Clouding the issue of fisheries regulation on the Columbia River is the bewildering array of environmental changes to the Columbia River system during the past century for which there have not been coordinated management efforts. In addition, scientists have begun to recognize periodic changes in ocean conditions that have an adverse effect on salmonid populations at sea, but which as yet are poorly understood. Taken together, blocked passage and habitat degradation have had an enormous impact on Columbia River salmon runs, both directly and indirectly, but it has been far easier to point to the connection between numbers of salmon harvested and diminishing runs overall than to deal with more complex underlying problems with the way Columbia Basin system has been managed as a whole.

Reduction of harvest was the management agencies' strategy to compensate for inter-dam and other salmon mortalities. The very real issue of overfishing that was so evident in the nineteenth and early twentieth centuries has now been transformed into a term used to mask the results of environmental degradation and hydroelectric development. In fairness to the agencies, it must be said that, for the most part, they did not have the authority to address the most critical issues. Now that the crisis is apparent to anyone who reads a newspaper, negative stereotyping of fishermen is a shield to deflect criticism from those who share a responsibility for habitat loss and damage to salmon runs. (14)

It would seem both obvious and reasonable to suggest a comparison to other well-documented fisheries where regulating harvest for adequate escapement has not been accompanied by the sort of environmental degradation witnessed on the Columbia River. Perhaps the clearest case is that of the fishery in Bristol Bay, Alaska, where red salmon have been harvested intensively by gillnetters in the bay for well over a century. The Bristol Bay fishery has been managed with a variety of regulations over the decades to ensure adequate spawning escapement. In clear contrast to the collapse of the Columbia River fishery, record runs have returned to Bristol Bay several times in recent years. A record 39.3 million prime quality red salmon were harvested by Bristol Bay gillnetters in 1993, topping the previous record set ten years before.

The failure of fishery regulations to protect Columbia River salmon runs is now widely known. Yet, the frequent charge that "overharvest" is the principal cause of declining runs would seem to ignore the evidence that suggests other causes have played possibly an even greater role. For their part, fisheries managers, faced with the hard evidence of steady declines, have had no illusions about their inability to protect heavily impacted runs despite their best efforts to provide adequate escapement from harvest related mortality. With reference to the endangered upriver spring Chinook runs, Status Report: Columbia River Fisheries, 1938-1993 from the Oregon and Washington Departments of Fish and Wildlife states that: "Even with no commercial fishing since 1977, the upriver run has met escapement goals only twice, in 1978 and 1986."

Even though upriver spring chinook harvest rates have been reduced from the 1938-73 average of 55\% to the 1974-93 average of 10\% and escapement has returned to pre- 1974 levels, these stocks no longer provide a harvestable surplus. Factors other than harvest and escapement have been affecting stock recruitment since the 1970s. (15)

This situation was clearly foretold in the analyses of the Craig and Hacker report in 1940. Adequate spawning escapement must be provided for the maintenance of a viable fishery. But that alone will not protect the stocks upon which the fishery depends. 
The importance of proper fisheries regulations and adequate spawning escapement cannot be overemphasized, and certainly the disastrous effects of depletion caused by overfishing are well known. It is also evident that unless an adequate broodstock is maintained in any fishery the industry will not be able to continue at a normal level of production. But, in considering the problems of conservation connected with anadromous fishes in general, and salmon and steelhead trout in particular, a second important question - that of maintenance of suitable spawning and nursery grounds - arises. No matter how large an escapement of anadromous fishes may be allowed, the returns from that escapement will not be satisfactory unless the spawners have free access to spawning grounds adequate in size and suitable for the deposition and development of their eggs, and to streams which provide proper food, chemical, and temperature conditions for the young fish, and down which those young fish can migrate safely to the sea without the hazards of diversions or obstructions. (16)

As has been noted elsewhere, most recently in the Snake River Recovery Team: Final Recommendations to the National Marine Fisheries Service, May 1994, and the Columbia River Basin Fish and Wildlife Program of the Northwest Power Planning Council, December 1994, the lack of coordinated planning throughout the Columbia River basin has played a primary role in bringing the present situation to pass. If salmon recovery efforts are to have any hope of succeeding, such coordinated planning on system-wide basis will be necessary in order to address the "other factors affecting stock recruitment" recognized by fishery managers and totally beyond their power to influence. This system-wide coordinated planning must recognize that harvest restrictions, which in the past have been the sole means available for protecting Columbia River salmon runs, will do absolutely nothing to save salmon runs on the brink of extinction due to factors, such as impeded passage and habitat degradation, which are completely unrelated to harvest and, therefore, are not affected by means traditionally used to regulate the fishery.

\section{The Columbia River Gillnet Fishery}

As previously outlined, Columbia River salmon once were harvested with a variety of different gear types. Fees derived from leasing the Sand Island seining grounds provided the funding for the U.S. Bureau of Fisheries study which resulted in the Craig and Hacker report of 1940. Craig and Hacker thoroughly detail all the various gear types in use on the river, to which source the reader is directed for complete information on the subject. In addition to gillnets, haul seines, whip seines, pound traps, set nets, and fish wheels were deployed by non-native fishers at various locations along the river. Haul seines tended to be located (though not exclusively so) on the Oregon side of the river. Pound traps were predominantly on the Washington side, especially in the heavily fished waters of Baker Bay, in the vicinity of Chinook, Washington. Fish wheels, as ingenious a method of harvest as ever invented, were deployed in the mid-Columbia, along the high-water side channels of the Cascades and The Dalles, where they intercepted primarily the summer runs of bluebacks (sockeye salmon). Native fishers on the mid-Columbia worked the falls and rapids of Celilo Falls and the Long Narrows with dipnets. At other locations set nets were used. Jump baskets were deployed at Kettle Falls on the upper Columbia, hence the derivation of the name. Seining grounds were controlled by the canneries, as were the fishwheels of the mid-Columbia region. Pound traps, though originally privately owned, came under the control of the canneries over time. The gillnet, on the other hand, was the gear of independent fishers. With so many different types of gear used in a geographically limited area, a certain amount of conflict as well as competition among user groups was inevitable, particularly as the twentieth century progressed and the effects of habitat degradation were added to the decades-long, intensive harvest of the spawning population. Arguments among user groups, aptly termed "fish fights," eventually spilled over into the political arena, where matters often were settled on the basis of initiative petitions.

Competition existed, not so much between the fishermen using these different types of gear, but between the gillnetters and the packers, who often controlled the seines, traps and wheels. Gillnetting was a relatively low cost technology, needing only an owner/operator, 
and perhaps one or two crew members. Seines, traps, and wheels were capital intensive, requiring large investments and big crews. Although there were individual trap and seine owners, the major canneries either purchased or leased the most productive grounds.

Each gear type had its strong points and weaknesses. Traps, seines, and wheels were stationary, set in a location where fish regularly appeared. If the fish did not show, more mobile gear - the gillnet - emerged as the winner. Freshet conditions could paralyze traps, seine, and wheel operations, while the gillnet was more flexible, able to fish in high-water conditions. As the numbers of fishermen in each type of fishery grew, competitive pressure in order to stay profitable increased. (17)

By the mid-twentieth century, drift gillnets were the only gear type still in use in the non-treaty commercial salmon fishery of the Columbia River. All the remaining types had been regulated out of existence, or eliminated at the polls. It should be noted, however, that the gillnet had always been the predominant gear type on the Columbia:

Drift gill nets are the most important gear type used on the Columbia in point of number of units employed and the size of catch produced. Approximately 59 percent of the total catch of salmon and steelhead made on the river from 1927 to 1934, inclusive, was made by this gear. (18)

During the same period, as noted in Table 6 of the Craig and Hacker report, "Average annual catch by species and gear, 1927 to 1934, inclusive," traps accounted for $21.1 \%$ and seines for another $15.3 \%$ of the total catch, as compared to the $59 \%$ of the catch accounted for by gillnets. (19) The remainder of the catch was divided between set nets, wheels, and dip nets. Examination of catch records from 1889 to 1934 yield similar percentages.

The Columbia River gillnet fishery is widely recognized among fishery experts as the most advanced fishery of its kind anywhere in the world. Set in the context of the salmon fisheries of the Pacific Coast, the Columbia River gillnet fishery has been the prototype for fisheries from California to Alaska. Boats and gear either originating on or specially adapted to the Columbia have had a tremendous influence on the development of fisheries up and down the coast. This can be seen perhaps most clearly in the development of the wooden salmon boat of the Pacific Coast, originally used under sail power and then adapted to motor. Though owing origins to prototypes built in San Francisco for the Sacramento fishery, (20) these boats were developed and perfected on the Columbia River and known everywhere as Columbia River boats, even when used as far afield as Bristol Bay, Alaska. The gillnet fishery of the Columbia River also has been marked by exceptional innovation in the use of gear, with a high degree of adaptation to specific grounds dictating multiple types of nets for different purposes. These then could be combined and adapted by individual fishermen to suit the specific place to be fished under specific conditions. Time, tide, flow conditions, mesh restrictions, and species sought are among a bewildering array of variables which go into the decision making process before the fisherman ever lays out his net. There is a saying on the Columbia: "Boats don't catch fish; nets do. And the best net man is the one with fish sense." Columbia River fishermen are known throughout the coast as good net men, and long have set the standard by which other fisheries are measured.

Adaptation to changing conditions has been the hallmark of the Columbia River gillnet fishery. This adaptation has not been confined simply to the technological development of boats and gear. Just as noteworthy is the high degree to which social adaptation to changing societal and economic conditions has marked the fishing community. From a very early date, gillnetters attempted to organize, partly in an effort to strengthen their bargaining power with the packers, but also to work for the common good on issues which affected the entire fishing community. As mentioned previously, the Columbia River Fishermen's Protective Union was formed in the 1870s and incorporated as part of the American Federation of Labor in 1886. One of the central issues around which gillnetters organized was clearing their grounds. The Columbia River drains a huge basin 
which through much of its range is covered by dense forests. Early maritime chroniclers mention the enormous size of trees and snags in the river. The snags and stumps which tore fishermen's nets thus were a natural part of the fishing environment on the-Columbia. The problem was no doubt exacerbated by the after-effects of widespread logging as the nineteenth century progressed and the twentieth century began. Tearing a net was not just an aggravation. Initially, nets were entirely hand-made and were in fact more valuable than the boats from which they were deployed . Even during the early decades of the salmon canning boom, when the canneries owned most of the boats and nets, a ruined net could mean a substantial debt to pay off at best, or perhaps even a ruined season. One way to deal with the problem was to organize to remove the snags.

As Irene Martin notes in Legacy and Testament: The Story of the Columbia River Gillnetters, the problem of snags was not limited to the Columbia River. On the Sacramento and on Willapa Bay, for instance, snags were seen as a convenient way to eliminate competition by novices. However, on the Columbia River conditions were such that snag removal became the obvious answer to a common problem facing groups of fishermen.

Only on the Columbia did the combination of long seasons, crowding, the need for extensive grounds, and high productivity combine to provide the impetus to make snag pulling a cost-effective means of improving access to salmon. The Columbia was so large and its salmon runs so immense and varied, that the fishery could be called a "gauntlet" fishery, with different communities along the river each taking a portion. In effect, it was possible for a fisherman to stay in one community for the various seasons and make a living, so "homesteading" a fishing area by clearing snags became a reasonable option. (21)

Early efforts at snag removal were associated with the grounds below Tongue Point during a period when floater nets were the only type of net being used. (Floater nets are so described because they fish near the surface.) As the twentieth century began and reliable marine gas engines were introduced to the fishery, another style of net came into use which demanded more rigorous snag removal. The diver net, leaded so that it fished the bottom of the river on the hard ebb (when the fish sound to get out of the current), and often hung with trammels and aprons into elaborate combinations of gear, prompted the formation of snag unions or drift associations in many locations on the river, primarily above Tongue Point. The effort and expense associated with locating the snags, hiring a hard-hat diver, and removing the logs and other debris from a specific fishing ground led to a system of "drift rights," which are well-defined in custom and usage, though not recognized under currently existing law. A specific fishing ground, or drift, so cleared and improved for the benefit of its "members" is said to be "closed." Drift rights basically define the right to fish in a specific locality within established rules of order, which govern how many members the association will take in, how opportunities to fish will be divided or rotated, and how expenses incurred while improving the grounds will be allocated. A drift right, much like a limited entry fishing permit, is a valuable commodity which can be bought, sold, inherited, or retired by a vote of the association members.

The subject of drift rights is extremely complex and has been written about at length from both the scholarly and legal viewpoints. For the purpose of this discussion, however, the key issues to note here are that the gillnet fishing communities of the Columbia River have developed an ongoing tradition of usage with extremely important implications for the future viability of a commercial salmon fishery on the Columbia River - especially during the foreseeable future when weak stock management will govern the decision making process for regulating the fishery, or even if there is to be a fishery at all. These evolving traditions represent a means by which Columbia River fishing communities have controlled access to the fishery, and also have cared for what has come to be known in the literature of fisheries management as "The Commons." The first of these is the more obvious, in that limiting entry tends to maximize opportunities for those who, by definition, have the right to fish in a given locale. This, fairly or not, can be directly attributed to purely selfmotivated interest. The second, though less obvious, is far more important, in that fishing 
communities and organizations not only have worked to improve their fishing grounds, but also have often been advocates for the fish themselves, including and especially during critical junctures when, collectively speaking, theirs was the only voice speaking on behalf of the salmon. This latter point is an important element in defining a future role for the traditional fishing communities of the Columbia River. Advocacy for salmon by commercial fishermen has taken many forms over the years. Perhaps the clearest example goes back to the early 1930s, when fishermen lobbied intensively for fish passage facilities at Bonneville Dam, without which there would be no upriver stocks of any kind today, endangered or otherwise. That Bonneville Dam might have been built without fish passage facilities is not now widely recognized, nor readily acknowledged by the Corps of Engineers. Corps' historian Willfred Willingham, in an account of the building of Bonneville Dam viewed by some as revisionist history, writes that fish passage facilities were included in an early stage of the planning process. (22) Anthony Netboy, on the other hand, counters that "When an alarmed fishing industry protested to the chief of the Corps, he is alleged to have said, 'We do not intend to play nursemaid to the fish.' (23) Setting aside differing interpretations of the historical data, there is no question that a petition campaign originating in the offices of the Columbia River Fisherman's Protective Union in Astoria and subsequently championed by Merle Chessman, the editor of The Daily Astorian-Evening Budget, was mounted to pressure for fish passage at Bonneville Dam when the issue was far from certain. It is also evident that, when first conceived, plans for fish passage were. rudimentary at best, and the degree to which they would be successful was legitimately in doubt. (24)

Fishing organizations on the Columbia River also have served for decades as the keepers of the collective memory of fishery issues. Just as the Indian peoples of the lower Columbia once made fine distinctions between individual sub-species of salmon in the river, long experience has taught their modem counterparts among commercial fishermen to make similar kinds of fine distinctions, including habits, timing, and special characteristics of runs sometimes lumped together, but which in other ways are distinct and different. This degree of local knowledge, combined with years of following regulatory issues and agency decisions, has made fishermen repositories of the larger context of contributing factors which have led to the salmon crisis on the Columbia River. Eliminate the fishermen and the watchdog efforts by such fishing organizations as the Columbia River Fisherman's Protective Union, Northwest Gillnetters and Salmon For All, and the threat of eliminating what is left of the Columbia River salmon runs becomes all the more likely. In addition, other components of salmon recovery could be jeopardized. Authorization for Mitchell Act hatcheries is connected with the continued existence of the commercial fishery, as is the Pacific Salmon Treaty with Canada, which is currently being renegotiated and which has profound implications for interception of endangered Columbia River stocks at sea in Canadian waters.

It has been suggested that some of the means of harvest eliminated at the ballot box in past decades were far more selective than is gillnet technology. The Snake River Recovery Team recommendations to the National Marine Fisheries Service provide a good example:

Within the river, gears which had significant potential for selectively removing fish to provide for the most desirable spawning escapement (e.g., traps, fish wheels, and seines) were eliminated in favor of much less selective gear such as gillnets (Craig and Hacker 1940). (25)

In the early 1900s, most Columbia River salmon were harvested by gillnets, traps, fish wheels, beach seines, and dipnets (spears and gaffes were also used by tribal and other upstream fisheries) (Craig and Hacker 1940). Most of the large scale methods were capable of a high degree of selectivity; and, if modernized to protect fish during the retrieving operation, would permit live release with low mortality. The more efficient types were banned as pressure mounted to maximize employment. (26)

However, the text of Craig and Hacker does not support statements about the selectivity of traps, fish wheels and seines, as suggested above, nor do Bevan and company provide supporting 
evidence for their conclusions. Fish wheels were effective only in the rapids of the mid-Columbia, which have been eliminated by the lakes impounded behind the hydropower dams of the Columbia. Though some theoretical chance exists for live capture and release using seine technology, historical film footage and personal accounts by those who worked on seine crews reveals that chance to be slim indeed. Removal of thrashing salmon from the bunt of a seine filled with tons of panic stricken fish was not done in a manner consistent with concerns for their survival, nor did it afford much opportunity for close examination before a mortal blow or wound had been delivered. The gaff used in such circumstances was hardly a reliable means for "live release with low mortality." Fish traps, sometimes used as a supplement to hatchery operations, probably offer the greatest possibility for live release of all these methods, but raise other significant issues of no small import. Why is it, then, that of all the gear types used on the Columbia River gillnetting remained and other means of harvest were eliminated?

One idea is simply to eliminate gillnetting on the Columbia River and come up with an alternative means for harvesting healthy stocks that will not impact endangered stocks. No such means has as yet been developed, although fish traps, currently illegal, appeal to some. Questions about who is to be allowed to use the new means of fishing access go unanswered. History tells us that gillnets were and are in use up and down the entire Pacific Coast and have outlived many other kinds of gear because they were adaptable, selective, efficient, manageable, and relatively cheap. Replacing them, with gear that meets those criteria will not be simple, nor will it be instant. The Columbia River gillnet has evolved for well over a century to meet changing environmental and technical demands. Fishing communities have also changed and adapted to meet those demands. Mandating new, as yet unknown gear, has repercussions on that community. (27)

Perhaps one reason that gillnetting has remained as the means of commercial harvest on the Columbia River is that fishery managers long have recognized that it is easily regulated. It is done in the open where it is readily monitored, yielding reliable catch records. The gear itself is highly adaptable, and its use amenable to controls over placement and timing. Under different configurations, it can be used to target different species at different times.

Some of the standard arguments for the elimination of gillnetting in fact reflect criticisms of fishery management techniques. These criticisms in turn are based on an evolving sense of what has hurt and what has helped protect the endangered salmonid populations of the Columbia River. For instance, some of the same concepts which in the past have guided hatchery supplementation efforts, and which we now understand to have been harmful to wild salmonid populations, have also guided harvest management techniques. By selecting stock for early or late-run characteristics and sorting by size, or some other outward characteristic deemed desirable at the time (instead of trying to match as closely as possible the overall diversity of the naturally spawning population), fishery biologists effectively promoted a narrow segment of the gene pool, thus reducing the chances of survival for the overall population. Harvest similarly has been managed in such a way that it often targeted relatively narrow segments of the gene pool, instead of in manner consistent with sampling smaller numbers of the broader population. This does not mean, however, that a rational management technique based on current understanding and using technology already available could not in fact address these inherent contradictions. The same factors of adaptability, selectivity, efficiency, manageability, and economy which in the past have made gillnets perhaps the most easily regulated component of Columbia River salmon harvest would still apply given a new regime of management controls under an evolving conceptual framework.

Moreover, the statement by the NMFS Snake River Recovery Team about gillnetting having survived because of mounting pressure to maximize employment is worth examining further. Since the waning days of the salmon canning boom on the lower Columbia, when the packers began to divest themselves of their fleets of boats and gear, Columbia River gillnetters have tended to be independent operators. The backbone of the Columbia River commercial fishing industry is the small, family-owned business. The suggestion to replace gillnetting with "large scale 
methods," with an as yet unproven capability for a "high degree of selectivity," would in effect be to throw over a system which benefits a diverse population with one which concentrates economic return in as yet undetermined, but decidedly fewer, hands. If the example of agribusiness displacing the family farm were to hold true, why should there be any confidence that these proposed large scale operations would have any greater concern for genetic diversity than has already been demonstrated by independent fishermen, who at this point have been fighting for the survival of Columbia River salmon for the past several decades?

\section{Economic and Societal Issues Concerning Lower Columbia Fisheries}

\section{One element that often' seems to be missing in current discussions of the relative cost} versus benefits of salmon recovery efforts on the Columbia River is that the commercial fishing industry, which is dependent on those salmon, has been a major part of the economies of communities along the lower river for well over a century. Discussion that is framed in terms of jobs versus salmon often fails to recognize the value of healthy salmon runs in providing jobs, especially in a region that has been hard hit economically in recent years.

Estimates of the dollar value of the Columbia River fisheries have been prepared a number of times, using a variety of assumptions and economic models. Despite the changing value of the dollar over time, such studies inescapably convey the tremendous importance of the economic contributions made by the Columbia River commercial salmon fishery to the economy as a whole, and especially to lower river communities. One of the most eloquently expressed of these assessments is found in the introductory remarks to the Craig and Hacker report:

It has been estimated that the value of the products of the Columbia River fisheries, plus that part of the output of the ocean fisheries which the Columbia River salmon contribute, is about $\$ 10,000,000$ annually when delivered to the consumer [in 1940 dollars]. This is probably a fair approximation of the Columbia River fisheries to the people at large. However, it should be remembered that the $\$ 10,000,000$ is merely the yearly income, or profit which has been taken each year for a great many years. Therefore it must be regarded in the same light as the interest from money invested, or dividends from stock purchased. The capital from which this income is derived is the population of the fish in the Columbia River and, as long as adequate breeding stocks are maintained, this annual profit may continue to be taken. Four percent annually is a fair return from a safe and conservative investment. So if we assume the $\$ 10,000,000$ annual income from the fisheries is the return from an investment paying at the rate of 4 percent per annum, the value of the capital invested, or, in this case, the population of fish in the Columbia River, is approximately $\$ 250,000,000$. (28)

Another view of the value of the Columbia River fishery comes from realizing how much has already been lost in real economic return to the communities of the lower Columbia because of the decline and/or loss of upriver salmon runs attributable wholly or in part to the operation of the Columbia River hydropower system. One such assessment was made in the 1940s to explain the necessity for emergency efforts to save the runs which formerly spawned in the "1,140 lineal miles of productive anadromous fish spawning and rearing streams" blocked to fish passage by the completion of Grand Coulee Dam. (29)

...Today Grand Coulee Dam has been completed to a height insurmountable to fish. The runs of fish are too valuable to be abandoned. It would take an $\$ 11,000,000$ investment yielding $4 \%$ annually without any depreciation to replace to the citizens of Washington and Oregon the annual yield now received from the runs affected by Grand Coulee Dam. (30)

The efforts to save the upper Columbia runs were conducted under incredible pressure to come up with a viable solution to this problem before it was too late. The methods used included trapping adult spawners at Rock Island Dam and transferring them to the Okanogan, Entiat, Methow and Wenatchee rivers, and, in some cases, substituting hatchery production for natural propagation. 
Unfortunately, these salvage efforts were only partially successful. The resulting losses were felt acutely by fishing communities and families along the lower Columbia.

A more recent economic analysis of the value of the Columbia River gillnet fishery was prepared by Hans Radtke and Shannon Davis for Salmon For All in 1994. The survey uses economic measurements in 1993 dollar values to assess non-Indian gillnet landings, economic values, and asset values for the period covering 1938 to 1993. Looking at the entire 55-year period, the annual landings averaged 7.7 million pounds, for an estimated economic impact of $\$ 22,900,000$. The same figures for the period extending from 1986 to 1993 yielded landings of 4.9 million pounds and an economic impact of $\$ 14,500,000$. Note that the study period begins concurrently with the completion of Bonneville Dam, and so covers the era of major darn-building on the Columbia and Snake Rivers. Even during a period marked by major declines in the fishery due substantially to factors unrelated to harvest and escapement, the gillnet fishery has contributed millions of dollars to the local economies of communities on the lower Columbia.

The annual revenues received by gillnetters from their catch and resulting expenditures create a flow of income to the regional economy. A reduction of that flow could result in an annual loss or economic impact of up to $\$ 22,900,000$ of income to the regional communities. Even if the fishermen were to be compensated for their potential loss, there is no guarantee that the new expenditure patterns will result in income to many people that were previously dependent on the gillnet fishery. A buy-out may result in fishermen moving to other geographic areas, thereby negatively affecting the fishing dependent communities. (31)

Also of tangible import to lower river communities is the issue of investment in infrastructure related to the gillnet fishery. Radtke and Davis give a dollar figure of $\$ 145,000$ for capital replacement costs per vessel related solely to gillnet boats and gear, which translates to $\$ 127,000,000$ - \$148,000,000 for the entire fleet. But in many ways, the investment in infrastructure is incalculable. Gillnetters operate as family-owned small businesses in what has become a highly specialized endeavor requiring far more than capital investments. Fishing families are not just invested in their boats and gear. They are invested through their local fishing organizations in long term maintenance and improvement of their fishing grounds. They are invested in a way of life that is meaningful beyond the economic returns it may (or may not) bring. Most gillnetters today are third, fourth and fifth generation descendants of immigrant groups who came to the Columbia River during the nineteenth century for the fishing. They belong to what is recognized by marine anthropologists as one of the last traditional communities of its kind in the U.S.

Further, these traditional fishing families of the lower Columbia are an integral part of the fabric of the communities in which they live up and down the river. Fish, once landed, go to the processors, who employ another segment of lower river communities. Gillnet boats require parts, maintenance and specialized gear. Marine suppliers are also substantially invested in the fishing industry. Fishing families, as part of many small communities on the river, buy food, fuel and clothing from local businesses. As taxpayers and parents, they support their local schools and attend their local churches. Thus it can be seen that investment in the fishing infrastructure of the lower Columbia involves a considerably broader cross-section of lower communities than just harvesters alone.

\section{Weak Stock Management and the Endangered Species Act}

The Columbia River system historically has supported four different species of Pacific salmon: chinook (O ncorhynchus tshaw ytscha), silver (0. kisutch), blueback (0. nerka), and chum (0. keta). Other anadromous species frequenting the Columbia's waters include steelhead trout, recently reclassified as belonging to the same family as Atlantic salmon, in addition to white and green sturgeon, shad, and smelt. One of the defining characteristics of the salmon fishery of the Columbia River, as well as its thorniest management problem, is that it is a mixed stock fishery. 
Fish of different sizes, species and subspecies enter the river and make their way towards their individual and separate spawning grounds at approximately the same time. This situation contributed to the complexity and uniqueness of the fishery as previously mentioned. However, at this juncture and for the foreseeable future, the fact that threatened and endangered stocks are present in the river at the same time as healthy stocks requires that those weakened stocks be protected, even at the expense of curtailing otherwise legitimate harvest of stocks belonging to runs present in sufficient numbers to warrant a fishery.

There are several reasons to believe that weak stock management will continue to be the guiding principle for protection of the Columbia River salmon for some time to come. Though the Endangered Species Act of 1973 came too late for some Columbia River salmon runs, in recent years the ESA has been cited as the principal rationale for protection of threatened and endangered Columbia River salmon stocks. Efforts to list certain specific runs under the ESA began in the latter part of the 1970s. Recognition of the role played by the massive federal hydropower system in bringing this situation to pass helped provide the impetus for the passage of the Northwest Power Planning Act of 1980, which was adopted in part to address the impact of the region's hydroelectric dams on fish and wildlife. The continuation of precipitous declines in the river's salmon and steelhead populations by 1990 focused national as well as regional attention on the problem. In November 1991, the National Marine Fisheries Service (NMFS) declared the Snake River sockeye (blueback) an endangered species. In April 1992, NMFS designated Snake River spring/summer and fall chinook as threatened species. These actions set in motion a series of actions required by the Endangered Species Act, which have included recovery plans from NMFS, as well as amendments to the Northwest Power Planning Council's Fish and Wildlife Program, which offers alternatives to the NMFS recovery plan. Official findings both by the Power Council and by NMFS were challenged in court, where Judge Marsh of the 9th Circuit Court ruled that their respective draft recovery plans were too heavily weighted in favor of the status quo and did not do enough to protect and mitigate fish and wildlife. Final proposed recommendations from the Power Council in December 1994 and NMFS in March 1995 created considerable political and legal controversy, which at this juncture is still being played out. Election of a new conservative Republican majority in the congressional elections of 1994 has prompted an attempt to dismantle several of the key provisions of the Endangered Species Act, specifically aimed at weakening protection for fish and wildlife. This effort, spearheaded by Washington Senator Slade Gorton with the support of major industrial concerns, is currently ongoing. The proposals now under discussion are cause for serious concern to Northwest fishing interests, who pointedly maintain that failure to protect and mitigate weakened Northwest salmon runs could result in possible elimination of jobs related to sport and commercial salmon fishing which provide personal income in California, Washington and Oregon of more than $\$ 1.2$ billion annually.

What will result from congressional action remains to be seen. However, there is ample reason to expect that weak stock management will continue to play a role in fishery regulation on the Columbia River for the foreseeable future, regardless of the outcome of amendments to the Endangered Species Act. Among other factors affecting regional strategies, the Northwest Power Planning Act of 1980 charged the Power Council it created to foster a system-wide approach towards management of the Columbia River basin. Among its responsibilities was instituting a fish and wildlife program to "protect, mitigate and enhance fish and wildlife affected by the development, operation and management" of Columbia River basin hydropower facilities, and to ensure the region "an adequate, efficient, economical and reliable power supply."

In addition, the region has other legal obligations that must be met regarding fish and wildlife, and which are complemented by the Council's program. These include: tribal treaty fishing rights, Executive Order tribal rights, salmon rebuilding obligations of the Pacific Salmon Treaty with Canada, and requirements of the federal Clean Water Act. These necessitate measures beyond those to remove listed salmon stocks from the Endangered Species list. (32) 
At present, the Power Council's amended fish and wildlife program and the NMFS recovery plan for Snake River listed stocks contain important and sometimes conflicting provisions for changes to the operation of the Columbia River system, including recommendations for altering streamflow to aid downstream migration of juvenile salmonids, structural changes to several mainstem and Snake River hydroelectric dams, installing screens on irrigation diversions, etc. Both have their supporters and detractors. The Power Council's plan relies more heavily on drawdowns to aid instream migration of juveniles through the gauntlet of hydroelectric dams and slackwater lakes on the Columbia-Snake River system in an effort to emulate the natural cycles of streamflow to which the fish adapted over thousands of years. The NMFS plan, on the other hand, relies more heavily on transport to get juvenile salmonids around the system of dams, which have been estimated to cause $77-96 \%$ of man-caused mortality for all juvenile salmon-trout migrating downstream from the upper and mid-basin.

Both plans also contain specific recommendations concerning harvest, both at sea and in the river itself. The Power Council plan calls for: developing harvest goals, escapement objectives and rebuilding schedules; improved and coordinated harvest management; voluntary harvest reduction for all fisheries; development of alternative harvest methods, live-catch technologies and knownstock fisheries; improvement of selective harvest technologies; expansion of terminal harvest fisheries; instituting measures to identify genetic stocks and to assess genetic implications of harvest; review of sport fishing regulations with regards to weakened stocks; better law enforcement and public education on impacts of illegal and wasteful fisheries; inclusion of Idaho and Indian tribes in the Columbia River Compact; unified reporting of harvest data; and speedy resolution of equity issues now impeding renegotiation of the Pacific Salmon Treaty with Canada. The NMFS plan is similar in some respects, calling for reduction of harvest rates and fishing capacity, license and boat buy-backs, and development of selective harvest gear and techniques. However, in a seeming contradiction, it also recommends phasing out gillnetting on the Columbia mainstem by 2002, while at the same time expanding the terminal fishery concept.

\section{Terminal Fisheries as a Co-Management Solution}

The terminal fishery concept as developed by the Clatsop Economic Development Council's Youngs Bay enhancement project offers perhaps the best interim solution for the maintenance of lower river economies historically allied with the commercial salmon fishing industry, while at the same time protecting weakened and endangered stocks from possible depletion by incidental harvest during a mixed stock fishery. By raising, acclimating and releasing excess hatchery smolts, such a terminal fishery specifically targets healthy and easily recognizable stocks. Fin clipping and coded wire nose-tags clearly identify fish reared by the project. By locating the project net pens in a side channel or bay not frequented by stocks of concern, the difficulties inherent in a mixed stock fishery are greatly minimized, if not eliminated altogether. Net pen rearing more closely imitates natural conditions than do standard hatchery methods, resulting in healthier smolts already making the transition to foraging for natural food by the time of their release, and therefore better acclimated for survival in the real world. This survivability factor has been shown over the past several years by comparatively high rates of return of mature salmon to Youngs Bay. The importance of this concept was brought home during the 1994 season when, out of all the millions of salmon raised by hatcheries in the Columbia basin, only those released by the Youngs Bay enhancement project were able to support a commercial (as well as a sport) fishery. More than 100 gillnetters harvested 57,800 coho salmon worth almost $\$ 400,000$ in exvessel value - the only bright spot in an otherwise gloomy year for lower river fishing families.

Begun in 1977, support for the Youngs Bay project has come from a number of different agencies and sources, including Clatsop County, the Port of Astoria, Oregon Department of Fish and Wildlife, and the Bonneville Power Administration. Commercial fishermen and fish buyers have provided voluntary contributions from catch proceeds to fund diversification of stocks raised by the project. Experiments with Willamette spring chinook have been under way the past several years in an attempt to develop a new, high quality spring fishery in an area of the lower estuary, which previously only supported coho and fall-run tule chinook. 
Early in 1995, Bonneville announced plans to provide funding for researching additional terminal fishery sites in the lower Columbia. Test fishing previously had identified several possibilities for expansion of terminal fisheries into additional areas off the main channel apparently not frequented by weakened and endangered upriver stocks on their migration through the lower river. (see Geographic Issue - Site Selection, this report)

Because mature fish returning to the area of the net pen essentially have nowhere else to go, they tend to mill around in a holding pattern in the general vicinity, providing opportunities for harvest well suited to existing gillnet technology. Further, since the gillnet fishery is already highly adapted and adaptable to conditions present in these locations, with a diversified infrastructure supporting numerous small family businesses, it is also a means of harvest that maximizes the benefits of harvest opportunity for lower river communities hard hit by fishing cutbacks in recent years.

The special combination of technological and social adaptation to the environs of the lower Columbia River which characterizes the gillnet fishery, and the high degree of interdependence of commercial fishing families with lower river economies, make the terminal gillnet fishery concept an intriguing possibility for maintaining the commercial fishery, and the communities dependent on it, during an era of weak stock management on the Columbia River. The possibilities raised by such a scenario go beyond merely retaining a familiar component of existing lower river communities. There is a sound theoretical basis for believing that involving commercial fishermen in the decision-making process concerning conservation and allocation issues as active partners and advocates for the salmon, as well as surrogate harvesters for the general public, as heretofore has been the case, would have far-reaching consequences for the long range prospects for genuine salmon recovery on the Columbia River. To explore this idea further, we need to examine an idea which has been much discussed in the literature of fisheries management over the past several decades: namely, the concept defined as the "tragedy of the commons." A lucid discussion of this subject is contained in an article by Courtland Smith, entitled, "Conservation and Allocation Decisions in Fishery Management." Doctor Smith defines the topic in the following manner:

The "tragedy of the commons" refers to the problem of heavily exploited fisheries with open access. Increasing numbers of people seeking an allocation from the fish stock threaten the fish stocks future productivity. Economic and social incentives to catch more fish cause overexploitation. (33)

The applicability of this concept to a number of different depleted fisheries is obvious to all. The question has been raised whether this concept, correctly applied, provides a way of understanding the salmon crisis on the Columbia River. At first blush it might seem so, and indeed that is the assumption that some who have contributed to habitat loss and damage to salmon runs unrelated to harvest would have us believe. But a closer examination of the situation on the Columbia River reveals a situation very different than in many other fisheries ruined by overexploitation. No one denies that overfishing did at one time occur on the Columbia River, particularly during the nineteenth and early twentieth centuries, and that it did in fact contribute to depletion of the resource. However, there is no direct evidence to suggest that any salmon runs disappeared during this period. On the other hand, the dramatic downturns in salmon populations of the Columbia River since about 1920 appear inescapably linked to factors such as habitat loss and the operation of an increasing number of hydroelectric dams, and these downturns have accelerated with the development of the Columbia basin. High dams built without fish passage are known to have extinguished several runs of Columbia River salmon. Other runs, particularly those of the Snake River, appear likely to follow unless major changes are made in the manner the system is operated, and soon. Hatcheries intended to supplement or replace populations lost to development now have muddled the gene pool, further compromising wild stocks, and appear incapable of mitigating the losses. This tragedy, perhaps not so common, is of a different order altogether. 
Critics of this view will no doubt respond that, in the face of other pressures, harvest has contributed to the depletion of weakened stocks needed for replenishing threatened and endangered runs. For this reason fishery managers have tried to balance allocation with the need for conservation; but at this juncture it appears unlikely that regulating the fishery has done much good for salmonid populations whose greatest threats have come from other sources. Though much attention over the years has been given the in-river, commercial gillnet fishery, the wild card of harvest regulation has always been that salmon and steelhead are wide-ranging anadromous species which are intercepted at sea far from their rivers of origin. The logic of harvesting mature salmon after they have entered their river of origin is inescapable, for which reason fishery managers have been reluctant to eliminate gillnetting on the Columbia River entirely. The regulatory response has been instead to shorten and/or eliminate seasons. Summer-run chinook have not been fished with gillnets in the Columbia River since 1964. Still their numbers have continued to decline. Other seasons have been shortened to the point where they can best be measured in numbers of hours. This manner of regulation, as a result, has increased the incentive to catch as many fish as possible in the time allotted, perhaps further contributing to the overall problem. Courtland Smith speaks of this phenomenon in the following manner:

A program giving conservation greater weight in decision making does nothing to change the incentive structure. The incentives producing a tragedy of the commons are still in place. For all users to feel the impact of their own actions on the whole, they must have some stake in the management of the resource. (34)

Doctor Smith also speaks of the answer to the unintended problems created by fishery regulations intended to promote conservation of the resource, but which do not involve fishermen as active partners in the decision making process:

To involve users in allocation decisions, councils need the authority to work with organizations of users established to prepare and implement management plans. The major role of the councils would then become the evaluation of how well they accomplish the objectives of the conservation plan. (35)

Such organizations of users may, in fact, already exist on the Columbia River. As previously outlined, social adaptation of the Columbia River gillnet fishery led to formation of associations to control access to the fishery and improve the grounds for the common benefit of the group. Given their active involvement in fishery issues over the years, it is no great stretch to think of these same fishermen as interested in the long-term preservation of the resource.

Combining fishery users into an organization that collectively makes allocations has the potential for reversing the incentive structure. If decisions are made outside the group of users, they are left feeling they are subject to someone else's authority and with no incentive to deal with collective effect of their actions. If allocation decisions are made by the group, this should create incentives for group members to make decisions that are in the long-run best interest of the fishery. (36)

Such an arrangement is referred to in the literature as co-management. Co-management schemes have been in place on the Columbia River for many years, but, as Irene Martin explains, nonnative fishermen have not been part of the arrangement:

Given the present situation, is there a way to resolve the dilemma of a fishery operated by custom among its participants, and one regulated by laws that may not respect custom? In the literature relating to TURFS [territorial use rights in fisheries, as defined by the United Nation Food and Agricultural Organization] the suggestion often arises of using TURFS as part of an overall management system. "Co-management" is the term used to describe a management partnership between government and user groups. Such co-management is already in place on the Columbia River between state, federal, and tribal agencies. 
However, as Norman Dale has pointed out, "Non-native fishermen have not been full partners in co-management and the accompanying social learning in Washington and Oregon." (37)

The expansion of terminal fisheries on the lower river provides a unique opportunity to make nontreaty gillnet fishermen more involved in the decision-making process for long-term preservation and enhancement of the fishery resource without which they will cease to exist. Whether this will happen depends in part on the outcome of the NMFS proposal to eliminate gillnetting on the mainstem of the Columbia. Some observers, in recognition of the role gillnet fishermen have played as allies and advocates for Columbia River salmon, regard the NMFS proposal as anti-fish as well as anti-fishing. Since this also seems at odds with another NMFS provision - establishing terminal fisheries - it will be important for NMFS to clarify this apparent dioscrepancy. At this point, the salmon can use all the friends they can get, and removing the longest and loudest voice in support of the fish could have negative repercussions unintended by the Snake River Recovery Team's proposal. Perhaps another possibility exists, that terminal fisheries such as those in Youngs, Grays and Cathlamet bays, being outside the standard migration pattern of weakened upriver stocks, would be defined as outside the "mainstem." Gillnetting, which has already been shown to be a good match with the terminal lishery concept by the pilot project in Youngs Bay, could then continue as an accepted harvest method within these reserves, with permits limited to numbers which could be accommodated by the terminal fisheries. This regime could conceivably continue until such time as salmon recovery would allow fishing on the mainstem again. Such a system would preserve the core of existing harvest infrastructure and maintain a way of life for families that have been part of a traditional community for generations on the Columbia River. It also would provide those who choose to stay and adapt to the new fishery a chance to work on developing alternative, live-harvest technologies consistent and compatible with being deployed from the small boats owned by the traditional small family businesses that have been the mainstay of the Columbia River fishery for well over a hundred years. But the greatest boon of all, both to fish and fishermen, would be to make fishermen, not just harvesters, but full partners in making "decisions in the long-run best interest of the fishery." 


\section{References for History and Overview section}

1 Martin, Irene. Legacy and Testament: The Story of the Columbia River Gillnetters, Washington State University Press (Pullman, 1994), p. 112

2 Craig and Hacker, Joseph A. and Robert L. "The History and Development of the Fisheries of the Columbia River", U.S. Bureau of Fisheries, Volume XVIV, Bulletin No. 32, U.S. Govermment Printing Office (Washington, 1940).

3 Martin, Irene, et al. "Work Is Our Joy; The Story of the Columbia River Gillnetter," a Lawrence Johnson Production, Oregon State University (Corvallis, 1989).

4 Smith, Courtland. "Fish or Cut Bait", Oregon State University, (Corvallis, n.d.) "Oregon Fish Fights", Oregon State University (Corvallis, 1974). . Salmon Fishers of the Columbia, Oregon State University (Corvallis, 1979).

5 Carlson, Roy L. "History of Research in Archaeology" in Vol. 7, Northwest Coast, of the Handbook of North American Indians, Wayne Suttle, ed., Smithsonian Institution (Washington, 1990), pp. 107-115.

6 Craig and Hacker: p. 142.

7 Boyd, Robert T. "Demographic History, 1774-1874," in Suttle, ed., Northwest Coast, of the Handbook of North American Indians, pp. 135-148. The degree of mortality due to introduced diseases during the period is appalling. For example, mortality solely due to the "fever and ague" of the 1830s on the lower Columbia is believed to have been about $92 \%$, and in the Kiksht-speaking villages of the Portland Basin closer to $98 \%$.

8 Martin, Legacy and Testament: pp. 45-50.

9 Matt Korpela, from a letter to his relatives in Finland in 1896; translated by his grandson Eldon Korpela, a thirdgeneration gillnetter on the Columbia River.

10 Interview with Bill Puustinen by Jim Bergeron and Larry Johnson, December 1988, oral history archives, Columbia River Maritime Museum, Astoria.

11 Norman, Guy, et al. Status Report: Columbia River Fisheries, 1938-93, Washington Department of Fish \& Wildlife, Oregon Department of Fish \& Wildlife (Olympia, 1994), pp. 94-97.

12 Norman, et al. Status Report, WDF\&W, ODF\&W.

13 Craig and Hacker: summary, p. 211. (Emphasis added.)

14 Martin: p. 119.

15 Norman, et al, Status Report: p. 44.

16 Craig and Hacker: p. 188.

17 Martin: p.17.

18 Craig and Ilacker: p.169.

19 Craig and Hacker: p. 170.

20 Craig and Hacker: pp. 183-186.

21 Martin: p. 70.

22 Willingham, William F. Water Power in the Wilderness: The History of Bonneville Lock and Dam, Corps of Engineers (Portland, 1987), p. 47. Willingham contends that at the time of the "308 Plan" in 1931, threats to anadromous fish runs were recognized. Further, he states that North Pacific Division Engineer, Colonel Lukesh raised the issue of fish passage with the Chief of Engineers in 1929. Willingham does not, however, elucidate the response.

23 Netboy, Anthony. The Columbia River Salmon and Steelhead Trout, U. of Wash. Press (Seattle, 1980), p. 75. The quotation, which was widespread in the fishing community at the time, is attributcd to Francis Seufort.

24 Holmes, Harlan B. "The Passage of Fish at Bonneville Dam," in Fish Commission of the State of Oregon, Contributions: 1938-1943 (Portland, 1944), p. 182. In writing of the challenges of designing successful fishways at Bonneville Dam, Holmes, who was one of the team assigned the problem states: "When funds for the construction of Bonneville Dam became available in September, 1933, plans for the structure were represented by little morc than pictorial sketches... Practically the same situation prevailed with respect to the matter of fish protection. In the preliminary report referred to above, there was merely enough to indicate the presence of fishways."

25 Bevan, Donald, et al. Snake River Salmon Recovery Team: Final Recommendations to the National Marine Eisheries Service, NMFS (May, 1994), p. IX-15.

26 Bevan, et al: p. IX-18.

27 Martin: p. 126

28 Craig and Hacker: p. 133.

29 Vissey, Rodney, Regional Director, et al. Draft Environmental Impact Statement. Columbia Basin Project, prepared by the Columbia Basin Project, Bureau of Reclamation (Ephrata, 1975), p. 11-21. 
30 Chapman, Wilbert McLeod. "Fish Problems Connected with Grand Coulee Dam," in Department of Research, Fish Commission of the State of Oregon, Contributions: 1938-1943, (Portland, 1944).

31 Radtke and Davis, Hans and Shannon. "Some Estimates of the Asset Value of the Columbia River Gillnet Fishery Based on Present Value Calculations and Gillnetters' Perceptions," August 1994, p. E-4.

32 Duncan, Angus, et al. Columbia River Basin Fish and Wildlife Program, Northwest Power Planning Council (Portland, December 1994). p. 1-3.

33 Smith, Courtland. "Conservation and Allocation Decisions in Fishery Management," in McNeil, William J., ed. salmon Production. Management and Allocation, Oregon State University Press (Corvallis, 1988) p. 132.

"Garrett Hardin popularized this phrase in an article The Tragedy of the Commons,' Science 162 (December 13, 1968): 1243-1248. Economists refer to the same problem as 'open-access,' and H. Scott Gordon's article 'The Economic Theory of a Common Property Resource: The Fishery,' Journal of Political Economy 62 (1954). pp. 124142 , is a classic statement of the open-access problem."

34 Courtland Smith, in McNeil: p. 134: "A discussion of this point is in E. A. Keen, 'Common Property in Fisheries: Is Sole Ownership an Option,' Marine Policy 7 (1983), pp. 197-212

35 McNeil: p. 134.

36 McNeil: p. 135.

37 Martin: pp. 112-1 13. She further cites as references the following:

Evelyn Pinkerton, ed., Co-operative Management of L ocal fisheries: New Directions for Improved Management and

Community Development (Vancouver: University of British Columbia Press, 1988).

Pamela Madson and William Koss, Washington Salmon:Understanding_Allocation (Olympia, Wash.: House of Representatives, Office of Program Research, 1988), p.23.

Norman Dale, "Getting to Co-Management" In Pinkerton, Co-operative Management, 66. 


\section{INDUSTRY OVERVIEW}

\section{Generic Supplv_and Demand}

Consumer interest in salmon is the fastest growing among seafood products. Each year greater numbers of salmon dinners are being served in restaurants, and sold over the seafood counter.

Most of this growth is coming from the farm-raised salmon industry. Salmon distributors, stung by recent drops in naturally-harvested salmon, and by uncertain seasons for such fish, have increasingly promoted farm-raised fish to their customers. This has left processors of naturallyharvested salmon with everchanging markets. With each new salmon season has come the need to resurrect markets which have been lost. Specialty, niche marketing has become the norm.

\section{Consumer interest in salmon is the fastest growing among seafood products.}

There remains a place for the fish caught naturally from clean waters, nourished by nature's own diet. However, more than ever, demonstrable variables such as quality of product (handling and speed of delivery) and distinctive taste features (color and fat contents) will drive the market.

\section{Trends}

Japan continues to be the world's largest investor in both salmon purchase and salmon production. Some would argue that Japan has positioned itself to control the world market movement of salmon and, therefore, the price as well.

Farm-raised fish have increasingly set new standards for availability and quality of salmon. Availability is year round and not contingent on season setting, weather conditions, endangered species concerns, gear group or fishing group conflicts, or acts of nature such as floods, el Ninos and volcanoes. Buyers can order in the amounts they desire and expect shipment. With little exception, when they and their customers need fish, they'll have fish.

Quality is maintained through rearing and harvest practices using controlled living environments and limited handling which diminish stress to the fish itself. Control of feed can impart flesh conditions such as texture and color that are desireable to both the restaurant owner and consumer. Careful handling diminishes or completely eliminates under skin bruising which creates a loss to distributor or ultimate user. While the product, by some standards, is not exceptional as a culinary treat, it does come ready to use and with no surprises.

\section{Price}

Because about $40 \%$ of the total volume of the world's salmon is now aquaculture raised, they, to a large extent, dictate the world pricing of salmon. Most successfully raised have been Atlantic salmon. The majority are raised in countries which subsidize salmon rearing, or in which labor costs are very low. This allows the fish to go on world markets at a price that, generally, undercuts naturally harvested salmon. In addition, the aquaculture practice of placing huge numbers of salmon on the world market over a short period of time - referred to as "dumping" by some - drives down the price of both farm-raised and naturally caught fish. When this happens just before a naturally caught salmon season, it places that product, which must be harvested immediately or lost, in economic jeopardy as salmon prices world wide plummet.

Local distributors and marketers have virtually no ability to control the distributed price of their naturally caught salmon. As a result they tend to offer fishers conservative prices in an attempt to reduce their risk. 


\section{Markets for naturally caught salmon}

Only those naturally caught products that have been successfully niche marketed have maintained their price. The Copper River King is one that comes to mind. It is prized by restaurants and seafood markets because it is 1) a spring chinook with all the qualities associated with the superior color and flavor of spring chinook; and 2) it has been cleverly promoted to increase and maintain its value in the specialty marketplace.

$$
\begin{gathered}
\text { Now, and even more so in the future, quality will be the } \\
\text { determining factor in value of a salmon. }
\end{gathered}
$$

Now, and even more so in the future, quality will be the determining factor in value of a salmon. There will be room for higher priced fish when they are specially handled and have distinctive color, taste and texture qualities. Without this, any fish will be compared with the uniform, if nondistinctive, farm-raised salmon and probably not be price competitive. 


\section{Economic Profile}

\section{Columbia River non-tribal commercial fisheries selected information from Economic Studies produced by Dr. Hans Radtke 1992 and 1994}

\section{Asset Value}

\$1 10-\$129 million Asset value of the fleet (fishing family vessels, gear, trailers, sheds, docks, etc.) estimated 1994 - does not include buyer or processor investment

\section{Averages from 1938-93}

\$23 million

1,150 jobs

2,000 jobs

7,668,000 Ibs.
Annual average total personal income generated (1938- 1993) in 1993 dollars and prices

Annual average FfE jobs (based on $\$ 20,000 /$ job)

Estimated average number of people employed (This number not included in Radtke report, but gathered by Eaton from other reports and data)

Annual average pounds landed (1938-93, all species)

\section{$\underline{\text { Recent Highs }}$}

\$32 million Recent high in 1988 ( in 1988 dollars, all species)

9,987,000 lbs. Recent high in 1988 (all species)

1,600 jobs Recent high in 1988 based \$20,000/FTE job

\section{References for Economic Profile Page}

"'Some Estimates of the Asset Value of the Columbia River Gillnet Fishery Based on Present Value Calculations and Gillnetter's Perceptions", - Dr. Hans Radtke, August 1994

"Economic Contributions of the Commercial and Recreational Salmon Fishery on the Low er Columbia River (O regon Jurisdiction) A Short Review" - Dr. Hans Radtke, October 1992 


\section{Section 3}

\section{The Product}

- Unique Features of the Fishery and Product - Product Protection 


\section{UNIQUE FEATURES OF THE COLUMBIA RIVER FISHERY AND ITS PRODUCT}

Gillnetting on the Columbia River is a unique industry. In a time of highly sensitive environmental issues, this harvest method is extremely easy to monitor and can target specific varieties of fish. It is a major contributor to small, local economies and indeed to the culture of communities on the lower River. It harvests a quality fish at the peak of its life cycle and at the same time provides a livelihood to families that depend on this resource for stability and work near their homes.

\section{Regulation}

According to Ron Roler, gillnetting on the lower Columbia is so closely monitored it is almost "over regulated."( 1) No fewer than seven federal, state and tribal agencies or interests hold some control over the River's salmon harvest. The area fished is relatively small and easily enforced when compared to other fisheries. Some fisheries managers have said they wish all fisheries were as easy to manage as that found in the lower Columbia River. This allows the fishery to be extremely responsive to changes brought on by variances in predicted run size or timing.

\section{Gillnetting on the lower Columbia is so closely monitored it is almost "over regulated."}

\section{Environment}

Lower Columbia gillnetting is considered a clean and environmentally friendly industry. It uses very little fuel compared to the ocean fisheries. Small-scale fishermen catch ten to twenty tons of fish per ton of fuel consumed while the large-scale fisheries catch only two to five tons of fish per ton of fuel.(2) This is an established fishery with docks for off-loading, shipping and processing already in place. It leaves no residue that marks the River afterward, nor does it harm any other industry along the River.

\section{It leaves no residue that marks the River afterward, nor does it harm any other industry along the River.}

There has been no known capture of non-fish endangered species, and adjusting the size of the gillnet mesh allows fishermen to target specific species of fish. And unlike some large-scale fishing fleets that reportedly destroy millions of tons of bycatch each year, small-scale fishermen, like the Columbia River gillnetter, waste virtually none.(3) The natural cycles of the fish allow the gillnetter to fish for certain runs of fish simply by fishing on specific days, times, and places.

\section{Product}

The salmon product is considered superior by those with expertise. J. R. Rabago of the Admiral Way Thriftway store in Seattle says the texture of pen-raised fish (versus wild salmon) is too soft. He has run taste tests with his fish counter customers and they prefer the wild fish for flavor and texture.(4) Terry Gaul, another seller of fish in Seattle, has had his customers ask him "What's wrong with this fish?" in reference to farmed salmon when they had previously purchased wild salmon.(5) According to Wayne Ludvigsen of Ray's Boathouse restaurant in Seattle, who buys wild fish exclusively, wild salmon are "luxurious". (6) He feels that farmed fish are too high in fat and consequently cook up differently than a pen/ocean raised fish.

Diet is a big factor in fish but so is their life-style. Fish that spend their lives swimming in circles in a small pen are much higher in fat content than fish that compete for their food source and swim thousands of miles in varying habitats during their natural life cycle. Farmed fish do indeed have a higher fat content; a wild salmon has $4.3 \%$ fat content versus $9 \%$ fat content of a farmed Atlantic salmon.(7) And this higher fat content has brought into question whether a farmed salmon has the same beneficial "omega 3' $\mathrm{s}$ "-a beneficial fatty acid in fish oil reported to combat cholesterol -as a wild salmon.(8) 


\section{Fish that compete for a wild, varied diet of their natural foods are a sleek, efficient source of protein and beneficial oils.}

Fish that compete for a wild, varied diet of their natural foods are a sleek, efficient source of protein and beneficial oils. As people become more concerned about additives and pollution factors in the food they eat, these fish will be more in demand. For instance, the Japanese are noted for their preference for seafood and more and more of them (nearly 10\% of the current population) buy their food in a co-op format, preferring to buy organic.(9)

\section{Culture}

While organic origins of wild fish are certainly one of the industry's unique and appealing qualities, perhaps even more unusual is the culture surrounding the fishery. As a society, we are constantly reminded of the need to return to family values and the hard-work ethic upon which our country was founded. Fishing communities stand out as an exception to the rule of the flight to the large population areas. The boats are owned, maintained, and operated by family members, often giving the younger members of the family the chance to earn money without leaving the community, and while learning the trade from experienced fishermen. There is a rich heritage in these fishing towns and a very real sense of community that grows out of interdependence.

\section{There is a rich heritage in these fishing towns and a very real sense of community that grows out of interdependence.}

The local economies are supported by the river fishery. Where five to thirty people are supported by a million dollar investment in a large-scale fishing vessel, 500 to 4,000 people may be employed for the same investment in a small-boat fleet.( 10)

A healthy fishery allows people to stay on homesteads that have been in families for generations and provides economic independence. Unlike fish farm operations, often bankrolled by large corporations (1 1), gillnetters on the lower Columbia are all small business people; an independent group, ethnically diverse, and stubbornly self-sufficient. They are not unlike the fish they catch. They return to the River in season and move on the currents and tides in nature's choreographed dance for life and survival.

\begin{tabular}{c}
\hline A healthy fishery allows people to stay on homesteads that \\
have been in families for generations and provides economic \\
independence.
\end{tabular}

\section{References for Unique Features section}

1. Telephone interview with Ron Roler of Battle Ground Regional Office, Washington State Department of Fish and Wildlife, March 9, 1995

2. Solvieg Torvik, "FISH Going, Going, Go...," Sunday Seattle Post-Intelligencer, Section I, December 11, 1994

3. Torvik, "FISH..."

4. Telephone interview with J.R. Rabago, Admiral Way Thriftway Store, Seattle, WA. May 3, 1995

5. Telephone interview with Terry Gaul of Larry's Markets, Queen Anne Hill, Seattle, WA. May 3, 1995

6. Telephone interview with Wayne Ludvigsen of Ray's Boathouse Restaurant, Seattle, WA. March 14, 1995

7. Mike Wyatt, "A Guide to Seafood Down on the Farm," Simply Seafood, Volume 5, Number 1, Winter, '95

8. Daniel Shaw, "Just For the Health of It!", Simply Seafood, Volume 3, Number 2, Spring '95

9. Peter Redmayne, "Japan, Selling Seafood Is Not So Simple," Seafood Leader, Volume 14, Number 14, July/August, '94

10.Torvik, "FISH..."

1.Sylvia Nogaki, "Fishing For Profits," Sunday Seattle Times, Section C, September 28, 1986 


\section{PROTECTION OF PRODUCT}

In order for the expanded terminal fisheries concept to be economically and politically successful, it will be important to establish guidelines for allocation and protection that will meet the needs of many. This would include needs of the agencies, the tribes, ocean sport and commercial fisheries, sport and commercial fisheries in the mainstem Columbia, and sport and commercial fisheries in the terminal fishery areas themselves.

The concept is that some fish returning to terminal areas will be taken in non-terminal fisheries, and the remaining fish, perhaps the majority, will be taken in terminal sites as fish return to the net pens in which they were raised. Project success will hinge on 1) controlling the number of returning fish taken in interception fisheries, and 2) the financial assistance those intercepting fisheries contribute to the cost of raising the fish. This section explores allocation and interception.

Project success will hinge on I) controlling the number of
returning fish taken in interception fisheries, and 2) the
financial assistance those intercepting fisheries contribute to
the cost of raising the fish.

\section{Interception and terminal fisheries allocation}

Spring Chinook. Lower River

This species, more than any other, provides the best potential to drive the economic machinery necessary for the fishery to prosper. Spring chinook are a highly prized fish of excellent quality bringing high value to the marketplace. Harvest must, therefore, be closely regulated to gain maximum economic benefit for the program which will raise them.

\section{Spring chinook are a highly prized fish of excellent quality bringing high value to the marketplace.}

These spring chinook will be released in early spring, will mature primarily in Alaska waters, and return in the March to early June time frame.

Ocean fisheries - Generally spring chinook are taken in ocean fisheries as three year and four year old pre-adults in the northern commercial fishery off Washington, British Columbia and Alaska. Recent ocean interception levels of about $16 \%$ should be acceptable for purposes of protecting the terminal catch.

In-river fisheries - Once back to the river, there may be some taken in the mainstem if a sport or commercial fishery is granted there. The numbers would be small. Weather factors and river conditions, the size of the returning run, and protection of ESA listed Snake River spring chinook will determine the extent of mainstem opportunity for both sport and commercial fisheries.

Terminal areas - It appears that the majority will be available to fisheries only in the terminal areas, where the quality is expected to be good to excellent.

Allocation - The goal is to have orderly commercial and recreational fisheries and reduce gear interaction and conflicts as much as possible. This benefits both fishing groups. Since ocean and in-river impacts are expected to be small, no action is suggested here. For terminal fishery areas, recommendations are found in the section on OPERATIONS. No quotas would be established for either sport or commercial fisheries, allowing, instead, fishing time to drive catches.

\section{Earlv Coho}

This species provides the best potential for large numbers of fish to harvest. They will be released in April, will mature primarily in Oregon ocean waters, and return in the late-August to midOctober time frame.

Ocean fisheries - At most, $40 \%$ could be taken as adults in the commercial troll and sport fishery off the coast of Oregon and Washington. Directed ocean harvest will be driven by protection of Oregon Coastal Natural (OCN) coho which is being considered for ESA listing. 
In-river fisheries - Once back to the river, many could be taken at the Buoy 10 sport fishery. The percentage is estimated at between $10 \%$ and $20 \%$. Weather factors and river conditions, the size of the returning run, and protection of ESA listed Snake river fall chinook will determine the extent of mainstem opportunity for both sport and commercial fisheries.

Terminal areas - It appears that greater than $50 \%$ of the adult run will be available to fisheries in the terminal areas. Quality is expected to be good to excellent, but will deteriorate the longer fish are in fresh water.

Allocation - The goal is to have orderly fisheries and reduce as much as possible gear interaction and conflicts. This benefits both fishing groups. Since ocean and in-river impacts are expected to be large, an allocation quota should be established and cnforced for ocean fisheries. For terminal fishery areas, recommendations are found in the section on OPERATIONS. Within terminal areas, no quotas would be established for either sport or commercial fisheries, allowing, instead, fishing time to drive catches.

\section{Late Coho}

It is not anticipated that late coho will be utilized in an expanded net pen project. If that changes, the guidelines recommended above for early coho should suffice.

\section{Fall Chinook (Rogue River Stock)}

This species provides chinook for markets following completion of Alaska and Canada fisheries. The market can be volatile, dramatically changing from year to year.

The fall chinook will be released in late July, will mature primarily in southern Oregon ocean waters, and return in the August to late-September time frame.

\section{This species provides chinook for markets following completion of Alaska and Canada fisheries.}

Ocean fisheries - Most will be taken as pre-adults, about $45 \%$, in the troll fishery off Oregon. Chinook directed recreational and commercial fisheries will have seasons for adults driven by protection of northern California chinook stocks and Oregon chinook OCN coho stocks. In-river fisheries - Once back to the river, there may be some taken in the mainstem if a sport or commercial fishery is granted there. The numbers would be small. Weather factors and river conditions, the size of the returning run, and protection of ESA listed Snake River fall chinook will determine the extent of mainstem opportunity for both sport and commercial fisheries. Quality is expected to be good to excellent with red flesh coloration, a desireable trait.

Terminal areas - It appears that the majority, perhaps $75 \%$, will be available to fisheries in the terminal areas, where the quality is expected to be good to excellent.

Allocation - The goal is to have orderly fisheries and reduce as much as possible gear interaction and conflicts. This benefits both fishing groups. Ocean and in-river impacts should be carefully watched and calculated, although no harvest restraint action is suggested here. For terminal fishery areas, recommendations are found in the section on OPERATIONS. Within terminal areas, no quotas would be established for either sport or commercial fisheries, allowing, instead, fishing time to drive catches.

\section{Tribal/non-tribal allocation}

For the most part, the court casc US v Oregon establishes guidelines for harvest sharing that will determine, along with ESA concerns, what happens on mainstem tribal/non-tribal take of upriver bound fish. It should be made clear that lower river commercial fishing interests are not abandoning their claim to fish the Columbia mainstem when biologically justifiable fisheries are possible.

However, it seems mainstem harvest opportunities in the near future will be unpredictable at best. For both tribal and non-tribal fishermen to survive this crisis will take cooperation between the two in terms of production, harvest sharing, and joint utilization of available federal and state funds for their mutual projects. 


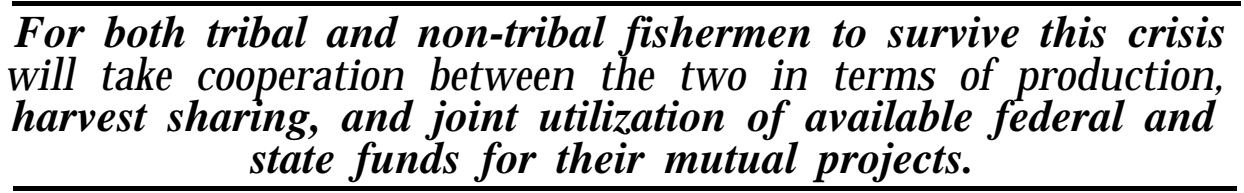

For lower river commercial fishermen, successful lower river terminal fisheries will provide increased fishing opportunity, and temporarily decrease reliance on mainstem fisheries. As tribal production becomes increasingly successful, tribal interests will want to assure access to their production. An agreement between tribal and lower river non-tribal fishermen might establish: projects;

1) guidelines for sharing of Mitchell Act or other federal funds for respective production

2) a sliding scale, or range, of lower river mainstem impacts on upper river bound stocks based on a) estimates of lower river and upper river bound harvestable stocks (non-tribal production), and b) estimates of upper river bound tribal production. For instance, the greater the numbers, the greater the lower river impacts (see Willamette plan for modeling concepts).

Rather than establish what this agreement should be, the effort of this report is simply to note that such an agreement would be instrumental in all meeting their goals. It is encouraged that such an agreement be actively pursued by the states. 


\section{Section 4}

\section{Operations}

- Location and Geographic Issues

- Quality Control Standards

- Production/Harvest Control

- Performance Audits 


\section{LOCATION AND GEOGRAPHIC ISSUES}

In its 1993 Strategy for Salmon, the Northwest Power Planning Council recommended that terminal fishing sites be identified and developed to harvest abundant fish stocks while minimizing the incidental harvest of weak stocks. The Council called on BPA to:

"Fund a study to evaluate potential terminal fishery sites and opportunities. This Study should include: general requirements for developing those sites (e.g. construction of acclimation/release facilities for hatchery smolts so that adult salmon would return to the area for harvest); the potential number of harvesters that might be accommodated; type of gear to be used; and other relevant information needed to determine the feasibility and magnitude of the program."

\section{The Columbia River is the ideal environment for a terminal salmon fishery....}

The Columbia River is the ideal environment for a terminal salmon fishery because of the following regional geographic reasons:

a) The river has a varying width, of 4 to 8 miles. The flow of fresh water will flush selected sites daily. Natural food organisms needed for the fish are provided. The many islands, sand bars and sloughs create protected rearing sites for the project.

b) Many natural runs on the lower river are extirpated. Therefore, conflicts with lower river natural runs can be minimized.

c) The lower river's width and varying depths offer large areas that could accommodate considerable numbers of rearing pens. Adequate water flow and velocity characteristics will prevent degradation of water quality. Migrating smolts and adults will avoid dams, the main obstacle for salmon survival. Opportunities for predators will be reduced due to a brief journey to and from the ocean.

d) The enforcement of fishing regulations will be simplified. Time spent attempting to observe and provide surveillance for the entire lower river will diminish. Funding for enforcement could be more efficiently utilized as fewer enforcement officers could monitor larger numbers of fishermen contained in smaller boundary fisheries.

e) Returning salmon will be harvested at peak quality. The adults will be mature at the time of returning to the site. Young, immature fish will not be impacted by this terminal fishery. Consumer demands for Columbia River salmon may once again be filled.

f) The terminal salmon project would supplement the economy through enhanced sport and commercial fisheries. Lower river commercial and sport fisheries have been drastically reduced due to weak, or ESA listed, upriver stocks. The commercial fishing infrastructure of canneries, experienced fishermen with gear/boats, and supporting businesses are in place. The traditional harvest of salmon has been the center for economic vitality and heritage for lower river communities. A great deficit has been experienced due to the loss of this key element.

\section{SITE SELECTION}

The BPA funded study mentioned above was begun with staff from both ODF\&W and WDF\&W assigned responsibilities. Here is a summary of their work related to site assessment and selection.

A) Criteria used for site selection include:

1. Large area and water depth: the pens are large and need depth at low tide.

2. Flow and velocity: to prevent degradation of water as organic matter and nutrients are introduced during rearing.

3. Shelter from extreme weather conditions: protection from high winds during winter storms, usually from the south to southwest, waves and debris. 

fishermen.

4. Site access: local fleet that could operate at the worst of times and attract nonlocal cause imprinting.

5. Water's chemical properties to attract returning adults: unique water source that would

6 . Chance of interaction of commercial fishermen and other river users: commercial traffic (tugs, ferries and log raft) or recreational traffic should be avoided.

7. Accessible to and can accommodate fishing vessels and fish buyers: moorage facilities, fuel, boat ramps, parking, hoist, on land sites or floating facilities must be possible.

8. Definable boundaries: for enforcement and biological monitoring, recognizable markers associated with permanent landmarks are preferred.

9. Low impact on ESA stocks and other non-targeted species

B) Using historic data from previous test and commercial fisheries, and meetings with Salmon for All fishermen, a working list was established. Twenty-five sites were evaluated for terminal fisheries potential, listed by state and river mile:

\begin{tabular}{lc} 
Washington & RM \\
\hline Grays Bay & 22 \\
Steamboat Slough & 34 \\
Elochoman River & 36 \\
CathlametChannel & 40 \\
Coal Creek Slough & 56 \\
Fisher Island Slough & 60 \\
Cowlitz River & 68 \\
Carroll's Channel & 70 \\
Martin Slough & 80 \\
Lewis River & 87 \\
Lake River & 89 \\
Camas Slough & 120
\end{tabular}

\begin{tabular}{lc} 
Oregon & RM \\
\hline Baker Bay & 5 \\
Skipanon Waterway & 11 \\
Youngs Bay Expansion & 12 \\
Tongue Point Basin & 18 \\
Svensen Island & 23 \\
Big Creek & 27 \\
Blind Slough & 28 \\
Clifton Channel & 36 \\
Coffee Pot Island & 43 \\
Westport Slough & 44 \\
Wallace Island & 49 \\
Bradbury Slough & 55 \\
WahkeenaPond & 135
\end{tabular}

Ranking of potential sites is based on rearing and harvest potential, as well as previous terminal and test fishery data. Table 1 lists the results of the site review, including a ranking of high, medium or low priority to indicate locations that should be given present and future consideration.

a) Nine sites were considered to have high priority, for immediate consideration:

Washington

Grays Bay

Steamboat Slough

CathlametChannel
Oregon

Tongue Point Basin

Big Creek

Blind Slough

Svensen Island

Clifton Channel

Wallace Slough

b) Six sites had medium rankings, but with four of these having one or more criteria ranked 0 (failure), leaving two sites for possible future consideration.
Lewis River
Bradbury Slough

c) The remaining sites had low priorities and would not be given further consideration.

Fisher Island Slough

Cowlitz River

Baker Bay

Carroll's Channel

Martin Slough

Lake River

Coffee Pot island 
d) Established production sites at Youngs Bay and Wahkeena Pond were not ranked.

\section{Final Site Selection}

1. DoesPoint Basin $(\mathrm{OR})$ - largest potential rearing \& harvest area with greatest depth of all sites. Could house as many pens as Youngs Bay. It has good flow and velocity characteristics to prevent degradation of water, sheltered from winter storms, excellent access from Highway 30 and there are large piers in place.

Good chemical properties of the water will allow imprinting due to the flow of several creeks including the John Day River. Proximity of Astoria offers fuel, moorage, on-water fish buyers and boat ramps, etc. The basin is close to the major concentration of fishermen in Astoria and Ilwaco.

Straying of upriver hatchery stocks heading to Oregon tributaries must be monitored. Additional test fishing will be done during spring and fall harvest windows.

Interactions between commercial fishers and other river users will occur in the basin. The John Day boat ramp is popular with sport fishermen. Sports fishermen also fish for sturgeon in the basin. Other basin users include the Job Corps Center, a US Army Corps of Engineers dock, and the new MERTS facility. Boundaries are easily defined.

2. Deep River/Gravs Bav (WA) - could accommodate a modest number of fish pens. There is currently one net pen rearing facility in Deep River upstream of the Highway 4 bridge. The lower stretches of Deep River are ideal for rearing. Excellent flow and velocity requirements by flushing tides and freshwater inflow from three sources (Deep River, Grays River \& Seal Slough).

Grazing operations could impact this site with nitrogen and phosphate pollution. Warm temperatures could be a factor in late summer. Rearing practices could avoid the warmer times. Good protection from storms. Roadways do allow access to water though permission from private landowner would be required.

Flow and chemical distinction are present to attract returning adults back to the area. While there are some shallow areas, the area needed for harvest could support a modest number of gillnet boats. Washington State law denies commercial net fishing for salmon in Grays Bay, Grays River, and Deep River from December 1- August 31 . These laws would have to be modified before terminal fisheries could be conducted. Mooring is available in several marinas.

Interaction between sport and commercial fishermen can be expected during spring, summer and fall. Boundaries are easily defined. WDF\&W hatchery exists on the West Fork of Grays River. Minimizing impacts to nontarget stocks/species would require fall fishing prior to the arrival of chum and winter steelhead, or spring fishing after winter steelhead had moved out of the bay.

3. Blind Slough (OR) - meets minimum depth criteria of eleven feet where pens would be placed. Depending on flow and velocity limitations, and based on available area, the number of pens could approach that estimated for Tongue Point. Flow and velocity are dictated by runoff from Gnat Creek and tidal action. Freshets and rainfall will be factors.

Good protection from storms and debris and county roads access the site. It will need additional piling, floats and dock. Excellent potential for growth. High probability of attracting returning adults since Gnat Creek is the sole tributary draining into the Slough. It is a narrow, confined channel and will allow a limited number of boats. This site might not attract nonlocal fishermen. Lack of strong currents can accommodate modified or stationary gear at any stage of tide. 
Moorage is available at nearby floathouses. There is a private boat ramp near the lower Blind Slough/Barendse Road Bridge. Expect minimal limited interaction with wildlife watchers. Boundaries are definable. Good potential to maximize harvest on target stocks because of the confined harvest area. Low chance of nonlocal fish straying due to flow velocity characteristics and unique water quality.

4. Steamboat Slouch (WA) - is constrained but meets the area and depth requirements. It will accommodate a modest number of pens. A buying station could accommodate pens and piling at the upriver end of Steamboat Slough. The flow, velocity and tidal action are adequate. It will offer protection from winter storms. Access to the rearing pens might be restricted during high flows or flood events.

There Is good road access. Sufficient flow can attract returning adults, but may lack distinctive chemical characteristics for precise homing. This site may not attract nonlocal fishermen. Washington State law prohibits commercial net fishing for salmon in Elochoman River, sloughs, and Skamokawa Sloughs from December 1 through August 31, a condition that will need to be changed before terminal fisheries are conducted.

Accessibility is not a problem. There is a fishing dock and boat basin. These are commercial fishing communities, so expect limited interactions between commercial fishermen and other river users. There will be some sport fishing for sturgeon, steelhead and cutthroat during restricted periods of time. Establishing boundaries would not be a problem but set markers will need to be placed. Skamokawa Creek supports runs of fall chinook and coho salmon and winter steelhead.

Maximizing the catch of target species, while not impacting the non-target species and stocks, would require timing fall fisheries after the peak passage of ESA stocks and prior to the peak arrival of winter steelhead trout. Spring fisheries would need to be timed after the peak passage of ESA stocks and prior to the peak arrival of summer steelhead.

5. Clifton Channel (OR1 - has the area and depth to meet the minimum criteria. Pilings are available to secure pens and there is a buying station, Adequate flow and velocity characteristics are present. The site is shielded from storms and resulting debris. Northwesterly winds could create moderate wind chop. Land access is good.

Hunt Creek above the rearing site should provide good imprinting water. This channel is an established fishing area and is fishable during all stages of the tide. A fish buying station will offer road access, a hoist, and moorage. Water based buyers are in close proximity. River traffic is limited to tugs towing log rafts and sports fishermen during spring months if a mainstem spring chinook season is open. Boundaries would be easy to establish using navigationai markers.

The potential of Clifton channel to maximize the harvest of target fish stocks while minimizing the impact on nontarget and sensitive fish stocks will be carefully assessed by test fishing. A harvest window must be established. The channel is open ended and is a migration route for some upriver stocks of fish.

6- Cathlamet Channel (WA1 - This channel exceeds the minimum area and depth requirement to accommodate a maximum number of rearing pens. The Port of Cathlamet is located here and has docks and pilings. This includes the upstream

entry into Elochoman Slough as a potential pen rearing location. The Columbia River flow should prove adequate to maintain water quality. Activities associated with the Port of Cathlamet are a potential source of nitrogen, phosphate, and turbidity that could impact this site. The flow and chemical distinction are present to attract returning adults. 
The channel offers limited protection from most extreme weather conditions. Possible flood conditions would limit access to net pens. Road access is fair. The large area would attract nonlocal fishermen. Needed amenities are close at hand. Fish buyers are nearby in small river communities.

Cathlamet Channel area appears to be relatively free of controversial social and political issues. It is outside the shipping lane but does get log raft, barge, and pleasure craft traffic. Puget Island and the Nassa Point area are popular spring chinook and summer steelhead sport fishing sites. Boundaries would need to be marked to delineate open and closed waters.

Impacts to ESA stocks In Cathlamet Channel are undocumented. Maximizing fall salmon harvest while limiting Impacts to nontarget stocks and species require knowledge of ESA stock presence during August through October and late April to May. Test fisheries will be used to gather this information. Fall fisheries would need to be timed after the passage of ESA stocks and prior to the arrival of winter steelhead trout. Spring fisheries would need to be timed after the passage of ESA stocks and prior to the arrival of summer steelhead.

7. Wallace Slough (ORI - The location of a private buying station provides the potential space for securing net pens. Sufficient depth and area for a modest number of pens is available. Adding pilings will offer more production along the downstream bank from the confluence of the Clatskanie River.

Tidal effect at the potential rearing site is minor at the flood stage and flushing action maximized during the ebb tidal stage.

It is well protected from winter storms. Heavy run off from the Clatskanie River should not affect the rearing site since the net pens will be located upstream of the confluence. There is a very high probability of attracting returning adults.

Paved road is available to the fish buying station. About 20 fishermen currently fish this drift. Additional harvest location along the Oregon shore and upstream of Wallace Island called the Patton Drift is a traditional fishing site with potential. Nearest boat ramp is in Clatskanie and is narrow and lacks depth at low tide.

Moorage at the station is used by the commercial fleet. Potential exists for water based fish buyers and additional temporary moorage. Other desirable features include a hoist, parking, and proximity to roads. Fuel is not available, but is a future possibility.

Interaction between commercial fishermen and others is minimal except for recreational traffic heading to mainstem. Definable boundaries do exist, although on the Patton Drift they are not as defined.

Non-local spring chinook are known to use the Wallace area with their wandering migrational behavior. Fall runs of chinook and coho destined for the Clatskanie River will be present. However, impact of potential fall fishery on non-local fall chinook, coho, and steelhead are anticipated to be low. Test fishing will determine background impact levels for non-local fish stacks.

\section{HOMING AND STRAYING}

Precise homing of adult salmon to terminal rearing and release sites is of greatest importance to assure maximum harvest potential while at the same time minimizing the potential of strays interbreeding with genetically dissimilar populations. Information on homing from smolt releases at traditional hatchery sites that have provided terminal harvest opportunity is available; however homing data from net pen acclimation and release experiments are still being evaluated. 
Monitoring of homing and straying of adults from net pen reared smolts will require annual evaluation and analysis to determine if expected rates are attained and within expectable limits.

For each site with a high ranking, homing and straying expectations will be estimated for potential salmon stocks. To accurately estimate homing and straying rates, however, is a difficult task.

\section{References for Location and Geographic section}

Washington Department of Fish and Wildlife. 1994, Columbia River: Fisheries Research Project Annual Report.

BPA, ODF\&W, WDF\&W, CEDC. 1994. Potential Lower Columbia River Terminal Salmon Fisheries, Executive Summary. 


\section{OUALITY CONTROL STANDARDS}

The fishery this project plans to build needs to adopt product standards that will favorably drive the harvested fish into markets seeking those standards. Success depends on the willingness of fishers and processors to establish voluntary quality standards and to then adhere to them. The biggest incentive would be a demonstrably higher price based on increased quality. But it should be recognized that within the marketplace price will most likely follow implementation of high standards. Some standards would include, but are not limited to:

- Immediate and consistent on-board icing of fish to quickly reach and maintain optimum flesh temperature for storing and handling.

- Bleeding and, perhaps, dressing to be done on-board.

- No throwing or pughing of fish. Transfer to fish holds would be by trough or slide. When hand transfer is necessary, two-hand handling by gills and tail will be used to reduce external and internal bruising. Slides, troughs, or conveyors will be used in transferring fish from vessel to shoreside totes or bins.

- Processors must work to keep on-shore product from direct sunlight, and move it through preparation for distribution in the most expeditious manner possible. Adherence by processing crew to handling and temperature standards will be critical to the quality of the fish. Processors need to be creative in finding ways to handle volumes of fish so that quality is not compromised.

Success depends on the willingness of fishers and processors
to establish voluntary quality standards and to then adhere to
them.

In the spirit of improving quality and maximizing profits, other standards could and should be adopted. An annual evaluation should be done to learn if standards are adequate, should be improved, and if compliance by all is sufficient.

\section{Certification}

A voluntary certification program is recommended, both for fishers and processors. Administered by a group or agency, such as Salmon for All or the Sea Grant program, this program would be open to all who wish to participate. The intent would be that fishers taking a quality control class would receive a quality certification sticker to be placed upon their boat, and their name listed on a schedule available to all in the industry. Similarly, processors and their handling crews would take a certification class with the intent that a certification sticker would be mounted at their plant and buying stations, and their names listed on a schedule available to all in the industry.

This allows fishers to seek processors, and processors to seek fishers, who are mutually committed to quality. In this partnership each can expect to receive maximum economic return and perhaps gain a marketing advantage not available to those less concerned with quality.

\section{This tag would serve as a quality promise to the fish retailer and ultimate consumer.}

It is further recommended that the industry develop a "quality certification" tag that could be placed on each fish shipment, and perhaps even on each fish. This tag would serve as a quality promise to the fish retailer and ultimate consumer. It would be available only to quality certified processors who do business exclusively with quality certified fishers. 


\section{PRODUCTION CONTROL}

All production would continue to be under the jurisdiction of the states, with approval of the National Marine Fisheries Service. Actual production would continue under the program now being called the CEDC Fisheries Project. While its name and administrative link may change in the development of an expanded production project, its staff, expertise, facilities, and working relationship with the fish agencies is valuable and should be maintained.

Regularly scheduled annual meetings would be held. These meetings would include CEDC staff, WDF\&W and ODF\&W staff, NMFS staff, and others as needed. Those at the meeting would be responsible for following all project guidelines in determining:

- which species are to be raised in project facilities

- inventory of appropriate egg and/or fry source and numbers available

- release goals

- survivability goals

- timelines for transfer to net pens

- feed schedules and type of feed

- timelines for releases

The information noted above would be determined in advance, even two or three years prior to implementation year, if possible. The key is to have long range plans that can draw support and encouragement from appropriate agencies, groups, and individuals. To generate plans for the implementation year only, will defeat the very concept of a long range business plan. Any advance determinations so made would be altered as new information became available.

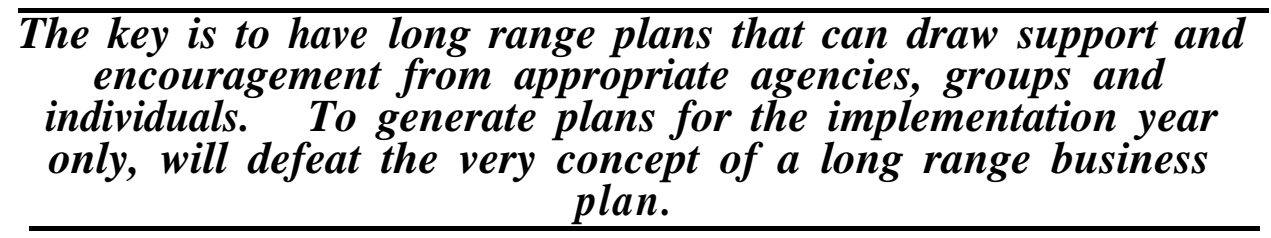

\section{HARVEST CONTROL}

\section{Seasôn Setting}

Setting seasons will be cooperatively conducted between the States of Oregon and Washington. It is possible that decisions will be made by the Columbia River COMPACT. But because some terminal fishing will not be conducted on concurrent waters, it may not be necessary to conduct business under the regulations and guidelines of the COMPACT. In that event, a new effort could be designed based on the following guidelines:

- Agency lead will be taken by the Columbia River management staff of each state. They will make recommendations for the review council. Recommendations will meet all departmental and state regulations, and NMFS guidelines.

- A seven member terminal harvest review council will be made of one representative each of the following groups:

The terminal fisheries project

WDF\&W Commissioner most closely affiliated with lower river

ODF\&W Commissioner most closely affiliated with lower river

One commercial terminal fisher, Washington at-large

One commercial terminal fisher, Oregon at-large

One lower Columbia sport fisher, Washington at-large*

One lower Columbia sport fisher, Oregon at-large*

* for purposes of this council, a person associated with the Columbia

charter boat industry is considered a sport fisher

- Meetings will be held in the lower river region as needed for timely decision making. 
- Meetings will be open to the public. Public testimony will be allowed. Public notification will be posted and mailed consistent with legal requirements.

- Meetings will be chaired by the Commission representative, alternating each year between the states.

- The Council will operate by consensus.

- When consensus cannot be reached, a decision will be reached by:

1 - the two commission representatives.

If they cannot agree,

2 - the two chairs of the Fish and Wildlife Commissions.

If they cannot agree,

3 - the two Fish and Wildlife Commissions meeting in joint session.

\section{Season Guidelines}

There may be considerable interest in these terminal fisheries as they grow in fish numbers and reputation. It is important to establish guidelines that will lead to good initial decision making and set justifiable precedents. Some areas are larger than others, offering room for more boats. Some will raise more fish. Some will be more easily accessed by fishers.

\section{It is important to establish guidelines that will lead to good initial decision making and set justifiable precedents.}

The following guidelines are recommended:

\section{Commercial Fisheries}

- Fisheries shall be orderly.

- Whenever possible and practical, all terminal fishery areas shall open and close for harvest at the same time. This will avoid "gold rush" openings where fishers move from one opening to another, and encourage fishers to fish their nearest terminal area.

- There shall be an annual review to learn if it is necessary to reduce the numbers of vessels in an area. If this becomes necessary, consensus building among the affected fishers will be undertaken immediately following the season in question. This provides a full year to consider options, work out details, and reach fair decisions.

- In cooperation with the industry, gillnets will be the commercial fishing tool of choice in terminal areas. Guidelines for gear mesh size, length and depth could be established for each terminal area, if necessary.

\section{Seasons should be set to maximize economic return from the salmon product.}

- Seasons should be set to maximize economic return from the salmon product. Spring chinook, for example, will be most valuable as a "shipped fresh" product. Since the returning salmon are expected to mill in the terminal area, factors like access to market may be more important than providing a continual opening. For example, the commercial fishery might be set from dawn to dusk on Monday, and from dawn to dusk on Thursday. This would provide a more constant and manageable flow of fresh salmon into NW markets hopefully maintaining maximum prices by balancing supply with demand; eliminate the expense to fishermen of low catch days immediately following openings; provide product to processors in a timely way which will not require expensive overtime or weekend hours. Also, product is more efficiently transferred to regional markets using transportation, both ground and air, that is traditionally weekday oriented. NOTE: The above is an example only. It is possible that some terminal areas will need night time fishing because of clear water, depth of water, and lack of current.

- In the event of a conflict over fishing time, the determining factor shall be timely take by commercial fishers to preserve premium marketability. Salmon in fresh water begin to lose flesh and color qualities that negatively affect value in the marketplace. For instance, with fall chinook, it may be determined they should be taken within four days after moving into the terminal area. 
The distribution of fishing time would then be dictated by the need for commercial fisheries no longer than four days apart.

\section{In the event of a conflict over fishing time, the determining factor shall be timely take by commercial fishers to preserve premium marketability.}

\section{Recreational Fisheries}

- Even though this project is designed for maintaining lower River commercial fishing infrastructure, sportfishing should be allowed in terminal areas. Seasons would be established at the same time commercial seasons were set.

- These seasons should be established at the start, even though interest may initially be low, Doing so will set precedent and eliminate problems later on. For instance, because there may be little effort initially, it may be tempting to allow sportfishing seven days a week in terminal areas. However, it is entirely possible that as terminal area sportfishing interest grows, some kind of change would be needed to avoid commercial/sport gear conflicts. When that change is made, some sportfishers are certain to complain that their fishing time is being curtailed in favor of the commercial fishery. Seasons established now will eliminate unnecessary conflicts in the future.

\section{These seasons should be set to maximize opportunity without unnecessarily conflicting on the water and at dock facilities with the commercial fleet.}

- These seasons should be set to maximize opportunity without unnecessarily conflicting on the water and at dock facilities with the commercial fleet. For example, fashioned around the commercial season suggested above, sportfishing might be allowed from dawn Tuesday to dusk Wednesday, and from dawn Friday to dusk Sunday.

- Maximize the economic potential of sportfishing. The schedule suggested above provides two days of week-day fishing for local residents and/or retired fishers, and three days of weekend fishing. This schedule appears to meet the needs of local residents who don't desire to fight for space with weekenders. It also allows full weekend fishing to accommodate those who travel and may stay in local motels or campgrounds, eat in local restaurants, and take advantage of local recreation like movies, museums and art galleries.

\section{Enforcement Guidelines}

A critical part of any orderly, legal fishery is the ability to enforce the guidelines, rules, regulations, and laws governing that fishery. While the industry is responsible for adhering to the law and can do some of its own policing, the fishery must allow observation by law enforcement personnel.

Existing enforcement codes and practices used for the Columbia River mainstem and developed for use in Youngs Bay have proven effective. Once clear boundary lines are established for each terminal area, based on findings from test fishing and coordinated with either existing or manufactured landmarks, no major changes or challenges are anticipated.

Should problems arise, it is recommended that enforcement personnel work with fisheries project leaders, harvest managers, and industry leaders to design workable solutions. 


\section{PERFORMANCE AUDITS}

As with any endeavor worth pursuing and from which success is anticipated, it will be necessary for this program to have guidelines and standards against which success can be measured. This project willl be under close scrutiny by many agencies and groups. Meeting or exceeding standards will give the project the greatest chance for continued support and survival.

The administrative agency will be charged to develop, approve, implement and evaluate these standards. It is anticipated these will fall into several categories: production, harvest, cost, and economic return.

\section{Production}

Expected availability of fry/smolts

Fry/smolt survivability by species and location

Weight gain/pound of food by species and location

Release goals by species and location

Cost

Cost per smolt received

Cost per smolt released by species and location

Cost per captured adult (all fisheries)

Cost per adult captured in terminal fishery

\section{Harvest}

Rates of interception by species and location

Number of project fish contributing to all fisheries

Number of project fish contributing to terminal fisheries

Rates of return by species and location

Rates of straying by species and location

\section{Economic Return}

Percent of harvested project fish for which poundage assessments are paid

Ex-vessel price by species and location

Dollars contributed to project through poundage assessments

Percent of total project funding from poundage assessments

Total economic contribution by community, region and state

A goal for each category should be established every year. An annual report would then

characterize the difference between goal and actuality. Done in a timely fashion, this report can be used to evaluate and adopt changes necessary for the next year's operations.

As other meaningful standards are recognized, they should be immediately included. 


\section{Section 5}

\section{Organization}

- Form of Organization

- Policy Issues 


\section{MANAGEMENT OPTIONS FOR LOWER RIVER SALMON ENHANCEMENT PLAN}

The purpose of this section is to explore options for managing and administering the expanded terminal fishing project. Each option is analyzed using a pros and cons approach. The listing is random and not related to any priority. The final page includes recommendations.

Any management scheme would probably need approval. perhaps legal. from:

- National Marine Fisheries Service which, under ESA guidelines, has authority over type and number of fish released.

- The states of Oregon and Washington which have direct responsibility for water quality, fish hatchery, salmon harvest and allocation, habitat, and naturally spawning fish protection concerns.

- The tribes who are co-managers of the basin's salmon resource.

- The counties of Clatsop and Columbia in Oregon, and Pacific and Wahkiakum in

Washington all of which are proposed to have projects located in their waters, and whose residents and economies would benefit from project success.

In addition, non-legal support will be necessary from:

- Northwest congressional delegation which will be instrumental in determining project success through funding and facilitating some plans.

- State legislative delegations for the same reasons listed above.

- Bonneville Power Administration, US Fish and Wildlife Service and the U.S. Army

Corps of Engineers all of which have some responsibility for river activities.

- A variety of smaller, mostly local, public agencies such as ports and economic development councils.

- Environmental leadership and groups.

- Other commercial fishing groups such as trollers, and charter boat operators, as well as non-salmon fisheries.

- Sport fishing leadership and groups.

\section{OPTION: Expanding Current CEDC Proiect}

This option would expand the Clatsop County Economic Development Council project at Youngs Bay, which has current working arrangements at Tongue Point, Blind Slough, and, indirectly, Deep River. The project is administered by Clatsop County.

Pros

- There would be no need to fashion some new program, just build on what exists.

- The administrative infrastructure is in place - bookkeeping/payroll, employee support and standards, salary structure, advisory board, oversight and accountability, experienced and capable staff, considerable knowledge - to make the program successful.

- The track record is exemplary with the program gathering accolades for years. It has been used as a model for similar projects.

- Funding has always been limited, so the project manager has found ways to do things in the most cost effective manner.

- The project is non-profit.

- An advisory Board exists, and oversight is done through the Clatsop County Manager and the County Commissioners.

- The State of Oregon already works closely with the Youngs Bay project and staff.

- The Bonneville Power Administration has worked closely with the Youngs Bay project.

\section{Cons}

- Clatsop County would have to be willing to take responsibility.

- Other Oregon counties would need to align with the project.

- The role of Washington and its counties, and their ability to enter into a bi-state production project, would need to be defined. 
- Some might consider the administration too parochial if located in Clatsop County.

- Liability and insurance responsibilities, complicated by the bi-state nature of the project, would need to be researched and decisions reached.

\section{OPTION: Develop Columbia Riwer Estuary Study Taskforce (CREST)}

This option would seek to expand the responsibilities of CREST, an existing lower river, bi-state council of governments supported by counties and ports.

Pros

- Expands an already existing program that has legal status and is supported by agencies in both states. Not necessary to start something new.

- CREST has earned a reputation for good research toward management of natural resources.

- Board of Directors is already in place.

- Administrative infrastructure is in place.

- Ability to handle grants and to seek and utilize other funds is demonstrably good.

- Maintains local, grass roots supervision of project.

- Has ability to contract with CEDC Project for expertise and services as needed.

- Has tax status of 501-C3.

- As the administrative umbrella, CREST could contract with Clatsop County/CEDC, or others, for services as needed to make the program successful.

\section{Cons}

- CREST has been around for a long time and may have baggage that makes it unacceptable to some.

- Their task is primarily research, not management.

- Council of Governments must adhere to hiring, bidding and other practices of the public sector. This might slow down business decisions.

- CREST may not be willing to accept the responsibility.

\section{OPTION: Develop Existing Non-profit Salmon for All (SFA)}

Under this option, an existing, non-profit organization would be used to administer the project. Salmon for All is a trade association representing the commercial, lower river salmon industry, whose members would be the primary beneficiaries of this project.

Pros

- Salmon for All is already non-profit, doing its work in both states, and familiar with political and bureaucratic workings of both Oregon and Washington. Its tax status is 501 C6. It has a Board of Directors and by-laws. Its goals include working with all other salmon interests on behalf of the salmon.

- SFA, as the administrative umbrella, could contract with Clatsop

County/CEDC, or others, for services as needed to make the program successful.

- A 501 C3 tax status could be sought with a foundation established to support the project.

The foundation board would oversee the project.

- SFA is familiar with industry needs.

Cons

- As a politically active entity, SFA could carry baggage that might affect its ability to pull together all interests.

- Some may be uncomfortable with a "commercial fishing group" providing administrative support.

- Some may be uncomfortable with personalities within SFA.

- SFA may not be willing to accept the responsibility.

\section{OPTION: Develop New Bi-state, Non-profit Structure}

This option would have participatory agencies, primarily ports, counties and states, in cooperation with the fishing industry, develop the administrative framework for the production plan. 
Pros - The agency stakeholders would be at the table. This would include local and state elected officials and bureaucrats whose combined efforts could develop such a bi-state structure.

Cons - Some new scheme, agency or group would have to be developed. All roles of involvement and responsibility would need to be defined. Legal papers would need to be drafted, and a non-profit status sought.

\section{OPTION: Develop a Bi-state Council of Governments}

This option would cause the legally involved agencies to develop a working relationship equal to or similar to a council of governments.

Pros

- Such a structure would assure and define participation by the agencies.

- It would have its own identity, goal and tasks.

- Examples are available for emulation. Not breaking new ground.

Cons

- It would mean creating something new and developing another government agency.

- Some may be unwilling to participate in a COG.

- In some ways, would duplicate that which has already been

developed in CREST.

\section{Recommendation}

- CREST administer the lower river production project, provide administrative support, write grants, work with state and federal agencies on funding, policies and procedures.

- CEDC Fisheries Project be contracted by CREST to operate the actual production facilities, assist in budget development, hire/fire staff, work with state and federal agencies on biological issues.

- A commercial fishing advisory council, organized through Salmon for All, would advise represent CREST at compact, Technical Advisory Committee (TAC) and other harvestrelated forums, discuss ideas with state and federal elected officials.

\section{Administrative Option}

Based on the above recommendation, what follows is one way an organizational chart might look.

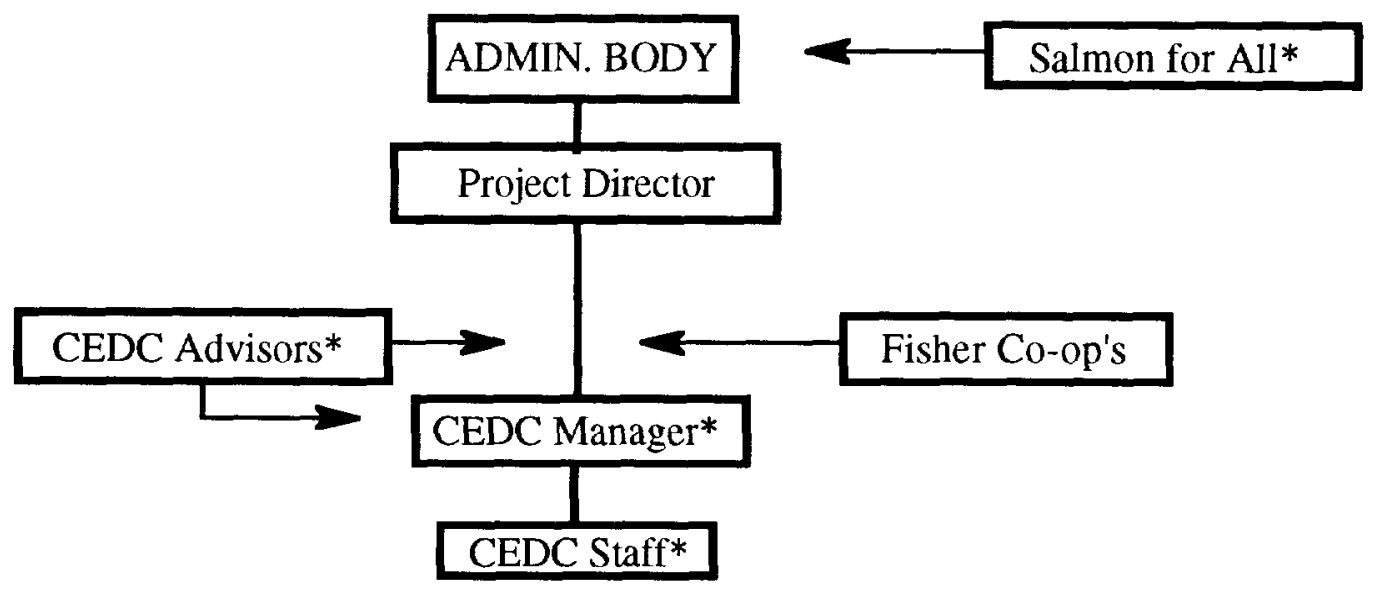

*indicates already exists 


\section{Section 6}

\section{$\underline{\text { Marketing and Economics }}$}

- Source of Funds

- Market Overview

- Executive Summary

Market Potential

Financing Plan

Economic Contribution 


\section{SOURCE OF FUNDS}

The Radtke report which follows provides full and complete cost analysis. The task of this section is to explore options available to secure the funding necessary. Identified here are four areas of funding nced. The first is up-front capital construction needs for development of net pen sites, and to purchase needed equipment and supplies. The second is up-front administrative funds to provide office facilitics and equipment, and staff with which to implement a management agenda necessary to get the program off the ground. The third includes funds to staff and maintain the production facilities and to care for the fish. The fourth is for on-going support of the program once harvestable numbers of fish are produced and the harvest beneficiaries provide income to the program.

As previously noted, salmon fishing is a public/private partnership. So the attempt here is to consider both separately, and in combination, for funding.

\section{Capital Development....estimate $\$ 3.5$ million over seven years or less}

Up fronts costs will be incurred before planned revenues from fishing will be available to the program. That's the nature of fishing because of the salmon life cycle. Since two proposed salmon recovery plans call for development of terminal fisheries, it is believed federal funds should be made available for initial infrastructure and capitol development investments. Radtke proposes a phased program for this. (Section 6, Executive Summary, pgs. $11 \& 12$ ) The sooner facilities are built and put into production, the sooner fishing income will become a reality.

These appear to be the funding choices, not necessarily by priority:

Mitchell Act - Established in the 1930's to support the region's fisheries in the wake of expected salmon destruction by the developing hydro-electric system on the Columbia. Funds were to mitigate for salmon loss. Over the years, this has meant federally appropriated funds for federal and state operated hatcheries. The Act exists as a funding mechanism as long as Congress allocates money to it. The Act has in recent years been underfunded and with the new Congress it no longer enjoys the political support it once had. State, NPPC, NMFS, tribal and congressional support would be needed to gain funding through the Mitchell Act.

Bonneville Power Administration - BPA continues to have a financial responsibility for salmon recovery efforts, responsibility that outstrips it finances. Terminal fishery development would have to be made a recovery priority to be eligible for limited BPA funding. The NPPC would be instrumental in determining and recommending recovery priorities to BPA. State, tribal, NMFS, and congressional support would be needed, as well.

Interiurisdictional Fishing Act - Another federal act with funding to assist fisheries. Some elements of the terminal fishery plan might be eligible for funding. Competition for these limited funds would be national. NMFS and congressional support would be needed.

Others - Special congressional allocation; special budget consideration from NMFS; support from either or both Oregon and Washington legislatures; grants from private foundations and/or trusts; Small Business Administration or other low cost loans. The Pacific States Marine Fisheries Commission may be a source of funding. It has a proven record of tapping funding sources for worthwhile projects.

\section{Administrative Funding....estimated at $\$ 125,000 /$ year for five years}

In addition to the sources mentioned above under capital construction, it might be that the states and counties would provide these funds.

Operations Funding....estimated at $\$ 1.4$ million/year for five years All possible sources have been mentioned above.

\section{Beneficiary Funding....estimated at $\$ 3.6$ million/year at full production}

One of the goals of the program is to become financially self-sufficient once costs are predominately for raising fish, and revenues come primarily from the fees paid by those who catch 
the fish. This success will come when a way has been found for each fishery to participate equally for the fish they access. We will explore this by fishing group, by area normally fished. Using the value assigned to the commercial gillnet fleet for these fish, each fish would generate an average of $20 \% /$ pound for the terminal fisheries project budget.

Some will say that because their state and federal funds are going into the production of these fish, no additional fees should be levied. There is precedent for levying such a fee. One can look at state and federal parks which are made possible through contributions by all tax payers. Those who wish to use the parks pay additional for that privilege. This closely parallels that which is proposed for use in terminal fishing areas.

Gillnet in the Columbia River - An agreed upon method of assessment has been in use for nearly two decades at the Young's Bay project. Each fisherman or woman delivering their fish agrees to have a predetermined amount per pound withheld from their payment by the processor/buyer. In Youngs Bay for the fisher that currently is $5 \%$ of the poundage value. This amount is matched by the participating processor/buyer, who handles the paperwork and sends a check for both contributions to the Youngs Bay project. Checks are sent bi-weekly or monthly depending on the bookkeeping system of the buyer/processor. The system works well with nearly $100 \%$ participation, in part because the local nature of the business allows easy access to who is buying fish. This makes follow-up and enforcement relatively simple.

Ocean Troller - Depending on species, both Oregon and Washington trollers will catch terminal project produced fish. While trollers in Oregon now contribute a poundage assessment to the Oregon Salmon Commission, Washington trollers do not. In addition, while it is easy to assess gillnetters because all, or most, of the fish they take will be terminally produced fish, that is not true for trollers. And it would be impossible to determine which of those fish caught by trollers are terminally produced. The challenge is to provide a simple mechanism so trollers can participate. Here are two possibilities:

- Estimate the number of troll fish caught that would be terminally produced. Multiply that by $20 \notin$ /pound and assess that amount equally and proportionately among the permit holders in the form of an additional fee collected by the state at time of permit renewal. For example, let's assume troll catch is estimated at 20,000 terminally produced fish for the season. If these are silvers at 6 pounds/fish, the total would be 120,000 pounds which when multiplied by the $20 \notin$ /pound assessment would provide $\$ 24,000$. Let's assume 600 troll permits were expected to be renewed. Each permit would be assessed an additional $\$ 40$ for silvers which would go to the terminal fish project. This procedure would need to be done for fall chinook caught in troll fisheries as well, with the appropriate amount added to the fee. The state would levy and collect this additional fee. There would be no question about voluntary participation by trollers and processor/buyers.

- Each year estimate the percent of troll catch that would be terminally produced. At each delivery, the poundage would be multiplied by that percentage to estimate the amount of terminally produced catch, then multiplied by $10 \notin /$ pound which would be withheld from the troller pay, matched by the processor/buyer for a total of $20 \% /$ pound, and a check mailed to the project. For example, let's assume $10 \%$ of the catch is expected to be terminally produced. Assume, also, a delivery of 200 fish, or 1200 pounds. At the estimated $10 \%$ terminally produced catch figure, the troller would be assessed on 120 pounds at $10 \notin /$ pound, or $\$ 12.00$ for the delivery. That amount would be matched by the processor/buyer for a $\$ 24.00$ contribution to the project. This would require no state involvement, and the transaction would take place with the flow of dollars related to catch, not permits. Participation would be voluntary and those more distant from the Columbia might be disinclined to be involved. Follow-up and enforcement in those cases could be difficult.

Recreation in Terminal Area - Each licensed fisher wanting to fish any terminal area would be required to pay a flat fee to purchase a terminal fishery stamp. It would be good in any of the terminal areas. The fee would be based on $20 \% /$ pound times the average number of pounds, 
all species, a recreational fisher is expected to catch in terminal fisheries in a year. If we assume its three spring chinook, two silvers, and three fall chinook, then that would be $3 \times 15=45+2 \times 6=12+$ $3 \times 17=51=108$ pounds. At $20 \notin /$ pound, that would mean a $\$ 21.00$ flat fee for the stamp which would be state issued. Charter boat skippers would pay by the pounds landed/trip when fishing in terminal areas. After some experience, this amount could be added to the price of the trip and passed on to the fishing client.

Another way of gathering the fee for non-charter fishers would be to establish check-in stations, similar to waterfowl stations, associated with each terminal area. Fishers would check-in and pay the $20 \%$ /pound fee on their catch. The voluntary nature of this concept, and the administrative costs of staffing a check-in station to collect fees might make this idea less desirable.

Recreation in Buov 10 or Lower River Area - Much data is available on these fisheries - data that should allow for the following computations. An estimate would be made of the percent of terminal production fish taken in these fisheries. That figure in pounds could be divided by the estimated number of anglers, and a number of pounds per angler arrived at. A flat fee lower river stamp could then be issued by the state for all who wish to fish these lower River fisheries. Charter operators would use the same percentage to apply to their actual catch statistics.

Recreation in Ocean - By using the same process as above, a flat fee could be determined for purchase of an ocean stamp to be issued by the state. The same percentage would apply to catch aboard charter operated vessels.

The financial support of all participating user groups will be critical to the success of the program. If only the gillnet fleet participates, Radtke suggests the assessment would need to be $20 \% /$ pound. Most feel that is too high. Given the current world salmon market the Columbia River product would not be price competitive.

States, the harvest groups and terminal fishery planners are encouraged to do all necessary to develop a plan for cooperative funding among user groups. The gillnet industry is not opposed to carrying the greatest load for financial responsibility since, under this plan, they are the greatest beneficiaries. But it is possible they will be unable to do it without the help of other user groups. 


\title{
LOWER COLUMBIA RIVER/YOUNGS BAY TERMINAL FISHERIES EXPANSION PROJECT
}

\section{STUDY OF AN EXPANDED SALMON SMOLT ACCLIMATION AND RELEASE PROGRAM IN THE LOWER COLUMBIA RIVER/YOUNGS BAY AREA}

\section{EXECUTIVE SUMMARY}

\author{
Prepared by \\ Hans D. Radtke, Economist \\ Yachats, Oregon \\ in association with \\ Shannon W. Davis, Planner \\ The Research Group \\ Corvallis, Oregon
}

Prepared for

Salmon For All

J anuary 1996 


\section{Table of Contents}

Page

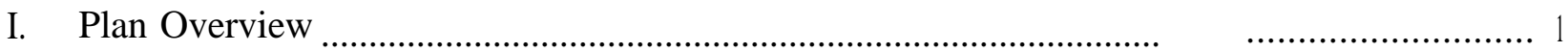

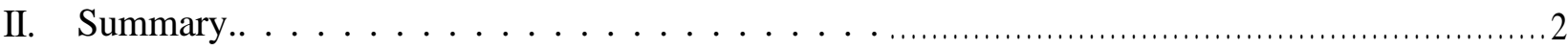

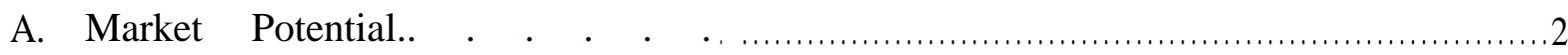

1. Historic Columbia River Salmon Production ................................................ .2

2. Present World Salmon Production of Captured Salmon ....................................... . . 2

3. Farmed Salmon ......................... ........................................................... 4

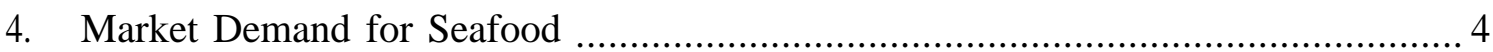

5. Market Opportunities for Columbia River Salmon ............................................ .5

6. Possible Future Markets for Columbia River Salmon ........................................... . .6

B. Financing Plan.. . . . . . . . . . . . . . . . . . . . . . . . . . . . . 7

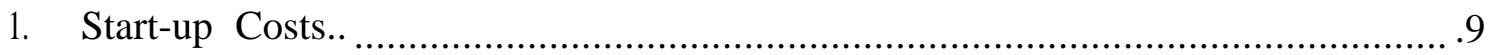

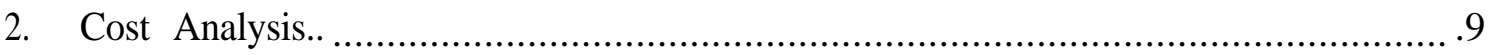

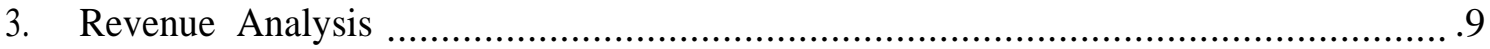





1. Economic Impact From Historic Salmon Runs.. ......................................... 12

2. Economic Impact of Expansion Project ….................................................... 14



4. Comparison of Costs, Ex-Vessel Revenues and Economic Income Impacts ........... 18

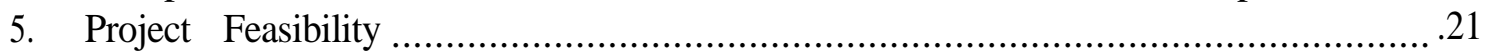

III. References.. . . . . . . . . . . . . . . . . . . . . . . . . 23

\section{LIST OF TABLES}

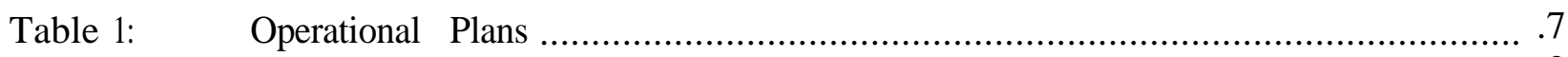

Table 2: $\quad$ Site Development Cost .................................................................. 9

Table 3: $\quad$ Stabilized Operation, Maintenance, and Replacement Costs for Mixed Species Operation Plan ..................................................................... 10

Table 4: $\quad$ Project Phasing ............................................................................... 13

Table 5: $\quad$ Full Development Financing Plan ............................................................... 14 


\section{Table of Contents (continued)}

\section{LIST OF TABLES (continued)}

Table 6: $\quad$ Estimated Contributions and Economic Income Impacts to Pacific Fisheries by Selected Species/Broods of Salmon Acclimated and Released at Lower Columbia River and Youngs Bay Sites By 100 Smolt Releases and Percent.. _. . . . 16

Table 7: $\quad$ Estimated Costs per Smolt for the Lower Columbia River/Youngs Bay Terminal Fisheries Expansion Project by Species . . . . . . . . . . . . . . . . 18

Table 8: $\quad$ Ratios of Lower River Columbia Salmon Acclimation and Release and Hatchery Costs to Ex-Vessel Revenues . . . . . . . . . . . . . . ... . . . . . . . . . 19

\section{LIST OF FIGURES}

Figure 1: $\quad$ Estimated Average Volume (Weight) of Captured Salmon by Area .................... .3

Figure 2: $\quad$ World Salmon Supplies, 1987-1995 …............................................................. 4

Figure $3: \quad$ U.S. Per Capita Consumption .................................................................... $\quad .5$

Figure 4: $\quad$ Site Location Map ................................................................................ 8

Figure 5: $\quad$ Itemized Shares of Stabilized Operation, Maintenance, and Replacement Costs for Mixed Species Operation Plan ....................................................... 11

Figure 6: $\quad$ Stabilized Annual Operation, Maintenance, and Replacement Costs .................. 11

Figure 7: $\quad$ Historical Columbia River Estimated State Income Impact ............................. 15

Figure 8: $\quad$ Total Statewide Personal Income in West Coast Geographic Areas Attributable to Columbia River Acclimated and Released Salmon:

Commercial and Sport Fisheries 


\section{EXECUTIVE SUMMARY}

\section{Plan Overview}

A plan was developed to expand the Clatsop Economic Development Council (CEDC) Fisheries Project. The plan is referred to as the Lower Columbia River/Youngs Bay Terminal Fisheries Expansion Project. The goal of the expansion is to increase the commercial and recreational harvest of hatchery fish while providing greater protection of wild salmon stocks.

The advantage of this program is in the expected increase in marine survival rates of smolts to harvested adults. These marine survival rates are estimated to be 1.77 greater for chinook and 2.33 greater for coho. This project, working in concert with existing Columbia River hatcheries that operate because of mitigation agreements, will be able to finish raising and releasing smolts at comparable existing hatcheries.

A market exists for fresh salmon, although preferences for product forms are changing. Fresh fish products will have the advantage of coming to market in a less competitive time period. It is recommended a marketing program containing quality assurance from harvest to retail sales be used. This will assist in maximizing sale prices for this price sensitive commodity.

If this project is viewed as a substitute for other releases, additional harvesting revenues and regional personal income may be generated. The 57 million smolts that are to be released in an expanded acclimation and release project may generate an additional \$11 million of revenues for gillnet harvesters. The lower Columbia River communities would benefit from an additional $\$ 19$ million of total personal income generated by the gillnetting and the lower river recreational industries, while the West Coast economy may gain a total of $\$ 49$ million of income generated by the commercial and recreational fishing industries.

A financial support program of around $\$ 15$ million will be required to pay for capital construction and for feed and other annual operating costs. As salmon return, the acclimation and release program may be self supporting when assessments are instituted for recreational and commercial fishing beneficiaries. This assumes that husbandry and marking costs are borne by historic hatchery programs. A suggested amount for the assessments on gillnetters' revenue and equivalent assessment or government general fund support for the recreational anglers is made as part of the proposed financial plan. 


\section{Summary}

\section{A. Market Potential}

\section{Historic Columbia River Salmon Production}

The salmon from the Columbia River system have always been a source of food and income for residents of the Pacific Northwest. Salmon, to the Indians living along the Columbia River, was their lifeblood, essential to their subsistence, their culture and their religion. The first (non-Indian) use of the fishery products in Oregon was the packing of salmon. Development of the canning process in the mid 1800's created a huge demand for salmon, and the lower Columbia River became the West Coast center for the packing industry.

In 1892, for example, the total amount of pounds landed in the Columbia River was 33.5 million pounds, valued at about $\$ 1.1$ million. At today's approximate prices, these 1892 landings would be valued at about $\$ 87.6$ million. For example:

Chinook (mostly spring chinook, caught April, May)

Sockeye

Steelhead

Silver
@ $\$ 3.00$

@ $\$ 2.50$

@ $\$ 1.00$

@ $\$ 1.00$
$\$ 69.2$ million

$\$ 13.3$ million

$\$ 4.6$ million

$\$ 0.4$ million

$\$ 87.6$ million

Total

Total pounds of salmon (and steelhead) utilized commercially in the Columbia River were as high as 46 million annually in the late 1910's and early 1920's. In more recent times the Columbia River has produced around 20 million pounds annually until the late 1940's. Since then the total poundage harvested has generally declined to its lowest level in 1993, when a total of just one million pounds of salmon were harvested commercially in the Columbia River.

\section{Present World Salmon Production of Captured Salmon}

As harvesting, processing and marketing technology has changed over time, so has resource production. With improved transportation, canning and cooling technology, much of the U.S. wild salmon production has moved to Alaska. In 1994, Alaska produced 390,000 metric tons (MT) of salmon.' This is about 40 percent of all of the 857,000 MT captured salmon in the world in 1994 (Figure 1).

Chinook and coho are not as abundant in the open ocean as are sockeye, pink and chum. Captured chinook were about 2.7 percent of the total in 1994, while coho accounted for about 8 percent (Figure 1).

1. A metric ton equals 2,205 pounds. 
The lower 48 states in the U.S. produced about 2.7 percent of the total captured salmon. In terms of the more specific species, about 12,000 MT of chinook and 40,000 MT of coho are captured in the world annually, of which the lower 48 states produce about seven percent.

\section{Figure 1}

Estimated Average Volume (Weight) of Captured Salmon by Area

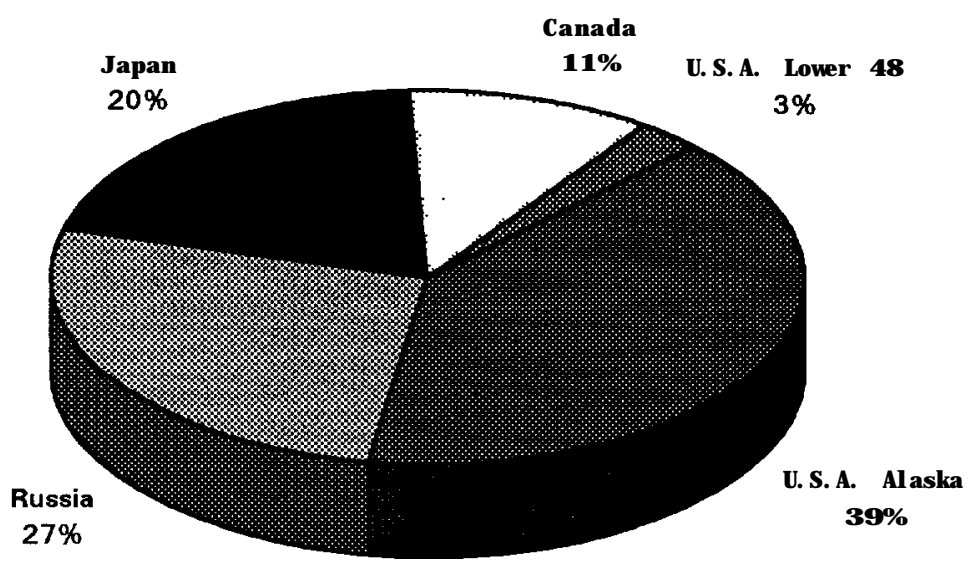

Estimated Average Volume (Weight) of Captured Salmon by Species

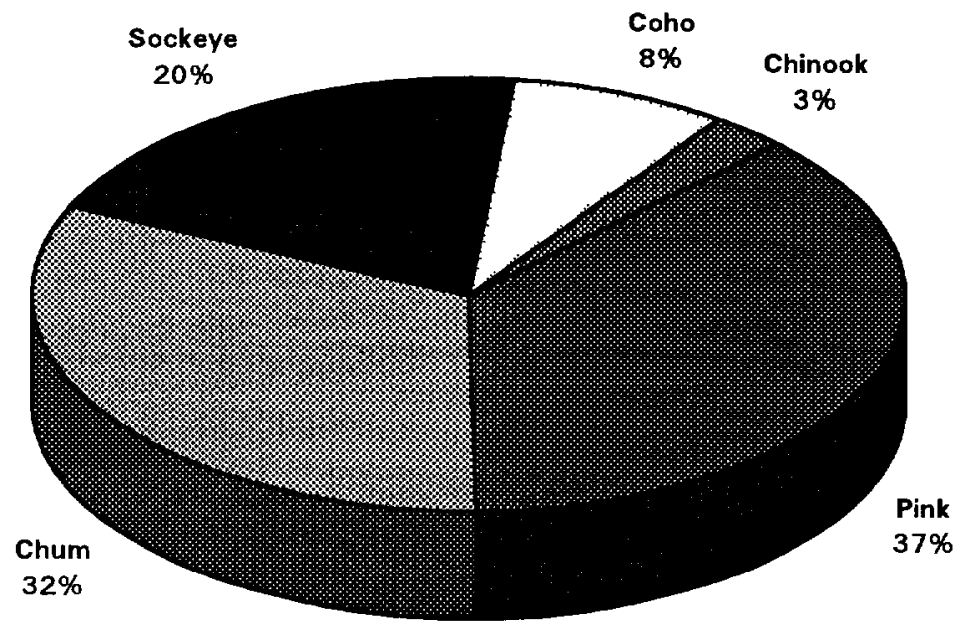

Sources: Study and Alaska Seafood Marketing Institute 1992; Canadian Department of Fisheries and Oceans; Alaska Department of Fish and Game 1995; Pacific Fishing, March 1995; estimates of Japan and Russia are from Alaska Seafood Marketing Institute, 1995. 


\section{Farmed Salmon}

With improved feed and disease control, a significant part of the total world salmon supply is now being produced by pen rearing. In 1995 aquaculture will produce about 40 percent of the total volume of salmon produced in the world. This is a dramatic shift from 10 percent in 1987 (Figure 2).

Figure 2

World Salmon Supplies, 1987-I 995

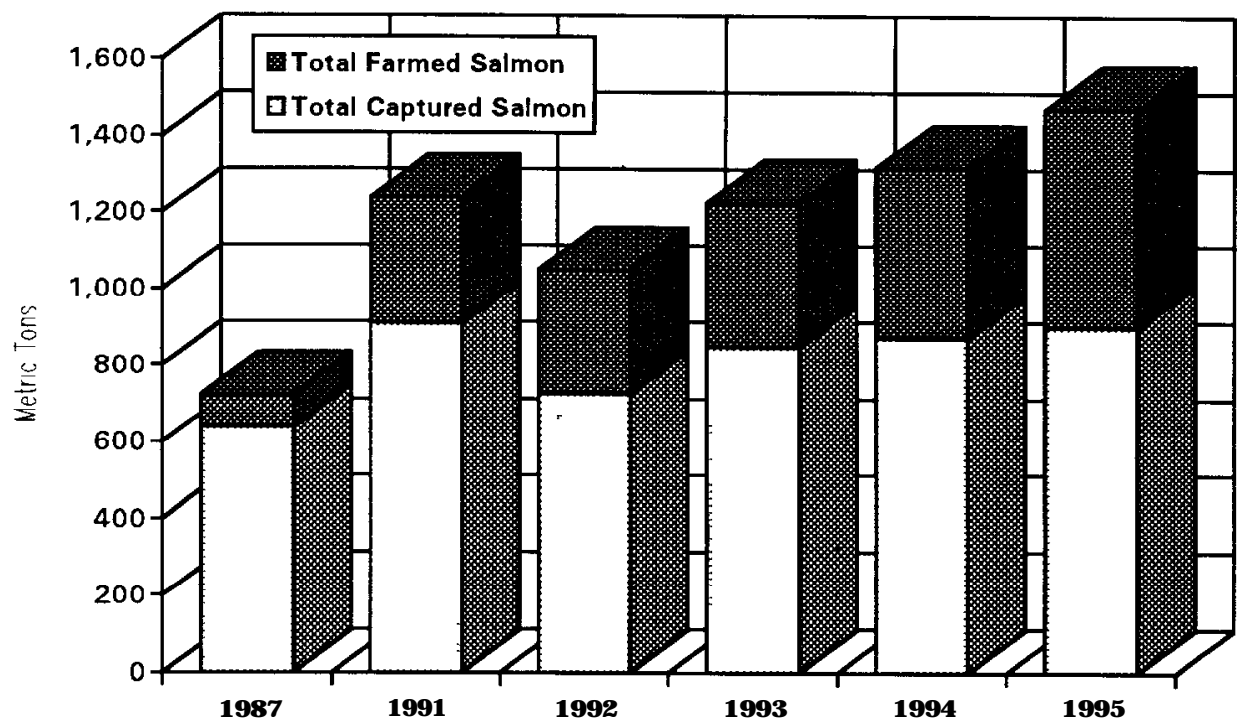

Sources: Washington Farmed Salmon Commission, January 1995. Currents: A Journal of Salmon Market Trends, June 1995.

Notes: 1995 estimates are based on the study assumption that 1994 captured salmon would be at 900 metric tons and that farmed salmon production will be at 571 metric tons.

About 75 percent of the farmed salmon produced are Atlantic salmon. Chile, Japan and Canada produce the bulk of the farmed coho. Canada is the only significant producer of farmed chinook.

\section{Market Demand for Seafood}

In the United States, per capita consumption of red meat has dropped between 1970 and 1993 from 132 pounds per capita per year to 112 pounds. Poultry has taken a dramatic increase from 34 pounds per capita in 1970 to about 61 pounds in 1993. Seafood enjoyed a gradual increase in consumption with a record 16.2 pound per capita consumption in 1987, but this has gradually decreased to about fifteen pounds in 1994 (Figure 3). Since that time, per capita consumption has fluctuated around fifteen pounds per capita. Since 1970 real seafood prices increased 36 percent, while real prices of food in general declined by one percent. Real prices for red meat declined 17 percent while real prices of poultry declined 31 percent. 
Figure 3

U.S. Per Capita Consumption

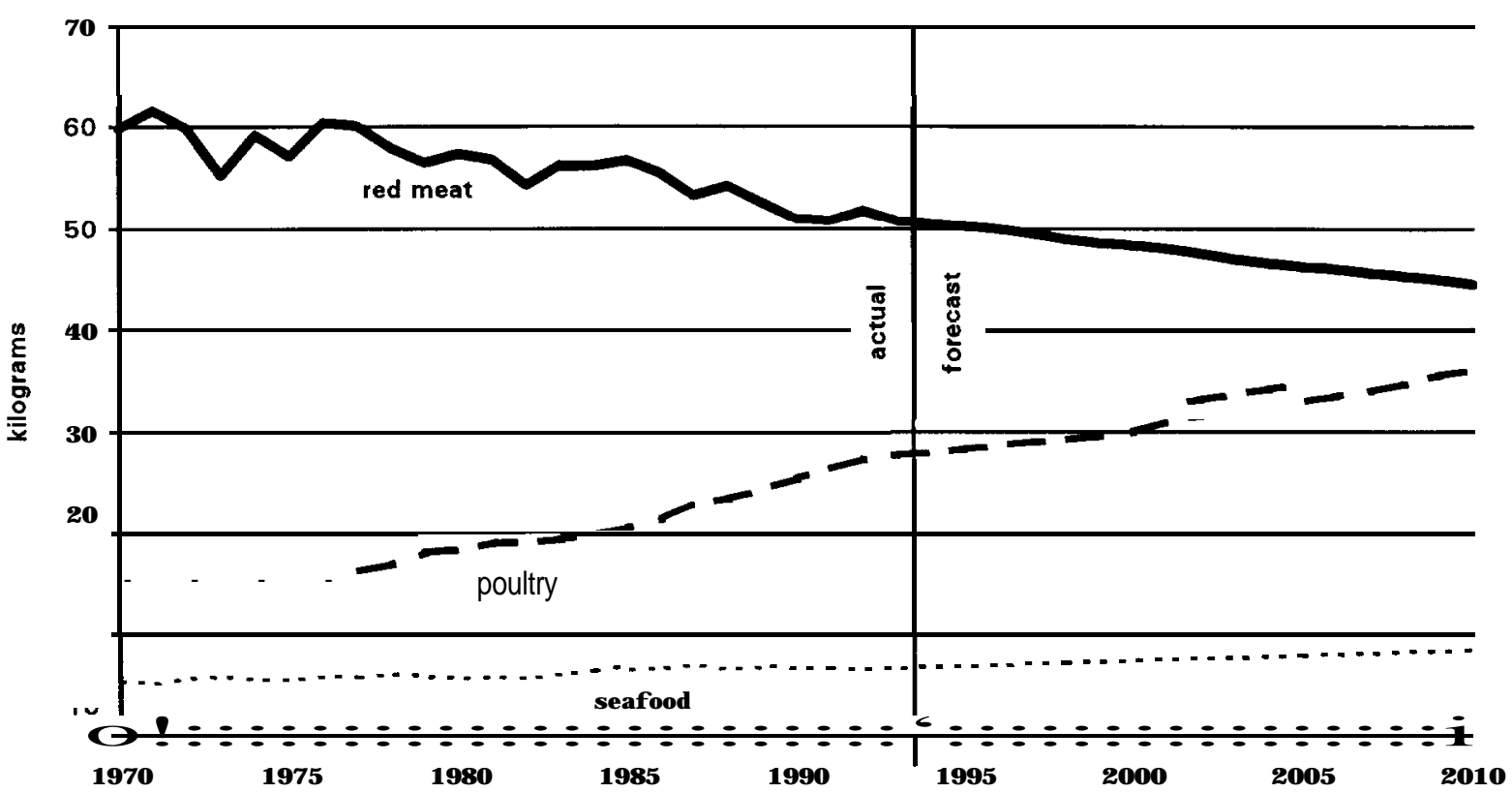

Source: Anderson 1995.

Seafood has enjoyed a gradual increase in consumption in spite of real own price increases and relative to other protein sources price increases. Much of the increase in consumption has been due to the availability of fresh and frozen seafood, and the publicity that the industry has received concerning the "healthiness" of seafood.

The trend toward greater fresh/frozen consumption of fish has been mostly due to the growth in aquaculture. The increase in salmon from 1987 to 1993 was 130 percent.

Salmon, predominantly fresh/frozen and increasingly aquaculture produced, has enjoyed growing popularity in the U.S. Consumption of salmon has increased from 0.43 pounds per capita in 1987 to 0.99 pounds per capita in 1993 and to 1.11 pounds in 1994. Salmon rose from the eighth to the fifth most popular seafood between 1989 and 1993 and is considered to be one of the best sellers for U.S. restaurants and U.S. retailers.

\section{Market Opportunities for Columbia River Salmon}

It is expected that fresh and frozen seafood consumption will continue to comprise an increasing share of per capita consumption. Some of the reasons are:

1. Decline or stabilization of wild fish stocks in the world and in the U.S. 
2. Aquaculture prices are near or below the cost of production. World fish meal production is expected to decrease and therefore prices of fish food will increase. This major cost in salmon aquaculture and the expected future inclusion of environmental costs will increase the price of farmed salmon.

3. Portion-control products will continue to be an increasing share of the seafood market.

4. The continued popularity of eating out, coupled with moderately increasing income, should increase demand for seafood through the next decade.

5. Captured coho and chinook salmon from the U.S. make up less than three percent of global supplies of salmon (Oregon salmon catch is less than 0.3 percent).

6. Seasonal availability of fresh salmon from the Columbia River may have the advantage of being harvested in May and September/October, outside of the heavy summer captured salmon production period.

7. Price of harvesting and processing can be at or lower than farm produced salmon, especially if the economic returns from salmon eggs are included.

8. Spring chinook has seasonal and flesh qualities that are attractive to the consumer.

\section{Possible Future Markets for Columbia River Salmon}

Although supply of salmon has increased dramatically over the last decade, the demand for salmon as a food of choice has also increased. Preferences for product forms are changing. Marketing of quality seafood, harvested in the wild, with few environmentally sensitive problems, present an opportunity for Columbia River produced salmon. This is especially true for chinook that may be harvested in May or June, before the Alaska season, or later in the fall after most other season closures.

Some possible product forms are:

1. Coho: a. Fresh - local retail sales of fresh fillet and dressed

b. Frozen - overseas, head off, frozen, domestic value added products, commercial promotion

c. Other- value added fresh and frozen variable market forms, pickling, salted

2. Fall Chinook a. Fresh- West states fresh market, niche market for big fish which farms produce little of

b. Frozen - value added portions and products, smoked

c. Other - canned

3. Spring Chinook a. Fresh - seasonal opportunity is great and competition is weak during harvest (prime quality) season; retail, restaurants

b. Frozen - possible Japanese high fat market 


\section{B. Financing Plan}

Seven new release sites plus expanding the Youngs Bay release site are included in the proposed expansion plan. The various species or stocks of fish culture regimes considered in the expansion project are: lower Columbia River early coho (O ncorhynchus kisutch), Willamette spring chinook, Rogue River fall chinook, and upper Columbia River bright fall chinook (O ncorhynchus tshawytscha). These species or stocks were considered as the most viable for meeting project goals.

The seven new sites (see Figure 4 for site location) were winnowed from an original list of 25 candidate sites. Using rearing and harvest criteria, the final new sites to be considered in the expansion plans are:

- Tongue Point (Oregon)

- Blind Slough (Oregon)

- Deep River/Grays Bay (Washington)

- Clifton Channel (Oregon)

- Steamboat Slough/Skamokawa Creek (Washington)

- Wallace Slough (Oregon)

- Cathlamet Channel (Washington)

The existing Youngs Bay (Oregon) site would also be considered for additional production. Table 1 shows the preferred operational plan.

The financing plan reviews the start-up costs for adding the new sites to the CEDCFP and the annual operating costs for husbandry, transporting, acclimating, and releasing the fish. Sources of revenue to cover capital and operating costs are also discussed in this section.



Notes: Millions of smolts.

Source: Study and Jim Hill personal communication, July 1995. 


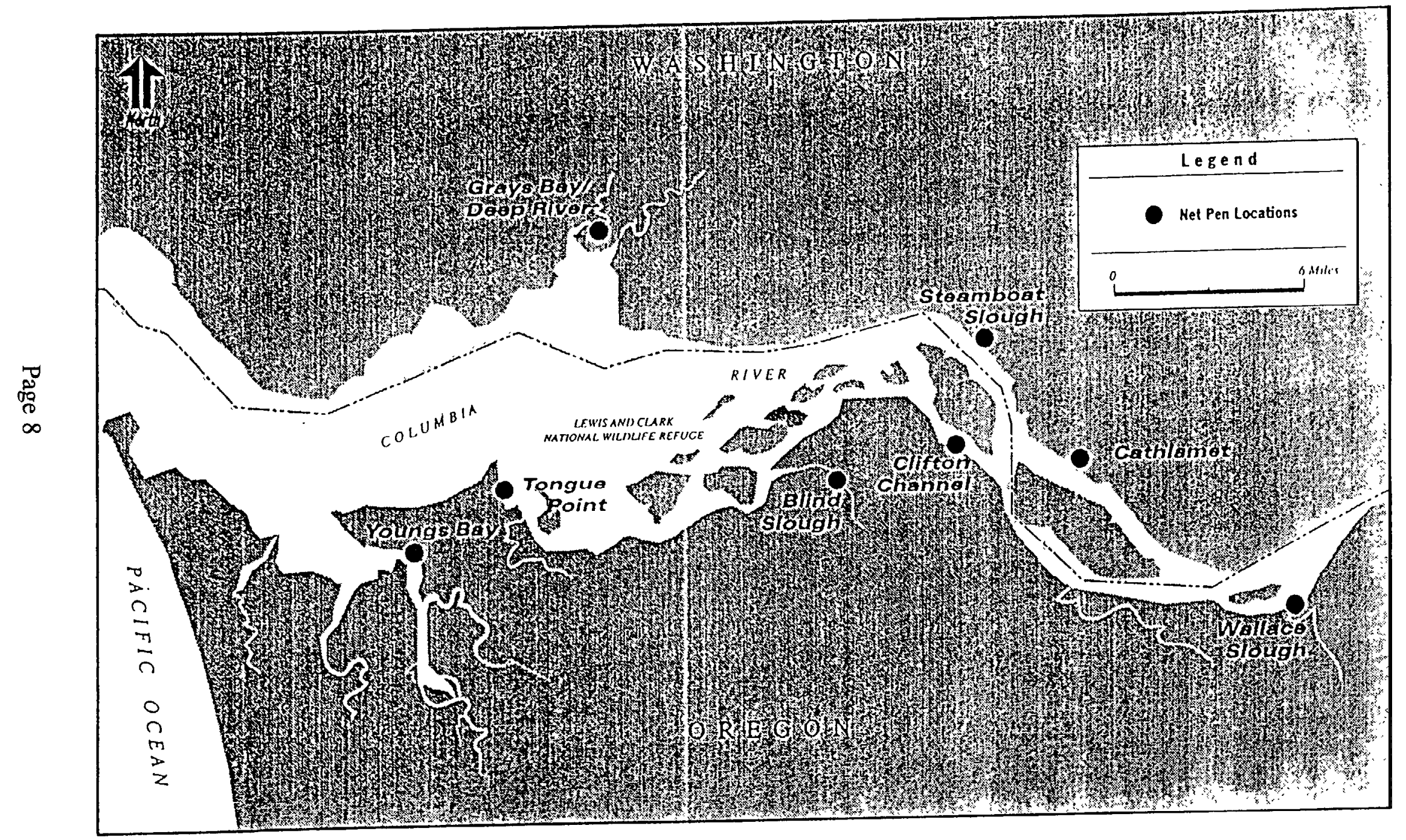




\section{Start-up Costs}

The start-up costs include the capital costs of improvements to the sites, some central costs that are not easily allocated to site improvements, and the set-aside of working capital to be drawn upon until revenues from assessments materialize. Table 2 describes estimated capitalized costs for each site. This table assumes an expansion size in the lower range of the number of new pens that can be installed at each site as determined from the Lower Columbia River Terminal Fisheries Research Project.

\section{Cost Analysis}

The stabilized operation and maintenance (O\&M) costs summarized over all sites for a production alternative of 57.0 million smolts is shown in Table 3 and Figures 5 and 6 . The allocation of O\&M costs to specific sites is based on either feeding days, smolt transport weight, or total expected smolt production from that site, depending on which is most applicable for the itemized expense.

\section{Revenue Analysis}

Project revenue requirements are itemized by initial capital improvements, working capital, reserve commitments, and operating income. The amounts necessary to finance the capital improvements are discussed in the Start-up Cost section above. Working capital requirements are assumed to be about two years of OM\&R costs. This amount should be sufficient to see the operations through the initial years until operating income from industry assessments are

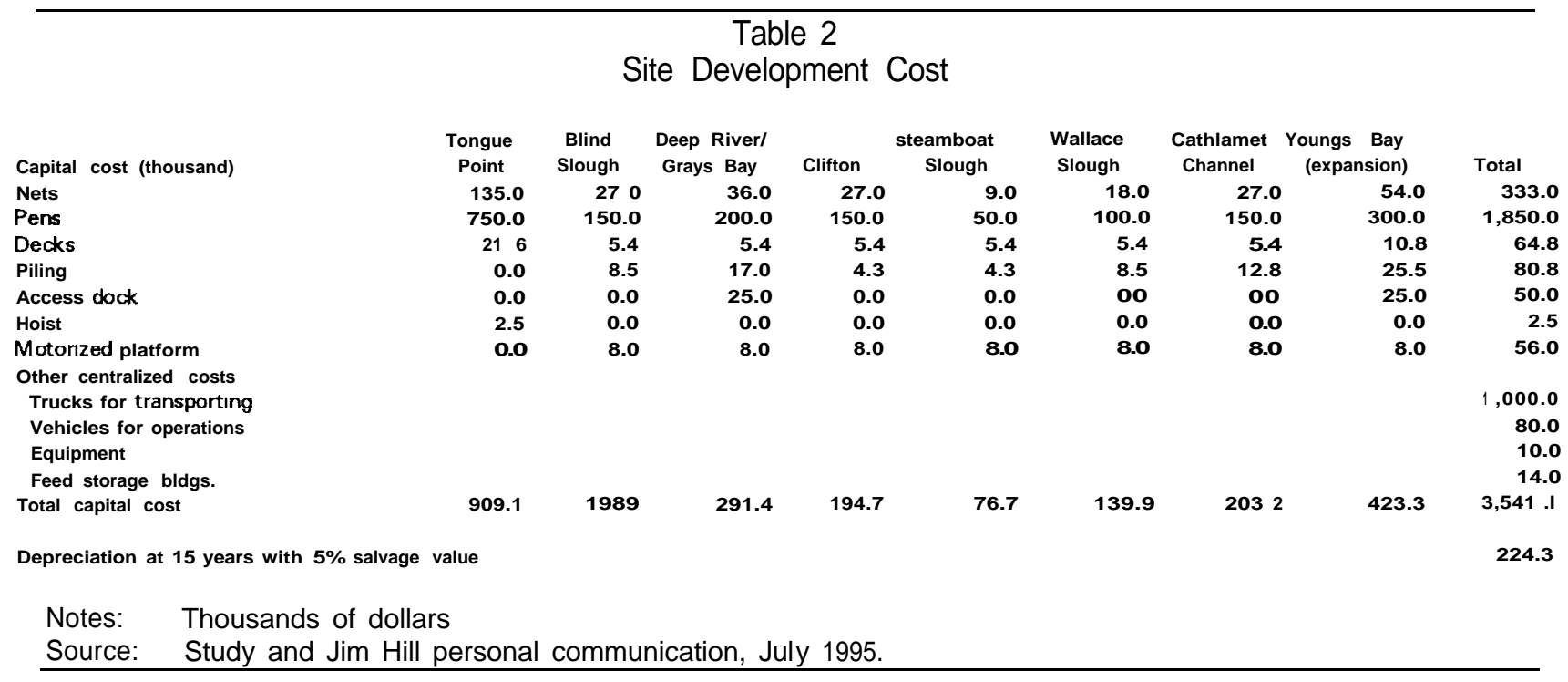


Table 3

Stabilized Operation, Maintenance, and Replacement Costs for Mixed Species Operation Plan

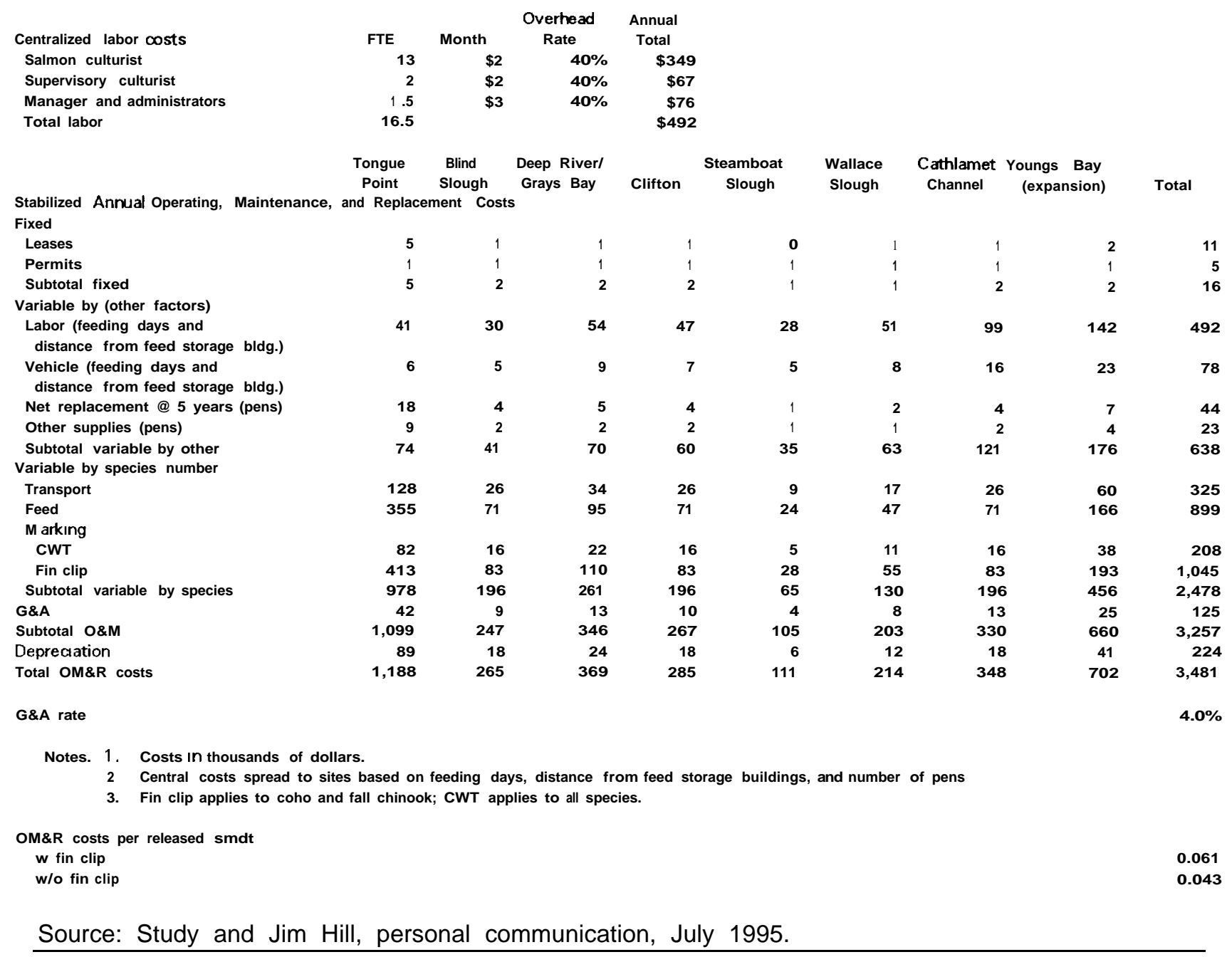

forthcoming. The reserve commitment is a prudent fiscal management fund. It would possibly be comprised of the following elements: variability in expected contribution to the gillnet fishery, licensing shut down responsibilities, financing debt coverages, insurance deductibles and maximums, and acts of force majeure.

Operating income is poundage fees assessed to the industry. The fees are assumed to double from their current $\$ 0.10$ per pound that is assessed at $\$ 0.05$ each to the harvester and processor. The rates of contribution to fisheries and expected average harvest weights are discussed elsewhere in this report. 
Figure 5

Itemized Shares of Stabilized Operation, Maintenance, and

Replacement Costs for Mixed Species Operation Plan

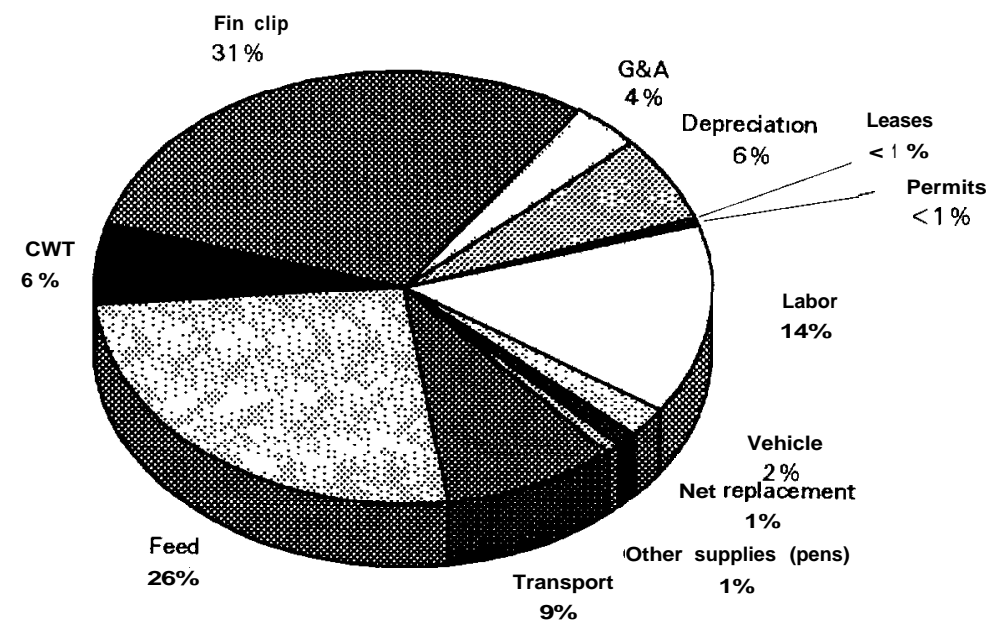

Figure 6

Stabilized Annual Operation, Maintenance, and Replacement Costs



Notes: Thousands of dollars.

Source: Study and Jim Hill personal communication, July 1995.

Page 11 
No connection of local, state, federal, or other program funding sources is made for the project revenue requirements other than the industry assessments. Other sections discuss project beneficiaries, such as recreational anglers and the deferred costs to donor stock hatchery operations. The latter is due to this project's feeding and husbandry during the acclimation period, which would have costs borne by hatcheries. Start-up and subsidization revenues could be considered as assessments to these and other non-industry beneficiaries.

\section{Project Phasing}

Development would depend on many factors, including the continued subsidization of hatchery production costs by outside funding sources. Development would also depend on the assumptions about start-up grant fund availability discussed in the Revenue Analysis section, above. A suggested development phasing of the proposed expansion project is shown in Table 4.

A pro forma for a full development plan is presented in Table 5 At the end of five years, there would be a carry over reserve of approximately $\$ 2.0$ million dollars. This amount is determined to be necessary considering the variability of commercial fishing assessments due to the unpredictable marine survival rate.

\section{C . Economic Contribution}

\section{Economic Impact From Historic Salmon Runs}

Historically, the Columbia River has provided jobs and income to thousands of harvesters, cannery workers, and employees in related industries throughout the region. Salmon numbers in the Columbia River Basin fell from between 10 and 16 million adults in the mid 1800s to about 2 million or less today. At today's prices this is equivalent to as much as $\$ 270$ million of income that would have been generated by these historic salmon runs. In 1993 the income produced by these runs has declined to about $\$ 2$ million (Figure 7). The reduction in commercial fishing jobs demonstrates only the direct effect of the contraction of the Columbia River based fishing industry. The associated decline in goods and services purchased from supply industries generates indirect impacts in the form of lost jobs and wages. Reductions in the spending of household incomes from this industry affects workers in the general regional economy; these are the induced effects related to the fishing industry.

The estimated 10 to 16 million fish that make up the pre-development Columbia River fish runs could have made available about 125 to 237 million pounds to harvesters on the Columbia River. At recent years' prices, at a 50 percent harvest rate, these landings may have the value of $\$ 136$ to $\$ 273$ million at the ex-vessel level. The harvesting, processing and related

activities of the Columbia River based salmon and steelhead fishery could generate $\$ 254$ to $\$ 507$ million of personal income annually. Most of this income would have resulted from the spring and summer chinook runs that have been decimated by the construction of dams and 


\section{Table 4}

Project Phasing

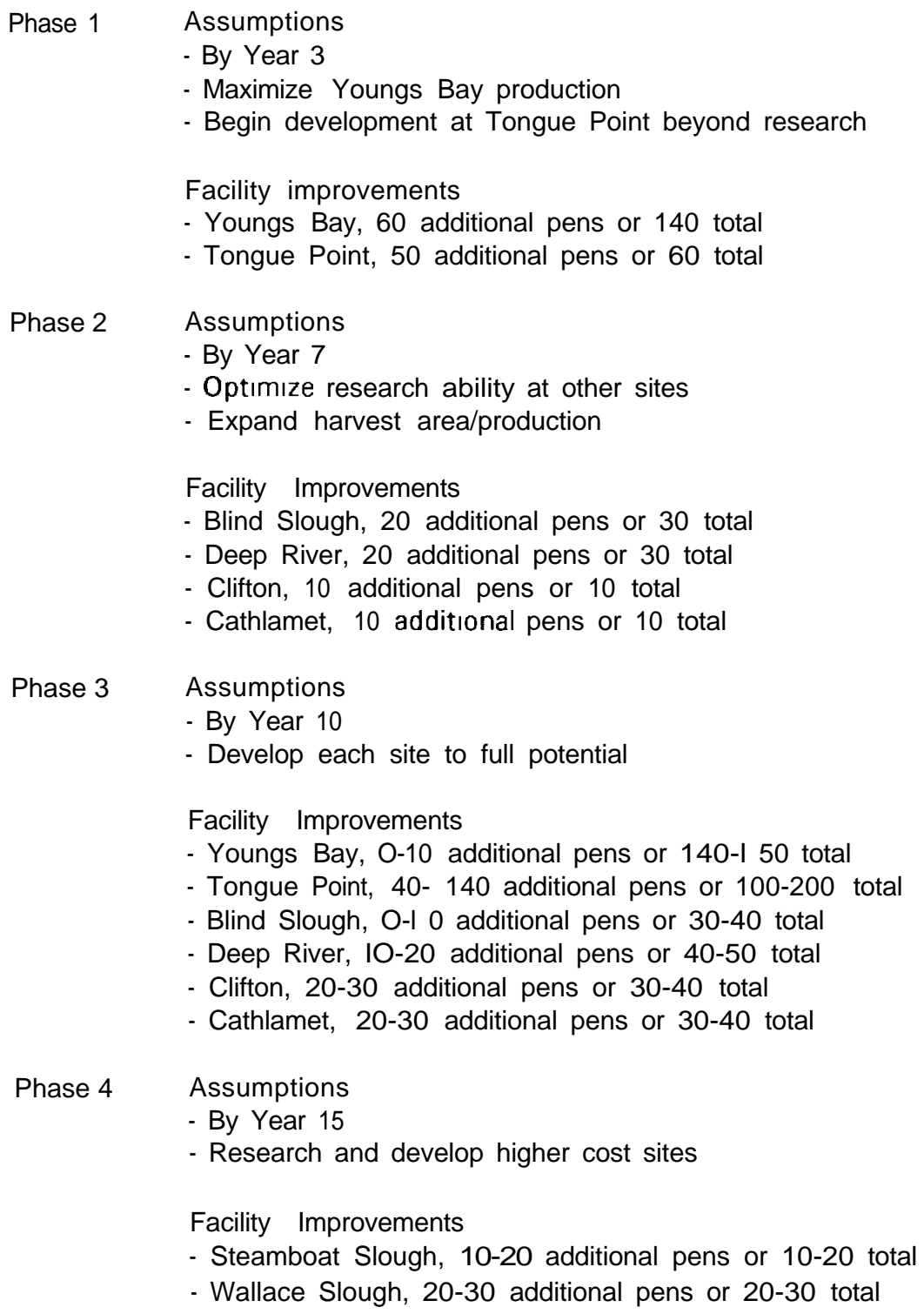

Phase 4 Assumptions

- By Year 15

- Research and develop higher cost sites

Facility Improvements

- Steamboat Slough, 10-20 additional pens or 10-20 total

- Wallace Slough, 20-30 additional pens or 20-30 total

Source: Study and Jim Hill personal communication, July 1995.

loss of cool water. At a $\$ 20,000$ full time equivalent wage or salary, this income could support from 13,000 to 25,000 jobs annually.

In general, the income received by business sectors in the fishing industry is about 40 percent harvesters, 30 percent processors, and 30 percent other support and general businesses in the region. Therefore, if commercial gillnetters on the Columbia River were the only harvesters of the Columbia River based salmon, they could expect \$102 million to \$203 million of income per year (based on pre-development runs). Persons employed in processing and in other supporting businesses could expect to generate about $\$ 76$ to $\$ 152$ million of income per 
Table 5

Full Development Financing Plan

Assumptions

- Development of 8 sites with 370 pens

- Optimal fishery contribution from returning adults (2.19 per 100 smolts for spring chinook, 3.09 early coho, 1.85 URB, .81 for Rogue chinook)

- Gillnet industry assessment doubled to $\$ .20$ per pound (17.06 lb for fall chinook, $15.6 \mathrm{lb}$ for spring chinook, $7.08 \mathrm{lb}$ coho)

- In-lieu of recreational assessments are available in annual grants in amounts necessary to defer operating deficits

Revenues (thousand)
Capital improvement grant
Working capital grant
Reserve grant
Commercial fishing assessments
Spring chinook
Coho
URB fall chinook
Rogue fall chinook
Other assessments
Total revenues
Expenditures
Capital improvements
Operating and maintenance
Total expenditures
Gross
Deprecration
Net
Cash flow
Annual
Cumulative

\begin{tabular}{rrrrr} 
Year 1 & Year 2 & \multicolumn{1}{r}{ Year 3 } & Year 4 & \multicolumn{1}{r}{ Year 5} \\
3,541 & 0 & 0 & 0 & 0 \\
6,962 & 0 & 0 & 0 & 0 \\
3,000 & & & & \\
& & & & \\
& 0 & 0 & 1,039 & 1,039 \\
& 0 & 1,330 & 1,330 & 1,330 \\
13,503 & 0 & 0 & 360 & 360 \\
& 0 & 0 & 158 & 158 \\
3,541 & & 2,105 & 3,661 & 3,661 \\
3,257 & 3,257 & 3,257 & 3,257 & 3,257 \\
6,798 & 3,257 & 3,257 & 3,257 & 3,257 \\
& & & & \\
6,705 & $-3,257$ & $-1,151$ & 405 & 405 \\
224 & 224 & 224 & 224 & 224 \\
6,481 & $-3,481$ & $-1,376$ & 180 & 180 \\
& & & & \\
6,481 & $-3,481$ & $-1,376$ & 180 & 180 \\
6,481 & 3,000 & 1,624 & 1,805 & 1,985
\end{tabular}

Notes: Other assessments are annual operating support that can be considered in lieu of recreational assessments and deferred costs to donor hatcheries.

Source: Study.

year. The businesses in the region that sell goods and services-to households that have received income from these fisheries affected businesses (the induced income) could also expect about $\$ 76$ to $\$ 152$ million of income per year.

\section{Economic Impact of Expansion Project}

Salmon that are released in the Columbia River system are harvested throughout the Pacific Northwest coast. Based on coded wire tag (CWT) information, the Columbia River Management Team made estimates of smolt to adult survival and contribution rates to fisheries throughout geographic areas of the West Coast. In addition to survival rates based on similar hatchery releases, a multiplication factor was used by the Columbia River Management Team to account for the survival rate of acclimated and released smolts. The increase in harvested adults per 100 smolts of these acclimated and released fish changes from 1.77 to 2.81 for 
Figure 7

Historical Columbia River Estimated State Income Impact

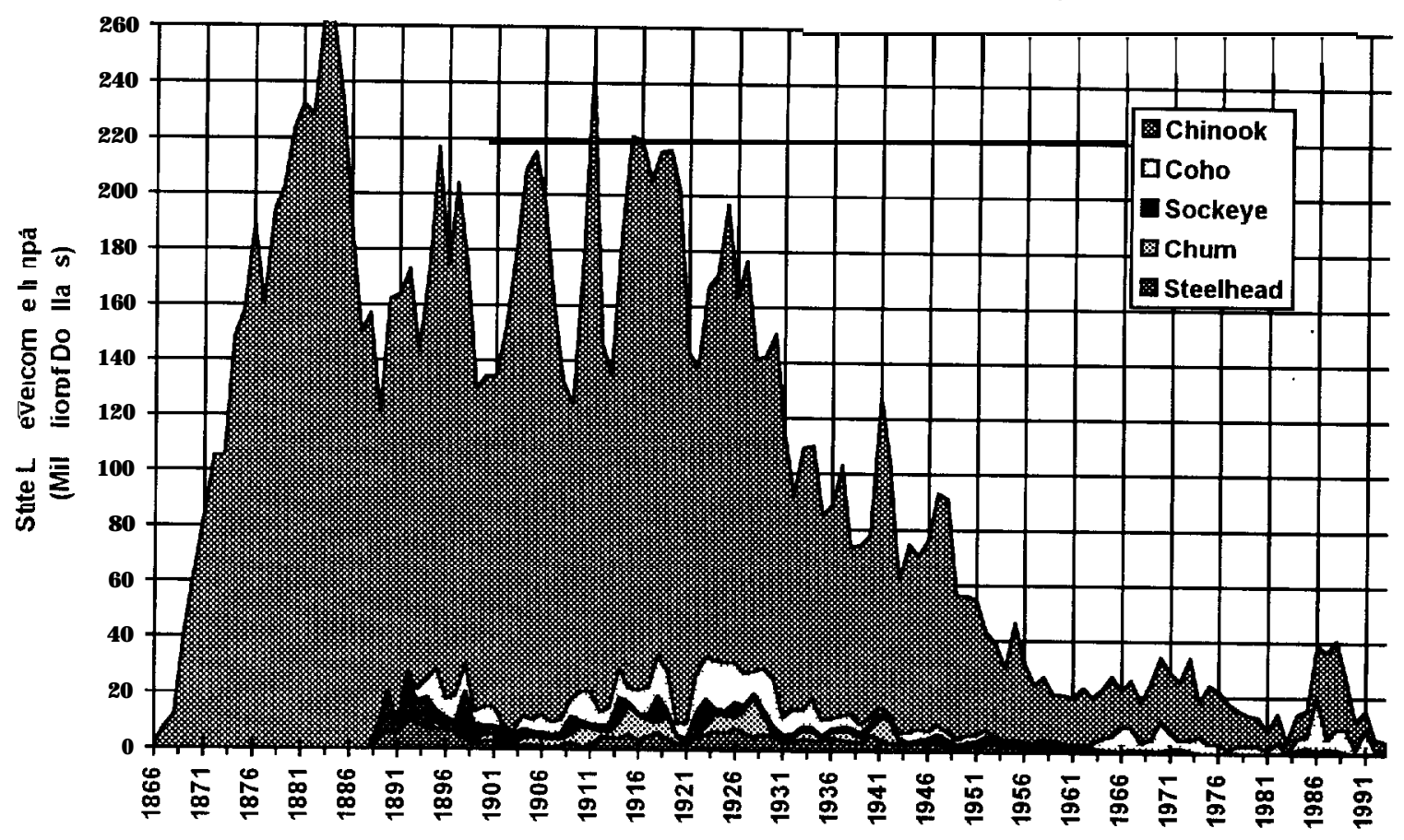

spring chinook and from 2.33 to 7.48 for coho (Table 6). Returns to the Columbia River gillnet fishery may vary from 0.81 for Rogue fall chinook to 3.09 for coho.

\section{Economic Impacts}

The economic impacts of activity related to harvesting salmon depend on many factors. The main factors are:
a) species of fish
b) price of fish
c) mode of fishing
d) geographic area of harvest
e) processed product

Based on existing economic models used to estimate both the commercial as well as recreational impact of salmon harvested on the West Coast, salmon acclimated and released in the lower Columbia River system may generate from $\$ 193$ to $\$ 276$ per 100 smolts acclimated and released (Table 6 and Figure 8). The contributions to the lower Columbia River economies from gillnet harvested fish may range from $\$ 134$ million ( $\$ 172$ million to state economies) for spring chinook to $\$ 37$ million ( $\$ 47$ million to state economies) for coho. 
Table 6

Estimated Contributions and Economic Income Impacts to Pacific Fisheries by Selected Species/Broods of Salmon

Acclimated and Released at Lower Columbia River and Youngs Bay Sites

By 100 smolt releases and percent

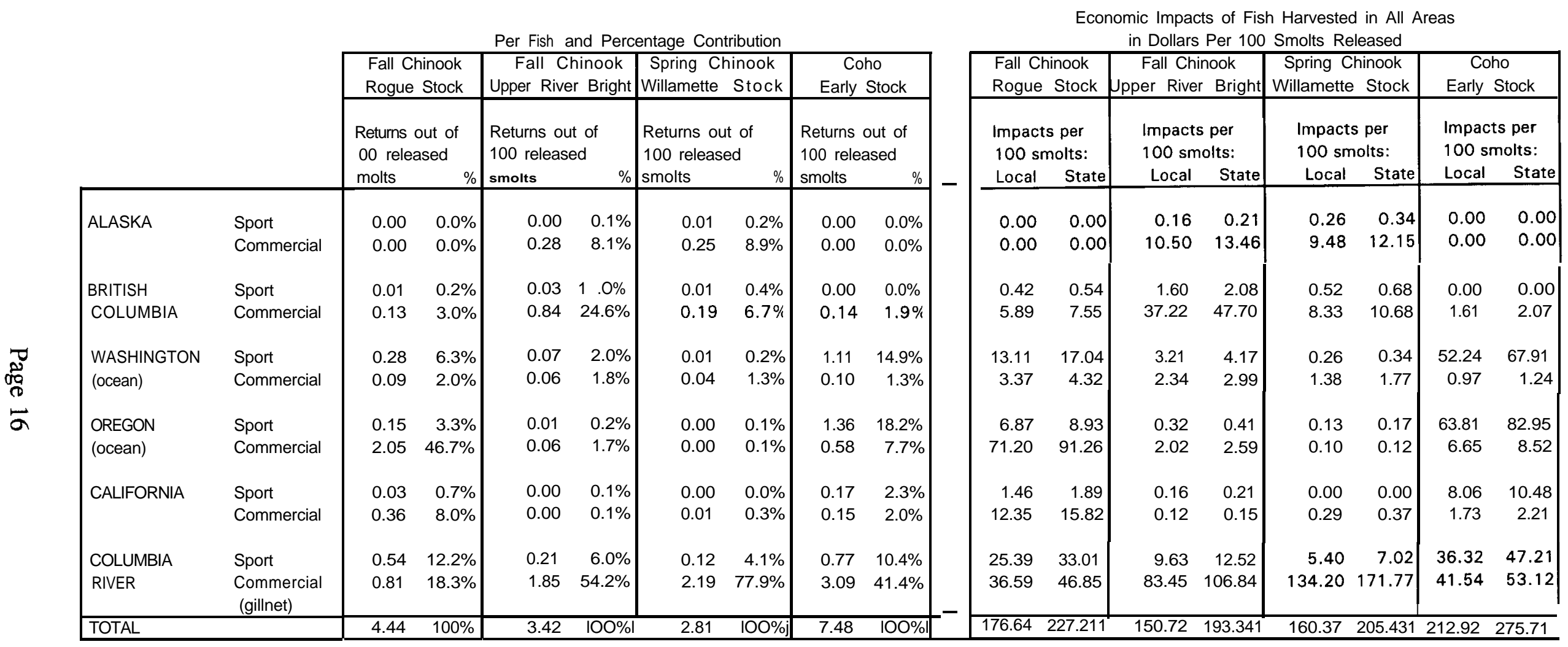

Notes: 1. Numbers may not total due to rounding.

2. The use of estimates to $7.48 \%$ (instead of rounding to $7.5 \%$ or to $7 \%$ ) does not indicate a strength in the accuracy. These survival rates were estimated by the Columbia River Management Team (ODFW and WDFW). The authors used these estimates as a calculating facility.

3. Per fish and percentage contribution estimates were calculated by the Columbia River Management Team (lead personnel Paul Hirose of ODFW and Marc Miller of WDFW), based on Coded Wire Tag information. Calculations and explanations are included in the Appendix.

4. For economic impacts of fish harvested in areas, estimations use the U.S. Forest Service IMPLAN Input/Output models and the Fisheries Economic Assessment Model developed by William Jensen and Hans Radtke. 


\section{Figure 8}

Total Statewide Personal Income in West Coast Geoaraohic Areas

Attributable to Columbia River Acclimated and Released Salmon: Commercial and Sport Fisheries

Fall Chinook (Upper River Brights)



\section{Columbia River Coho}

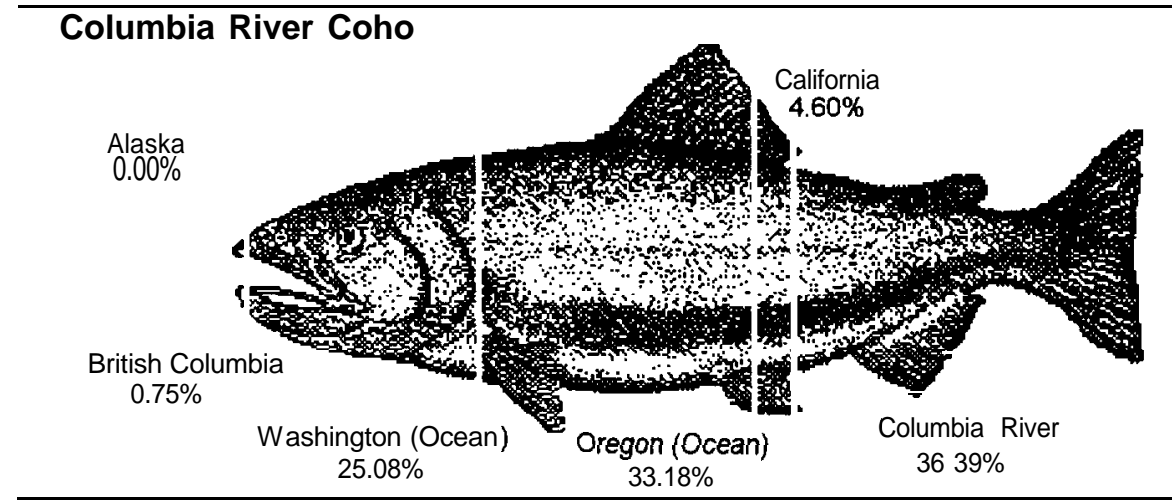

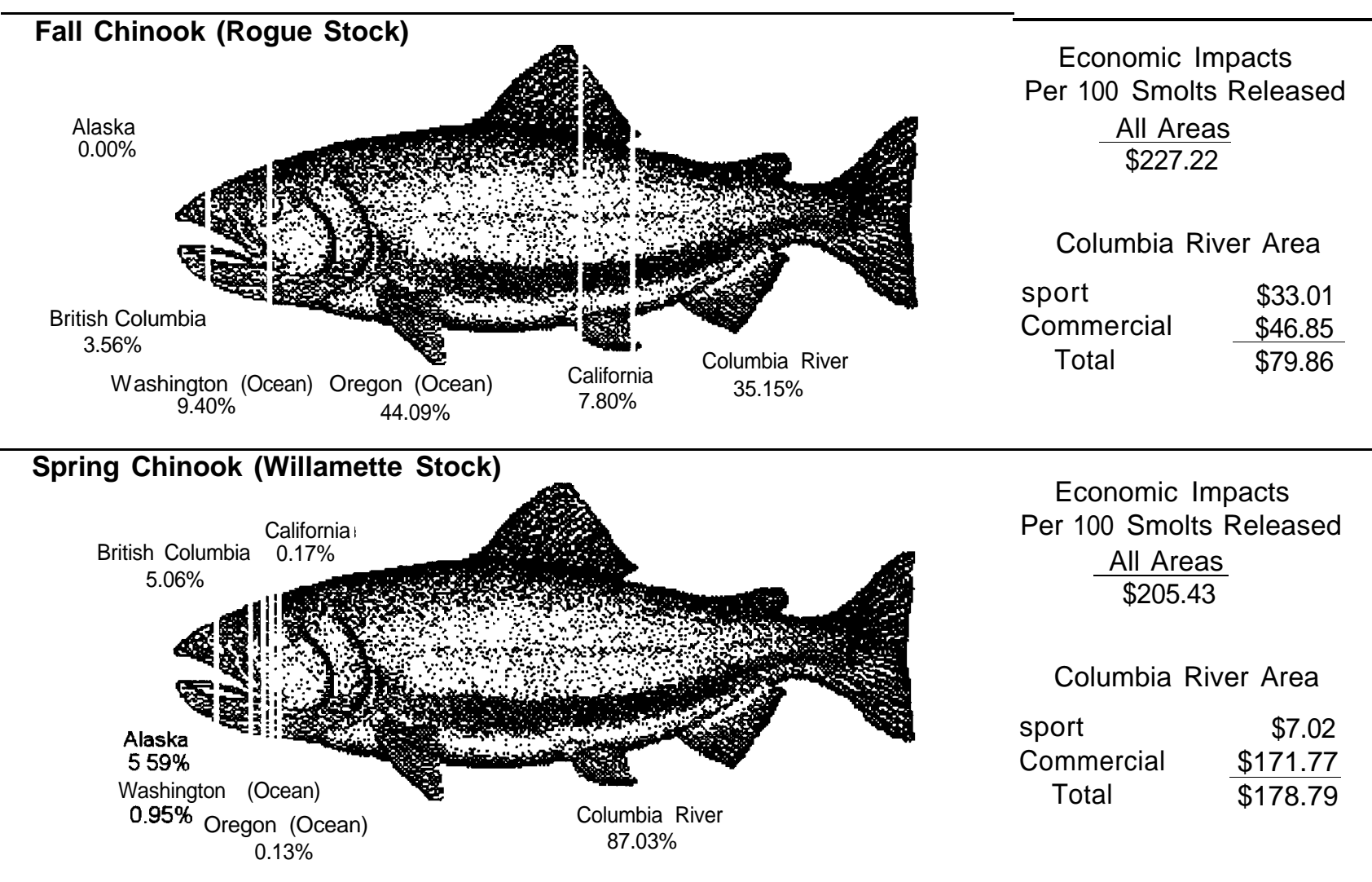

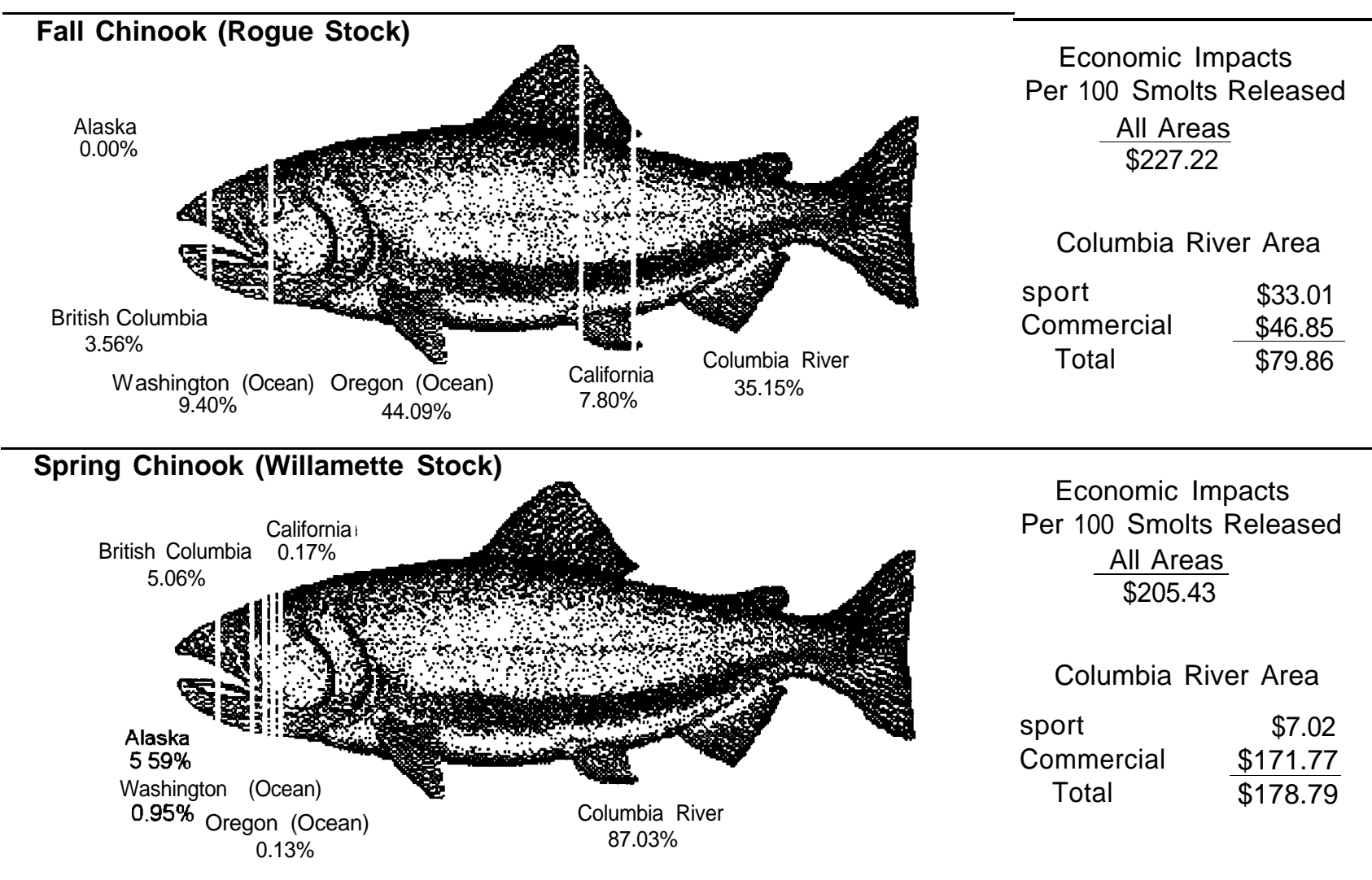

Economic Impacts

Per 100 Smolts Released

$$
\begin{array}{r}
\text { All Areas } \\
\$ 193.34
\end{array}
$$

Columbia River Area

$$
\begin{array}{lr}
\text { sport } & \$ 12.52 \\
\text { Commercial } & \$ 106.84 \\
\text { Total } & \$ 119.36
\end{array}
$$

Economic Impacts

Per 100 Smolts Released

All Areas

$\$ 275.71$

Columbia River Area

\begin{tabular}{lr} 
sport & $\$ 47.21$ \\
Commercial & $\$ 53.12$ \\
\cline { 2 - 2 } Total & $\$ 100.33$
\end{tabular}


The Expansion Project that released 57 million smolts from seven possible sites could generate $\$ 37$ to $\$ 42$ million to the lower Columbia River economy. Another $\$ 11$ million may be generated to the lower Columbia River economy by the recreational fishery, if the acclimation and release project were initiated. In total, as much as $\$ 109$ million may be generated in coastal and Columbia River communities (\$140 million at the state level) through commercial and recreational harvest by this project.

The actual economic impact of such an expanded acclimation and release project depends on many factors that are beyond the scope of straightforward economic impact analysis. Some of these factors are:

1. Effect of ocean fisheries treaty agreements. The harvestability of such an expanded program.

2. Mitigation agreements on hatchery production: numbers, species, broods. For example, at the present time, the National Marine Fisheries Service has a 197 million "cap" on smolt releases for the Columbia River system.

3. Harvest management policy and allocation agreements.

4. Environmental variability.

\section{Comparison of Costs, Ex-Vessel Revenues and Economic Income Impacts}

The acclimation and release costs on a species basis for total new releases (all sites), with or without fin/tag, range from $\$ 0.030$ per smolt for coho to $\$ 0.083$ per smolt for spring chinook (Table 7).

\section{Table 7}

Estimated Costs per Smolt for the Lower Columbia River/Youngs Bay

Terminal Fisheries Expansion Project by Species

$\begin{array}{ll}\text { OM\&R costs per released smolt w fin clipping } & \\ \text { Spring Chinook (Nov.-Feb.) } & 0.083 \\ \text { Spring Chinook (Mar.) } & 0.034 \\ \text { Coho } & 0.055 \\ \text { Fall Chinook (June-Aug.) } & 0.081 \\ \text { Total for site } & 0.061 \\ & \\ \text { OM\&R costs per released smolt w/o fin clipping } & \\ \text { Spring Chinook (Nov.-Feb.) } & 0.083 \\ \text { Spring Chinook (Mar.) } & 0.034 \\ \text { Coho } & 0.030 \\ \text { Fall Chinook (June-Aug.) } & 0.056 \\ \text { Total for site } & 0.043\end{array}$

Notes: 1. Units are dollars per smolt introduced into the acclimation and release project. 
Gillnetters in the lower Columbia River and Youngs Bay, as a result of the acclimation and release project, could expect to receive ex-vessel revenues from $\$ 19.67$ for coho to $\$ 76.22$ for spring chinook, per 100 smolts released.

The West Coast economies, from southeast Alaska to California, could receive about $\$ 193$ to $\$ 276$ per 100 smolts released. A simple arithmetic ratio between the income generated by the hatchery and the acclimation and release project may present some indication of the returns to the Pacific region of this project. It should be noted, however, that this analysis is very

dependent on the estimates provided by ODFW on fish returns and should not be viewed as an economic benefit-cost analysis.

For the lower Columbia River economies, for every dollar that is invested into the acclimation and release project, a return of $\$ 4.57$ (Rogue fall chinook) to $\$ 44.73$ (spring chinook - March release) may be expected.

At present, there is a voluntary $\$ 0.10$ per pound assessment ( $\$ 0.05$ to gillnetters and $\$ 0.05$ to processors). For this project to be self-supporting, the assessment per pound varies from four percent for spring chinook - March release to 39 percent for Rogue fall chinook.

The Expansion Project, as it is planned, may include these percentages as an indication of the efficacy of the program mix. In order for the program as it is presently planned to be self supporting, the assessment from the gillnet fishery would have to be levied at about a 17 percent to 27 percent rate (Table 8).

These assessments may be reduced if a different strategy is employed that would reduce the number of fall chinook (especially Rogue stock) and increase the number of spring chinook short acclimation period and March release.*

\begin{tabular}{|c|c|c|c|c|c|c|}
\hline & \multicolumn{5}{|c|}{$\begin{array}{c}\text { Ratios of Lower River Columbia Salmon Acclimation and Release } \\
\text { and Hatchery Costs to Ex-Vessel Revenues }\end{array}$} & \multirow[b]{2}{*}{$\begin{array}{c}\text { Oregon/Wash } \\
\text { Harvest/ } \\
\text { Acclimation anc } \\
\text { Hatchery Costs }\end{array}$} \\
\hline & $\begin{array}{l}\text { Columbia R } \\
\text { Gillnet Harvest/ } \\
\text { Acclimation } \\
\text { costs }\end{array}$ & $\begin{array}{l}\text { West Coast } \\
\text { Harvest/ } \\
\text { Acclimation } \\
\text { costs }\end{array}$ & $\begin{array}{l}\text { Oregon/Wash } \\
\text { Harvest/ } \\
\text { Acclimation } \\
\text { costs }\end{array}$ & $\begin{array}{l}\text { Columbia R. } \\
\text { Gillnet Harvest/ } \\
\text { Acclimation and } \\
\text { Hatchery Costs }\end{array}$ & $\begin{array}{c}\text { West Coast } \\
\text { Harvest/ } \\
\text { Acclimation and } \\
\text { Hatchery Costs }\end{array}$ & \\
\hline wlthout fin/tag & $17 \%$ & $6 \%$ & $7 \%$ & $192 \%$ & $77 \%$ & $85 \%$ \\
\hline with fin/tag & $27 \%$ & $10 \%$ & $12 \%$ & $202 \%$ & $81 \%$ & $89 \%$ \\
\hline
\end{tabular}

2. Gillnet harvesting costs (other than labor and net profit) in the Columbia River may average from $35 \%$ to $50 \%$ of ex-vessel revenues. The profitability and the ability to pay an assessment as high as $25 \%$ would depend on total annual salmon availability and on the expected average individual harvest. 
The returns, projected revenues, and other financial support will have to be considered in the final project. ${ }^{3}$ Year round use of acclimation pens and labor, as well as impacts on other users of returning fish, such as recreational harvesters in Oregon and Washington, may also be very important. For example, the Ocean troll and recreational fishery, as well as the Columbia River recreational fishery, may receive substantial benefits resulting from this project. If the states of Oregon and Washington charge recreational fishing in the lower Columbia River area, including Youngs Bay, a fee of $\$ 3.00$ per fish caught, it could generate $\$ 1$ million for this program, enough to offset a projected deficit between gillnetters' assessment fees and the total acclimation and release project. ${ }^{4}$ Most of these trips would be taken for the returning coho. In terms of total income generated for the lower Columbia River economy, the recreational fishery could generate the following income per 100 acclimated and released smolt:
$\$ 33$
per 100 acclimated and released
Fall Chinook - Rogue Stock
$\$ 13$ per 100 acclimated and released
$\$ 7$ per 100 acclimated and released
Fall Chinook - Upper River Brights
$\$ 47$
per 100 acclimated and released
Spring Chinook
Coho - early release

A $\$ 3.00$ fee would substantially reduce the need for a 17 percent to 27 percent gillnet fishery assessment. The argument could be made that benefits received by other fisheries (besides gillnet) are to the general public, and that general funds or other means could be used to support this project.

Similarly, other areas of the West Coast receive economic benefits (in terms of regional income and jobs) from Columbia River released salmon. If all beneficiaries of these Columbia River salmon were to pay an equal assessment, based on a percentage of the commercial exvessel value (recreationally harvested fish at the same ex-vessel value as commercially harvested fish), an overall assessment of six percent to 10 percent on all beneficiaries would be needed to support this acclimation and release program (Table 8).

A less encompassing program may be for the states of Oregon and Washington to assess beneficiaries of this program according to their use. An assessment of seven percent to 12 percent on Oregon and Washington beneficiaries would support such a program (Table 8).

The major component of the acclimation and release projects are the provision of smolts The hatchery costs may be substantial, especially capital costs. There are many historical and contractual reasons for public (and private) support of salmon propagation programs. Rearing costs in such cases may not be included. However, salmon enhancement for economic development purposes should include all rearing costs. The construction of new facilities would involve capital costs of about $\$ 50$ per pound of smolts produced. On a cost consideration basis only, if the hatchery component were also to be included in the Expansion Project, the assessment rate on Columbia River gillnet revenues would be double the expected

3. Other considerations, such as treaties and biological constraints, are not introduced in this section.

4. This is used as an example only. The legality, logistics and other possible problems with such a program are not addressed. 
gillnet revenues. If all beneficiaries were assessed an equal rate of the commercial fish exvessel value, an assessment of about 81 percent would cover the costs of hatchery and acclimation and release. A somewhat higher assessment of about 89 percent would be required if only the harvesters of Oregon and Washington were to be included (Table 8).

The significance of the ratios in Table 8 is that an acclimation and release program in the lower Columbia River area may be economically justifiable as part of a historical mitigation program to support a commercial and recreational salmon fishing industry on the Columbia River and the Pacific North American west coast. Based on recent historical survival rates from smolts to harvestable adults, a program without public financial support for rearing costs could not be expected to pay for the capital and operational costs.

When all hatchery costs are included, coho rearing is the most expensive option. If the lower Columbia River gillnetters were to support a total rearing program alone (hatchery as well as acclimation and release), the rearing costs of coho may be three times as high as the expected gillnet ex-vessel revenues.

\section{Project Feasibility}

The proposal to expand the acclimation and release project at seven new sites and the existing Youngs Bay site on the lower Columbia River is premised on several key assumptions. These are:

- The Columbia River salmon fishing industry has been an integral part of the local and state economy.

- As development on the Columbia River system took place that changed critical salmon habitat and critical water flows, mitigation agreements were made to replace affected salmon runs by other means. In most cases, this has meant artificial propagation (hatcheries).

- The acclimation and release process in the Columbia River is estimated to increase the survival of smolts to harvested adults by a factor of 1.77 for chinook and 2.33 for coho.

- There will be no legal or contractual barrier to the placement of the 57 million smolts needed for the acclimation and release project. These provided smolts will be part of the mitigation process.

- The increased survival of the acclimation and release project has the potential to increase the ex-vessel revenues received by the Columbia River gillnetters by $\$ 11$ million. This is at an estimated acclimation and release cost of about $\$ 3.5$ million. The acclimation and release project has the potential to generate about $\$ 19$ million additional to the lower Columbia River economies and about a total of \$24 million to 
the state economies of Oregon and Washington. The West Coast economy will gain an additional estimated $\$ 49$ million as a result of this project.

Clearly, the project is "feasible" if this is viewed as an accepted alternative means to produce smolts for the Columbia River dependent fisheries. If the costs of hatching and rearing the smolts are already being borne by the states of Oregon and Washington as well as by the federal government, this acclimation and release project can be used to increase the amount of fish that are available to be harvested. 


\section{R eferences}

Alaska Department of Fish and Game. Personal communication. 1995.

Alaska Seafood Marketing Institute. Personal communication. 1995.

Alaska Seafood Marketing Institute. Salmon 2000. 1992.

Anderson, James L., Department of Resource Economics, University of Rhode Island. Personal communication. February 1995.

Canadian Department of Fisheries and Oceans. Catch Statistics 1993.

Hill, Jim. Personal communication. July 1995.

Pacific Fishing. 1994 Yearbook. March 1995

Salmon Market Information Service. Currents, A Journal of Salmon Market Trends. "World Salmon Supply: Part I.' No. 4. June 1995.

Washington Farmed Salmon Commission. Salmon Primer. Bellingham, Washington. January 1995. 